\title{
Sandwich-like systems to engineer the cellular microenvironment
}

\author{
Thesis submitted by \\ José Ballester Beltrán \\ to obtain the degree of Doctor of Philosophy \\ at the Universitat Politècnica de València \\ Valencia (Spain), November 2014
}

Thesis supervisors:

Prof. Manuel Salmerón-Sánchez

Dr. Patricia Rico Tortosa 
Members of the jury:

Prof. Jonathan M. Cooper

Division of Biomedical Engineering, School of Engineering

University of Glasgow

Glasgow, UK

Prof. José Luís Gómez Ribelles

Center for Biomaterials and Tissue Engineering (CBIT)

Universitat Politècnica de Valencia

Valencia, Spain

Prof. Elisabeth Engel López

Institute for Bioengineering of Catalonia (IBEC)

Technical University of Catalonia

Barcelona, Spain

The research described in this thesis was carried out at the Center for Biomaterials and Tissue Engineering (CBIT) at Universitat Politècnica de València, University of Glasgow and Martin-Luther University Halle-Wittenberg; and partially funded by the Spanish Ministry of Education, Culture and Sports (through the FPU program AP2009-3626) and the European Research Council (through HealInSynergy 306990). 




\section{Acknowledgements}

I would like to take this opportunity to show my gratitude to all those who have shared these last years with me. In one way or another you have helped me during this process and made me to become the person I am now.

First and foremost, I would like to express my most sincere gratitude to Manuel Salmerón Sánchez for giving me the opportunity to take part of such a nice group. Thanks for your guidance and dedication during these last years. Thanks for every single opportunity and for believing in me.

I also would like to thank Patricia Rico and Myriam Lebourg for their support. It was such a pleasure to work with you. I have learnt so much from you, and not only science-related.

I would like to thank all the people from the Center for Biomaterials and Tissue Engineering, as well as from the MiMe group, for their support and advice inside and outside the lab. Specially those with whom I have worked and spent more time with: Cristina, Marco, Virginia, Cris, Alex, Vladimira... all of you have been such a great mentors and colleagues. 
I want to express my gratitude to Prof. Thomas Groth and Prof. Matthew Dalby. Thanks for giving me the opportunity to work with your groups during my internships. These experiences have been invaluable for me. Likewise I would like to thank all the people from your groups, for their hospitality during those months away from home.

I would like to thank Alberto Hernández from the Optical and Confocal Microscopy Facility at CIPF (Valencia, Spain) for his valuable assistance during the migration assays and confocal imaging.

This thesis could not have been possible without financial support. Therefore the European Research Council (ERC; HealInSynergy 306990) and FPU program (AP2009-3626) are acknowledged, as well as the support of the Networking Biomedical Research Center (CIBER-BBN) and the Spanish Ministry of Science and Innovation.

These years have been fruitful when it comes to making new friends; and not only from the laboratory but also from outside. Old and new friends, flatmates, family... Thanks to all of you ;)

Last but not least, thank you so much Luz. 




\section{Contents}

Abstract

Resumen

$\mathrm{XV}$

Resum

XIX

Abbreviations

XXIII

\section{Introduction}

1.1 Cell-protein-material interaction

1.2 Role of the culture dimensionality 7

1.3 Sandwich-like culture

2. Objectives

3. Materials and Methods

3.1 Materials

3.2 Materials fabrication

3.3 Materials characterisation

3.4 Cell culture 35

3.5 Biological characterisation

3.6 Statistical Analysis

3.7 References

4. Cell morphology and adhesion

4.2 Materials and methods

4.2.1 Materials

4.2.2 Cell culture

4.2.3 Biological characterisation

4.3 Results and discussion

4.3.1. Role of the ventral substrate in cell morphology 50

4.3.2 Effect of non-adhesive dorsal contact on cell morphology 55

4.3.3 Cell fate within sandwich culture with different dorsal stimulation 
$\begin{array}{ll}\text { 5. Cell migration } & \mathbf{7 7}\end{array}$

$\begin{array}{ll}5.1 \text { Introduction } & 79\end{array}$

$\begin{array}{ll}5.2 \text { Materials and methods } & 80\end{array}$

$\begin{array}{ll}5.2 .1 \text { Material } & 80\end{array}$

5.2.2 Cell culture $\quad 81$

5.2.3 Biological characterisation $\quad 82$

$\begin{array}{ll}5.3 \text { Results and discussion } & 82\end{array}$

5.3.1 Phenomenology of cell migration within sandwich environments $\quad 82$

5.3.2 Characterisation of the migrating cells 85

5.3.3 Ventral ECM remodelling during cell migration 90

5.3.4 Role of the ventral substrate in cell migration 92

5.3.5 Role of dorsal stimuli in cell migration 96

$\begin{array}{ll}5.4 \text { Conclusions } & 97\end{array}$

5.5 References 98

6. Induced C2C12 differentiation 103

6.1 Introduction $\quad 105$

6.2 Materials and methods 106

6.2.1 Material 106

6.2.2 Cell culture 106

$\begin{array}{ll}6.3 \text { Results and discussion } & 107\end{array}$

$\begin{array}{ll}\text { 6.3.1 Material characterisation } & 107\end{array}$

6.3.2 Initial spreading and morphology; dorsal and ventral cues108

6.3.3 Dorsal stimuli enhance myogenic differentiation $\quad 111$

6.3.4 Integrin expression and cell signalling $\quad 115$

6.3.5 Dorsal integrins and cell differentiation $\quad 119$

6.3.6 Release of paracrine factors 123

6.4 Conclusions 124

6.5 References 126 
7. Spontaneous cell differentiation

7.1 Introduction

7.2 Materials and methods

7.2.1 Material

7.2.2 Cell culture

7.3 Results and discussion

7.3.1 C2C12 differentiation

7.3.2 hMSCs differentiation

7.4 Conclusions

7.5 References

8. Conclusions 



\section{Abstract}

While most of the in vitro cultures are carried out on bi-dimensional (2D) substrates, most of the in vivo extracellular matrices are threedimensional (3D). Consequently cells behave differently on 2D substrates as a way to self-adaptation to a non-physiological environment. This fact has encouraged the development of more relevant culture conditions seeking to provide more representative models for biomedicine (e.g. cancer, drug discovery and tissue engineering) and further insights into any dimension-dependent biological mechanism. Different 3D culture systems have been established though their variability and complexity hinder their standardisation in common cell culture procedures. So, this thesis deals with the dimensionality issue in cell/material interactions and introduces sandwich-like microenvironments as a versatile tool to study cell behaviour. Cells cultured within this system use both dorsal and ventral receptors to adhere and spread, undergoing important changes with respect to the 2D cultures and approaching to 3D conditions.

Stimulation of dorsal receptors has been previously addressed by overlaying a protein gel on cells already attached on a 2D surface. Here we propose a sandwich-like system that consists of two 2D surfaces so that wider spectra of conditions can be investigated by changing the nature of the substrate (material, topography...) and the protein coatings of both ventral and dorsal sides.

Since sandwich culture provides an altered cellular adhesion compared to the traditional 2D substrates by the excitation of the dorsal receptors, changes in the intracellular signalling are expected, which 
might alter important processes such as proliferation, morphology, migration and differentiation. Hence this thesis evaluates the effect of different sandwich culture parameters in cell behaviour.

First, cell fate upon adhesion was evaluated in terms of morphology, proliferation and adhesion. Different conditions were studied such as materials with different properties or protein coatings (dorsal and ventral substrates), as well as the effect of sandwiching cells just after seeding or after been allowed to adhere to the ventral substrate. Interesting results were obtained such as the relationship between the ability of cells to reorganise the ECM with cell morphology, proliferation and adhesion, similarly as observed in 3D hydrogels (degradable vs nondegradable systems).

Then, cell migration within sandwich culture was studied by live imaging of a wound healing assay. Results revealed the key effect of both ventral and dorsal substrates in determining the migration rate as well as the migration mode used by cells. Moreover cells within the sandwich culture migrating in the wound healing assay adopted an elongated cell morphology that resembled cells migrating in other 3D systems. Beyond differences in cell morphology and migration, dorsal stimulation promoted cell remodelling of the extra-cellular matrix (ECM) over simple ventral receptor activation in traditional 2D cultures.

Finally the effect of sandwich culture on cell differentiation was evaluated. First we showed an increase in C2C12 myogenic differentiation when cultured within the sandwich system. This enhancement was shown to be dorsal stimulation dependent and related to an alteration of the 
signalling pathway and the growth factor release. To determine if sandwich culture leads only to myogenic differentiation or whether it allows differentiation to other lineages, 4 different human mesenchymal stem cells (hMSCs) lines were cultured under the same conditions. Results showed the same sandwich environment triggered different cell differentiation. This points out the importance of the microenvironment cell niche in vivo, which highly influence cell fate, and thus the need of mimicking it properly in vitro.

Overall, sandwich-like microenvironments switch cell behaviour towards 3D-like patterns, demonstrating the importance of this versatile, simple and robust approach to mimic cell microenvironments in vivo. 



\section{Resumen}

Mientras que la mayoría de los cultivos celulares in vitro son realizados en sustratos bidimensionales (2D), la mayoría de las matrices extracelulares in vivo son tridimensionales (3D). Por consiguiente, las células se comportan de manera diferente en los cultivos 2D a modo de adaptación al ambiente no fisiológico. Este hecho ha fomentado el desarrollo de condiciones de cultivo más relevantes con el fin de proporcionar modelos más representativos para la biomedicina (como por ejemplo cáncer, descubrimiento de nuevos fármacos e ingeniería de tejidos) y obtener un mayor conocimiento de los mecanismos biológicos relacionados con la dimensionalidad. Se han desarrollado distintos sistemas de cultivo 3D aunque su variabilidad y complejidad dificultan su establecimiento como procedimientos de cultivo celular comunes. Por ello esta tesis trata el problema de la dimensionalidad en las interacciones célula/material e introduce el cultivo tipo sandwich como una herramienta versátil para estudiar el comportamiento celular. Células cultivadas en este sistema utilizan tanto los receptores ventrales como los dorsales para adherirse y extenderse, experimentando cambios importantes respecto a los cultivos 2D y acercándose a condiciones 3D.

La estimulación de los receptores dorsales ha sido previamente abordada cubriendo células ya adheridas a una superficie 2D con un gel proteico. Aquí nosotros proponemos un sistema tipo sandwich que consiste en dos superficies 2D, de forma que se pueden estudiar un mayor espectro de condiciones cambiando la naturaleza del sustrato (material, topografía...) y el recubrimiento proteico, tanto del material ventral como el dorsal. 
Puesto que los cultivos tipo sandwich proporcionan una adhesión celular alterada respecto a los sustratos 2D tradicionales debido a la excitación de los receptores dorsales, se esperan cambios en las rutas de señalización intracelulares, lo que podría alterar procesos importantes como la proliferación, morfología, migración y diferenciación celular. Por ello esta tesis evalúa el efecto que diferentes parámetros del cultivo tipo sandwich tienen sobre el comportamiento celular.

Primero se evaluó la respuesta celular tras la adhesión en términos de morfología, proliferación y adhesión. Se estudiaron diferentes condiciones como materiales con diferentes propiedades o recubrimientos proteicos (en los sustratos dorsal y ventral), así como el efecto de realizar el sandwich justo después de la siembra o tras permitir una adhesión celular inicial al sustrato ventral. Se obtuvieron resultados interesantes como la relación existente entre la habilidad celular de reorganizar la matriz extracelular con la morfología, proliferación y adhesión celular, de manera similar a lo observado en hidrogeles 3D (en sistemas degradables respecto a no degradables).

A continuación se estudió la migración celular en el cultivo tipo sandwich por medio de ensayos wound healing. Los resultados revelaron el efecto clave que tanto el sustrato ventral como el dorsal tienen en el índice y modelo de migración usado por las células. Además las células migrando en el cultivo tipo sandwich presentaban una morfología alargada parecida a la de otras células migrando en sistemas 3D. Más allá de las diferencias en morfología y migración celular, la estimulación dorsal promovió el remodelado de la matriz extracelular con respecto a la simple activación de los receptores ventrales en los cultivos 2D. 
Finalmente se evaluó el efecto del cultivo tipo sandwich en la diferenciación celular. Primero mostramos un incremento en la diferenciación miogénica de células $\mathrm{C} 2 \mathrm{C} 12$ cultivadas en el sistema tipo sandwich. Dicho incremento es dependiente de la estimulación dorsal y esta relacionado con una alteración de la señalización intracelular y secreción de factores paracrinos. Para determinar si el cultivo tipo sandwich dirige la diferenciación celular únicamente al linaje miogénico o permite diferenciación hacia otros linajes, se cultivaron 4 líneas de células humanas mesenquimales bajo las mismas condiciones. Los resultados mostraron que las mismas condiciones del cultivo tipo sandwich provocaron diferente diferenciación celular. Este resultado destaca la importancia del entorno proporcionado por el nicho celular in vivo, el cual determina el destino celular, y por tanto la necesidad de imitarlo adecuadamente in vitro.

En general, el entorno ofrecido por el cultivo tipo sandwich cambia el comportamiento celular hacia patrones característicos de sistemas 3D, demostrando la importancia de esta aproximación simple y versátil para imitar entornos celulares in vivo. 



\section{Resum}

Mentre que gran part dels cultius cel-lulars in vitro es realitzen en substrats bidimensionals (2D), la majoria de les matrius extracel-lulars in vivo tenen una estructura tridimensional (3D). Com a conseqüència, les cèl-lules es comporten de manera diferent en el cultius 2D davant respostes d' adaptació a l'ambient no fisiològic. Açò ha fomentat el desenvolupament de cultius més realistes amb la finalitat de proporcionar models més representatius per a la biomedicina (com per exemple càncer, descobriment de nous fàrmacs i enginyeria de teixits) i obtenir un millor coneixement del mecanismes biològics relacionats amb la dimensionalitat. S'han desenvolupat diferents sistemes de cultiu 3D encara que la seua variabilitat i complexitat dificulten el seu establiment com a procediments de cultius cel-lulars comuns. Per este motiu esta tesi tracta el problema de la dimensionalitat en les interaccions cèl·lula/material e introduix el cultiu tipus sandwich com a una ferramenta versàtil per a estudiar el comportament cel-lular. Cèl-lules cultivades en este sistema utilitzen tant els receptors ventrals com els dorsals per a adherir-se y estendre's, experimentant canvis importants respecte als cultius 2D y aproximant-se a les condicions 3D.

L'estimulació del receptors dorsals ha sigut prèviament abordada cobrint les cèl-lules ja adherides a una superfície 2D amb un gel proteic. Ací nosaltres proposem un sistema tipus sandwich que consistix en dos superfícies 2D, de manera que permet estudiar un ampli espectre de condicions canviant la natura del substrat (material, topografia...) i el recobriment proteic, tant del material ventral com del dorsal. 
Ja que els cultius tipus sandwich proporcionen una adhesió cel·lular alterada respecte al substrats 2D tradicionals degut a l'excitació dels receptors dorsals, s'esperen canvis en les rutes de senyalització intracel-lulars que podrien alterar processos importants com la proliferació, morfologia, migració i diferenciació cel·lular. Per això esta tesi avalua també l'efecte que diferents paràmetres del cultiu tipus sandwich tenen sobre el comportament cel·lular.

Primer es va avaluar la resposta cel·lular en quant a morfologia, proliferació i adhesió. Es van estudiar diferents condicions com materials amb propietats diferents o recobriments proteics (en els substrats dorsal i ventral), així com l'efecte de realitzar el sandwich just després de la sembra o després de permetre l'adhesió cel-lular inicial al substrat ventral. Es van obtenir resultats interesants com la relació existent entre la habilitat cel-lular de reorganitzar la matriu extracel-lular amb la morfologia, proliferació i adhesió cel·lular, similarment al que s'observa en hidrogels 3D (en sistemes degradables respecte a no degradables).

A continuació es va estudiar la migració cel·lular en el cultiu tipus sandwich mitjançant assajos wound healing. Els resultats revelaren l'efecte clau que tant el substrat ventral com el dorsal tenen en l'índex i model de migració cel·lular. A més, les cèl-lules migrant en el cultiu tipus sandwich presentaren una morfologia allargada pareguda a la observada en altres cèl-lules cultivades en sistemes 3D. Més enllà de les diferències en morfologia i migració cel-lular, l’estimulació dorsal va promoure el remodelat de la matriu extracel-lular en comparació amb la simple activació dels receptors ventrals en cultius 2D. 
Finalment es va avaluar l'efecte del cultiu tipus sandwich en la diferenciació cel·lular. Primer s'observà un increment en la diferenciació miogènica de cèl-lules $\mathrm{C} 2 \mathrm{C} 12$ quan es cultivaren en el sistema tipus sandwich. Aquest increment es dependent de l'estimulació dorsal i està relacionat amb una alteració de la senyalització cel·lular i la secreció de factors paracrins. Per a determinar si el cultiu tipus sandwich dirigix la diferenciació cel·lular únicament al llinatge miogènic o permitix la diferenciació cap a altres llinatges, es van cultivar 4 línies de cèl-lules humanes mesenquimals diferents en les mateixes condicions. Els resultats mostraren que les mateixes condicions de cultiu provocaren diferent diferenciació cel-lular. Aquest resultat destaca la importància de l'entorn proporcionat pel nínxol cel·lular in vivo, que determina el destí cel·lular i, per tant, la necessitat d'imitar-lo adequadament in vitro.

En general, l'entorn oferit pel cultiu tipus sandwich canvia el comportament cel-lular cap a patrons característics dels sistemes 3D demostrant la importància que aquesta aproximació simple i versàtil té per a imitar entorns cel·lulars in vivo. 



\section{Abbreviations}

AFM Atomic force microscopy

BrdU 5-bromo-2'-deoxyuridine

BSA Bovine serum albumin

Col Collagen I

DAPI 4',6-diamidino-2-phenylindole

DMEM Dulbecco's modified Eagle's medium

DPBS Dulbecco's Phosphate Saline Buffer

ECM Extracellular matrix

FN Fibronectin

HEPES (4-(2-hydroxyethyl)-1-piperazineethanesulfonic acid)

MATERIALa $\rightarrow$ aligned fibers of the MATERIAL

$M A T E R I A L f i l m \rightarrow$ flat film of the MATERIAL

MATERIALspc $\rightarrow$ MATERIAL spin-coated

MMP Matrix metalloproteinase

MSCs Mesenchymal stem cells

hMSCs Human mesenchymal stem cells

PAGE Polyacrylamide gel electrophoresis

PBA Poly (butyl acrylate)

PEA Poly (ethyl acrylate)

PHA Poly (hexyl acrylate)

PLLA Poly-L-lactic acid

PMA Poly(methyl acrylate)

SDS Sodium Dodecyl Sulfate

SEM Scanning electron microscopy

VN Vitronectin 

Chapter 1. Introduction 



\subsection{Cell-protein-material interactions}

\section{Cell-protein-material interface}

Cell culture procedures are now well stablished in 2D systems in order to study for instance cell biology, drug discovery and cancer development. The first step of any cell culture is cell adhesion to the material surface. Living cells cannot interact directly with synthetic materials, but they readily attach to the extracellular matrix (ECM) proteins adsorbed on the substrate coming from physiological fluids in vivo or culture medium in vitro. ${ }^{1}$ These adsorbed matrix proteins can be recognised by cell surface receptors, such as integrins, that provide trans-membrane links between the ECM and the actin cytoskeleton. ${ }^{2}$ Afterwards, integrins cluster and develop focal adhesion (FAs) complexes that anchorage cells to the material surface (figure 1.1). Focal adhesions are supramolecular complexes that contain structural proteins (such as vinculin, paxillin or talin) and signalling molecules (such as focal adhesion kinase, FAK). ${ }^{2,3}$

A

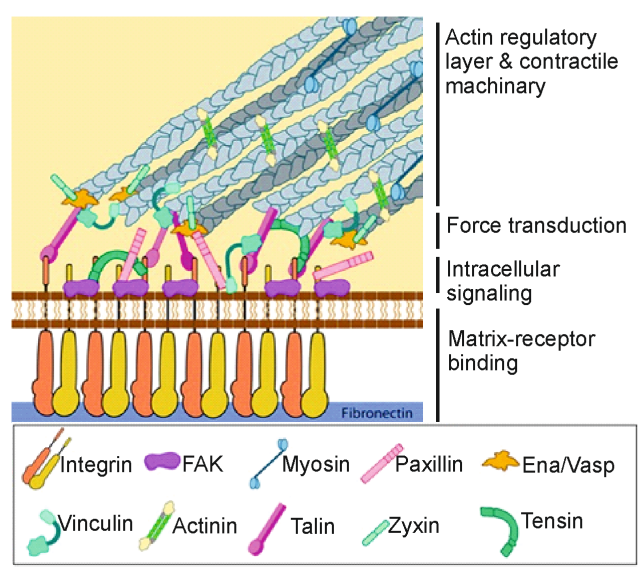

B

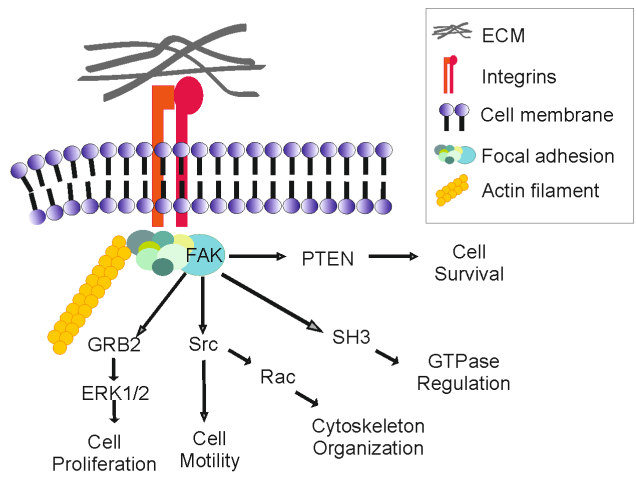

Figure 1.1. Focal adhesion complexes. (A) Schematic representation of focal adhesions structure and (B) the signalling pathways modulated upon cell adhesion. Adapted from Mechanobiology Institute, National University of Singapore $^{7}$ and reference 8.

FAK signalling is a key pathway linking cell adhesion to cell fate (cell proliferation, cell motility and cytoskeleton reorganisation among others) since it is a main actor linking cell adhesion with key signalling pathways such as ERK1/2, Rac and PTEN.4-6 Thus, the initial cell-material interaction is a complex multistep process consisting of early events (such 
as adsorption of proteins followed by cell adhesion and spreading) which will determine late events (cell growth, differentiation, proliferation etc.) (figure 1.1).

Since early events of cell adhesion will determine cell fate, the study of the relationship between material properties, adsorbed protein layers and cell adhesion becomes essential to understand the whole process and control cell fate.

Even if cells cannot interact directly with the material surface, it is known that cells response to different surface properties such as chemistry, topography and mechanics. ${ }^{9,} 10$ Most importantly, the surface properties of the materials determine the protein adsorption in terms of conformation, surface density and strength of interaction, what will influence the cell response and eventually determine the biocompatibility of the system (figure 1.2). ${ }^{11}$
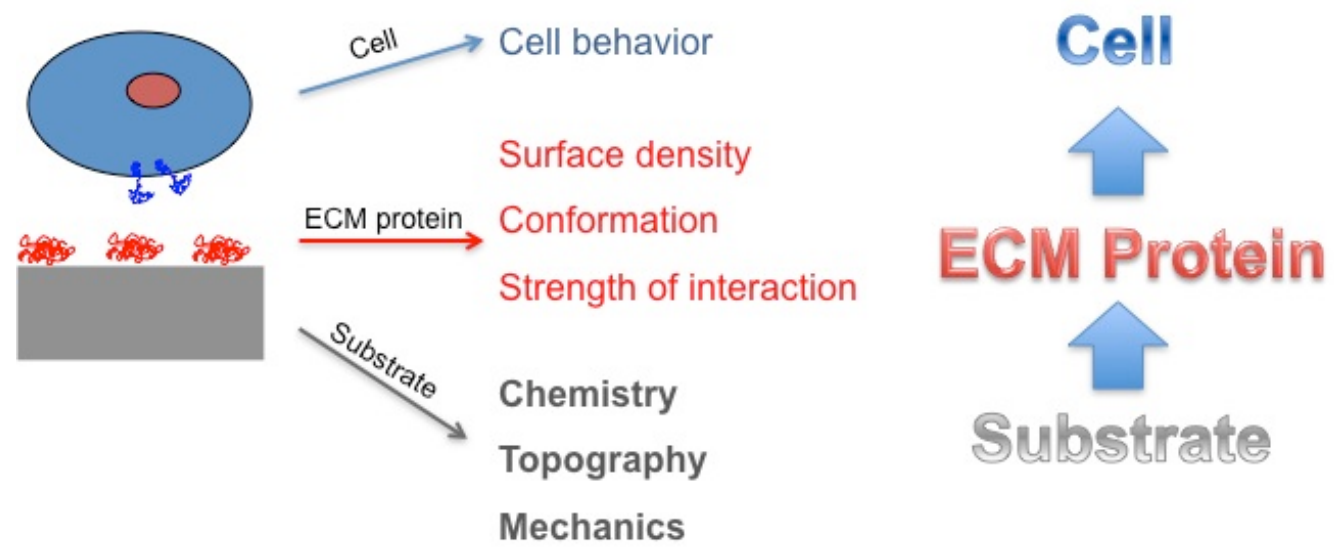

Figure 1.2. Cell-protein-material interface. Substrate properties modulate protein adsorption and thus cell behaviour.

Proteins have different types of domains (cell binding, growth factors binding, protein-protein interaction...). The importance of protein conformation on material surfaces relies basically in the fact that, according to the conformation of the protein upon adsorption, some protein domains will be exposed whereas some will be hidden. The degree of exposure of each domain will determine the specificity of integrin- 
mediated adhesion. Integrins are a large family of transmembrane proteins that exist as two non-covalently bound $\alpha / \beta$ subunits, which pair to form heterodimers. Different combinations can be formed though not all combinations are possible. Besides, different integrins can bind to the same protein (albeit with different afinities) and also one specific integrin can bind to different proteins (figure 1.3), showing the complexity of the process. $^{12}$

A

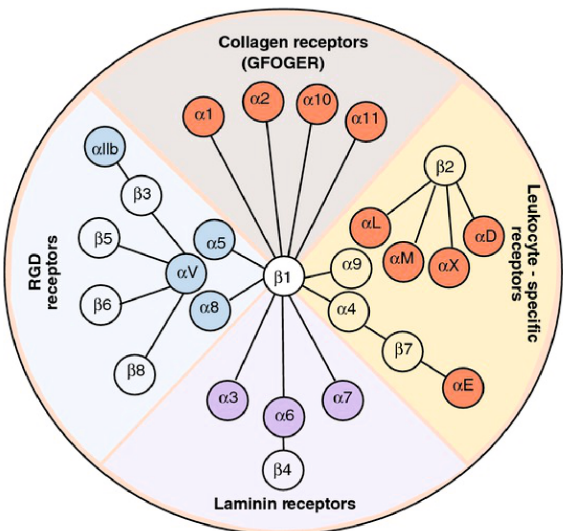

B

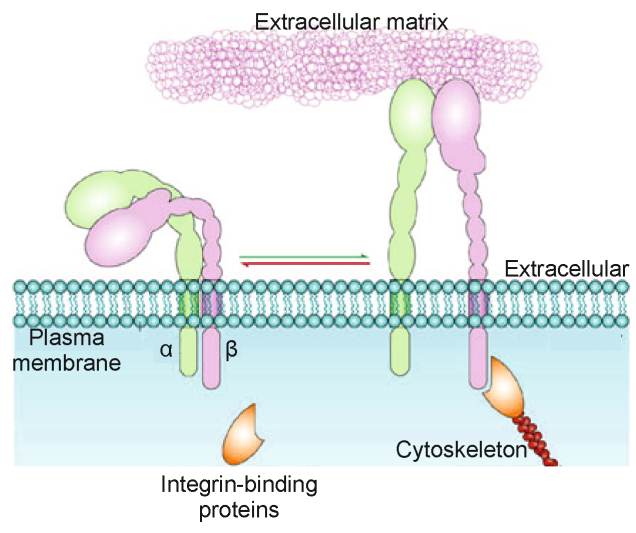

Figure 1.3. Integrins. (A) Representation of the integrin family and their ligands. (B) Integrin activation upon integrin-ECM interaction. Adapted from reference 12 and 13 respectively.

Integrins are usually in the cell membrane in an inactivated state and become activated upon ligand binding. This leads to a conformational change of the cytoplasmic domain and to the generation of tight focal adhesions which promote assembly of actin filaments (figure 1.3). These actin filaments can be reorganised into larger stress fibers leading to further integrin clustering and enhanced matrix binding by the formation of focal adhesion complexes. ${ }^{14}$ As mentioned, focal adhesions are not only formed by structural proteins but also by signalling proteins making possible the transmission of signals both outside-in and inside-out the cell. ${ }^{15}$ Cell adhesion is therefore a dynamic process influenced at different levels. ${ }^{9,10,12}$ 


\section{Role of surface properties on protein adsorption}

Reproducing characteristics of the ECM (such as the presentation of celladhesive motifs or protease-degradable cross-links) is extremely important in regenerative medicine since could allow the control of the cellular responses. ${ }^{16,17}$ Fibronectin (FN) is one of the most studied ECM proteins due to its abundance in the human body and to its role in wound healing, embryogenesis, cell attachment, etc. ${ }^{18}$ In vivo, fibronectin is assembled into an insoluble fibrillar matrix in a complex cell-mediated process. ${ }^{19}$ To do this, cells bind soluble dimers of FN by $\alpha_{5} \beta_{1}$ integrin receptors on the cell surface and stretch fibronectin by pulling on their fibronectin-bound integrin receptors, which partially unfolds the fibronectin ligand, thus unmasking cryptic fibronectin-binding sites and allowing nearby fibronectin molecules to associate. This fibronectinfibronectin interaction enables the soluble, cell-associated fibrils to branch and stabilize into an insoluble fibronectin matrix.

Reproducing this FN matrix in vitro needs complex procedures. ${ }^{20-23}$ However our group reported a family of acrylates that, by small changes in chemistry, can spontaneously trigger FN fibrillogenesis in a process that has been called "material-driven fibronectin fibrillogenesis" (figure 1.4). ${ }^{24}$ This difference in protein conformation has been shown to be related to different exposure of cell binding domains triggering different cell response in terms of adhesion, contractiltiy, differentiation and matrix degradation. ${ }^{25-28}$

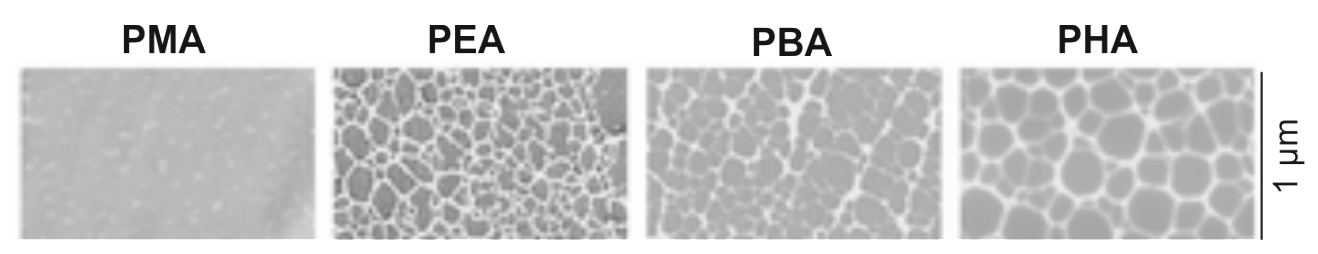

Figure 1.4. FN conformation on the polymer family as observed by the phase magnitude in atomic force microscopy (AFM). Poly (methyl acrylate), poly (ethyl acrylate), poly (buthyl acrylate) and poly (hexyl acrylate) materials are shown (PMA, PEA, PBA and PHA respectively). ${ }^{29}$ 
Topography has also been shown to be able to trigger different protein conformation. Having the material as a fiber or with high roughness lead to different fibronectin conformation and degree of domain exposure when compared to the control flat substrate, which consequently lead to different cell fate. ${ }^{30,31}$ Additionally, hydrophobocity has been related to the content of protein density adsorbed on the surface of the material and its conformation, leading to different cell fate. ${ }^{32}$ Similarly though less studied, stiffness has been shown to determine protein adsorption and conformation. ${ }^{33}, 34$ So, material properties play a key role in cell fate by influencing protein adsorption. Consequently, its role in cell behaviour must be studied.

\subsection{Role of the culture dimensionality Pshysiological relevance in cell culture}

Cell culture has been commonly carried out on 2D substrates, becoming an important and necessary tool to understand cell physiology under controlled culture conditions in vitro. However, cells cultured on a 2D surface adhere and spread freely in the horizontal plane but have no support for spreading in the z-dimension, thus adopting a flat morphology. As a consequence cells are forced to adopt an apical-basal polarity which is unnatural for most cells. These unnatural environment triggers changes in cell behaviour as a way to self adaptation to the 2D environment and directly impacts cell fate. Actually, not only cell flattening but also the degree of cell spreading and the geometric shape (e.g. circular versus starshaped, cuboidal versus elongated) can influence their fate. ${ }^{35-38}$ Hence, results otained by 2D cell cultures are not always reproducible in vivo. Cell culture systems able to better mimic the in vivo environment are therefore desired expecting cells to behave more similarly as in vivo so that more reliable results might be obtained. ${ }^{39}$

Cell culture procedures were therefore adapted to better mimic specific tissues. For example, the epithelium is our natural barrier against external pathogens (bacteria, fungus, pollution...) by covering all the body. Thus, the epithelium is a polarized tissue where the dorsal side of the cells is in direct contact with the atmosphere. However, the epithelium used to be studied by growing cells on artificial substrates immersed in culture 
medium where gases are poorly soluble and particles can denature. As a consequence, alternative methods allowing direct cell contact to the test atmosphere were developed such as roller bottles and rocking platforms. Finally cell cultures were raised to the air-liquid interface..$^{40}$ As a result, cell behaviour became closer to the in vivo and this is the reason why nowadays the determination of skin corrosion and irritation can be checked by validated air-liquid interface systems in vitro (OECD TGs 431 and 439$)^{41}$ and some bioengineered grafts are close to the clinical application. ${ }^{42,43}$ Similarly, endothelium covers blood vessels internally. So, endothelial cells face dorsally the lumen of the blood vessels and are subjected to blood shear stress. The introduction of flow stress in in vitro 2D cultures showed important changes. For example, physiological shear stress cause cell alignment similar as in vivo and triggered various functional responses such as the activation of receptors and the secretion of vaso-active substances. ${ }^{44}$ Thus, the stimulation of the dorsal receptors increase the angiogenic and vasculogenic potential resulting in a closer in vivo behaviour. 45,46

However, the natural habitat of most living cells is a threedimensional (3D) ECM that completely surrounds them. For this case, cell culture procedures got closer to in vivo environments basically by using 3D culture systems. The first attempt to seed cells in a 3D culture was carried out by Paul Weiss in 1959. He observed fibroblasts cultured in a blood plasma clot varied in shape from stellate to bipolar depending upon the orientation of the fibrous network of the clot (figure 1.5). This observation lead to emphasize the dynamic interaction between cells and their physical environment showing the role of dimensionality in cell behaviour. ${ }^{47}$ Although this important observation was showed during the development of the cell culture procedures, 2D cell cultures became standard for most research purposes due to the easiness of the procedure, the lower price and the development of new and easy techniques for its characterisation. 


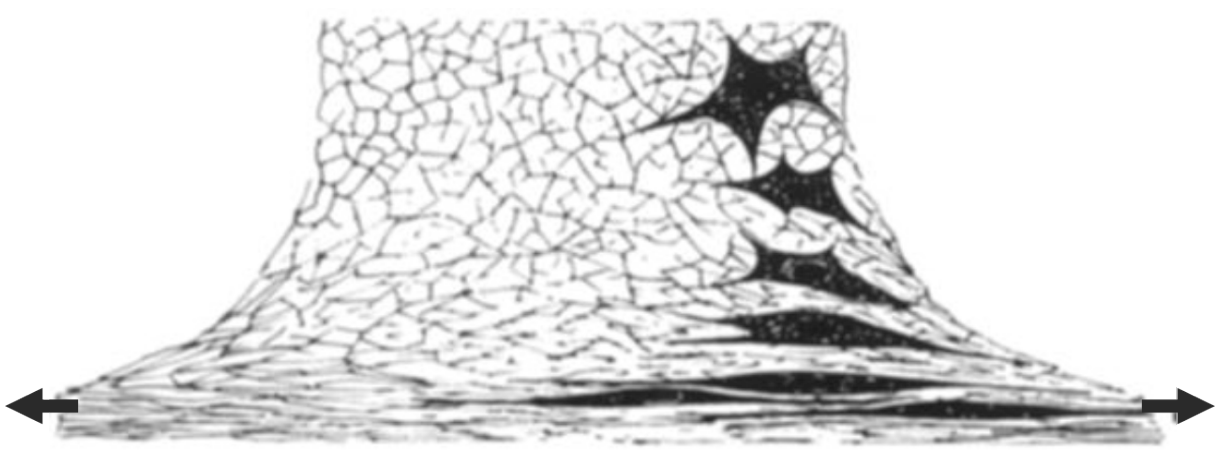

Figure 1.5. Fibroblast morphology (in black) when seeded in a stretched blood clot. As can be seen in the figure, different matrix conditions lead to different cell morphology. Adapted from reference 47.

The distribution of cell receptors anchored to the ECM on the traditional 2D cultures highly differs from that observed in vivo and is thought to be one of the key causes of the different cell behaviour since integrins trigger multiple signalling pathways modulating important processes (figure 1.1). ${ }^{48,49}$ 3D systems allow cells to bind to the ECM similarly as in vivo thus providing a similar stimuli. Due to the nature of the system cell adhesion and spreading greatly differs on 2D and 3D cultures. So it is not surprising that integrin localization and quantity differ between 2D and 3D cultures, ${ }^{50}, 51$ as well as cell behaviour, supporting the hypothesis that the different outside-in signalling might be the cause of the different cell fate. Cell-protein-material interaction plays, as in 2D substrates, a key role in cell fate though its effect in this new dimensionality should be better characterised. 


\section{Cell behaviour on 2D vs 3D cultures}

Given the difficulty of mimicking the different in vivo extracellular matrix, different complex 3D culture systems have been studied such as hydrogels, scaffolds, stacked multi cells layers and spheroids.52-55 Important knowledge has arisen from these cultures. For example, chondrocytes dedifferentiate when cultured on 2D substrates but regain their physiological form and function (including cell shape and the expression of cartilaginous markers) when embedded in a 3D agarose gel. ${ }^{56}$ Similarly, when embedded in a 3D environment, hepatocytes recover the functions lost during a 2D culture and mammary epithelial cells assemble into acinar structures with a de novo produced basement membrane. ${ }^{57-59}$ Interestingly, mammary epithelial cell acini and tubule formation were found to occur only in floating gels but not when gels remained attached to the bottom of the dish (where, as a consequence, there is an increase in mechanical properties). ${ }^{58,60,61}$ This suggests that materials properties are also sensed in 3D culture systems and, most importantly, shows the influence of new properties typical of this new dimensionality that cannot be studied on the traditional 2D cultures.

Due to these promising results 3D cultures are nowadays being increasingly used in the field of cancer research and drug development. ${ }^{39}$ For example cancer cells have been shown to turned to non-cancerous phenotype cells when the $\beta_{1}$ integrin is specifically blocked by antibodies, but strikingly only when cultured in 3D cultures. ${ }^{62}$ Another important result was found out when the protein degratation machinary of cancer cells was blocked in order to hinder their migration (and thus metastasis) since these cancer cells overcame this treatment by switching to an amoeba-like migration by squeezing through gaps in the matrix without the need of matrix degradation. ${ }^{52}$ This result explained the unsuccess of pharmacological compounds designed to hinder metastasis by blocking this degradation machinary and stress the importance of studying cell behaviour in 3D systems. 


\section{Working with 3D culture systems}

Unfortunately, differences inter- and even intra- 3D systems as well as the difficulty in having reliable 2D controls hinder identifying and understanding the key features in 3D cell cultures. This results in studies of cell fate in 3D systems that rarely compare among different 3D systems or with the traditional 2D substrate.

Several parameters have been shown to play an important role in the 3D cell culture such as (i) the physical properties, ${ }^{63}$ (ii) the pore size of the 3D system, ${ }^{52}$ (iii) the diffusion of nutrients, ${ }^{64}$ (iv) the degradability of the culture system ${ }^{65}$ and (vi) the nature of the components (i.e. PEG hydrogels which should be modified with adhesion domains in order to permit cell adhesion versus cell-derived matrices) ${ }^{66}$ among others. Choosing the correct system for each specific study is therefore essential to get reliable results though the wide variety difficults this process. Besides not all the processes can be studied by all the systems. For example, the effect of tensile deformations cannot be studied in fibrous 3D tissues since the force transmitted to the cell depends on the scale and organisation of the matrix fibers relative to that of the cell, as well as whether the cell is directly bound and/or physically constrained by the material. ${ }^{67}$

Additionally it should be taken into account that 3D systems are usually not easy to handle and, most importantly, current and easy experimental procedures on 2D substrates cannot be easily established for $3 \mathrm{D}$ cultures. For example there is a lack of proper quantitative methods for analysis of migration rates in 3D environments, protein/RNA extractions might be hindered by the nature of the system likewise colorimetric and staining procedures.

Finally, we shouldn't oversimplify the 2D-3D issue into a single difference between two states but identify the concrete features of each experimental setting to understand why cell behaviour differ in 3D culture from the more traditional 2D settings. However, getting reliable controls from 3D systems usually difficults this process. 


\subsection{Sandwich-like culture}

\section{Sandwich-like culture as a link between 2D and 3D systems}

3D cultures, by providing extra ECM-integrin stimulation, trigger a change in cell signalling pathways and close cell behaviour towards the in vivo. However, as commented before, working with 3D systems has some limitations. Thus, we hypothesize that sandwiching cells between two 2D surfaces might modify cell behaviour in a similar way since cells are not only adhering and receiving stimuli from the ventral side (like on 2D substrates) but also from the dorsal side (figure 1.6). Hence, as explained before for the endothelial cells cultured under shear-stress, the excitation of both ventral and dorsal receptors will trigger a signalling pathway which may differ from the 2D.

A

B

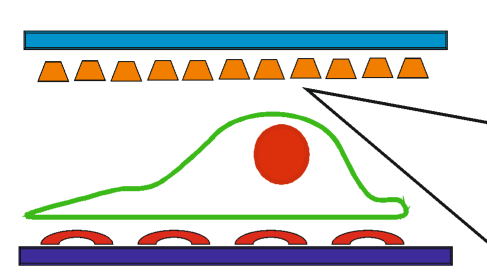

Dorsal substrate

Ventral substrate

$\square$ Dorsal protein

Ventral protein

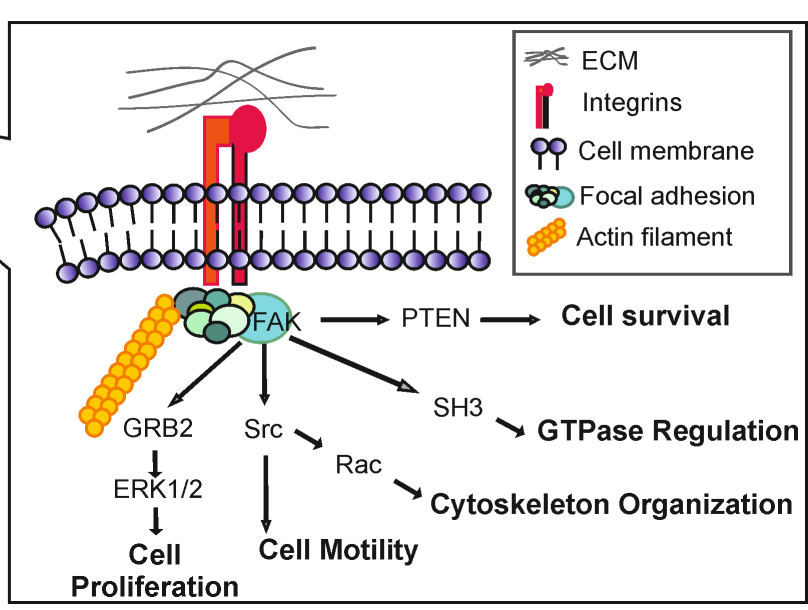

Figure 1.6. Schematic representation of the sandwich culture and its triggered cell signalling.

This suggested approach is therefore similar to other systems such as the stacked multi cell layers system or the sandwich culture formed by overlaying cells with a gel. However, some technical differences should be noticed which can be advantageous and used to deeper study some aspects of cell fate. For example, our approach allows the use of a wide range of substrates (ventral and dorsal) with different properties such as chemistry, topography or protein adsorption under well controlled conditions, what is not easy in other 3D systems. So this sandwich-like 
system could be used to study some parameters that cannot be easily studied by other systems and as an alternative method to corroborate results obtained from other systems.

Besides, due to the nature of the system which is based on 2D substrates, some technical advantages can be achieved from other systems. For instance, protein/RNA extraction can be performed similarly as for 2D substrates as well as microscope imaging if transparent substrates are chosen.

\section{Relevance of the sandwich-like culture}

Previous studies of sandwich culture comprehend mainly the culture of hepatocytes in a collagen-based sandwich. It was seen that hepatocytes cultured on a single layer of collagen gel ceased albumin secretion but could recover their functionality when overlaid with a second layer of collagen gel (which will gelified during the culture). So it was soon suggested that this culture system configuration more closely mimics the hepatocytes' in vivo environment and provides a simple method for their long-term maintenance. ${ }^{68}$ Further studies were then carried out in order to characterise this sytem and its suitability as a model to study in vitro toxicity and drug-drug interaction studies. ${ }^{69-72}$ Due to the good results, overlaying hepatocytes with a film of gel is now a common procedure to study drug toxicity in vitro.

There are also some studies evaluating for example the morphology of fibroblast when cultured between 2 polyacrylamide films, the branching of endothelial cells or cell differentiation. ${ }^{73-76}$ These few works show a dramatic change in respect to the 2D culture including changes in cell morphology and an increase in cell differentiation. Besides they point out the cell adhesion to the dorsal substrate as the process triggering changes in signalling pathways (e.g. calcium signalling) that afterwards lead to changes in cell fate. Sandwich culture has therefore the potential to recapitulate cell behaviour in a closer 3D environment. Unfortunately and even the promising results shown in these works, there is a lack of continuity and thus of deep investigations. 
Understanding how cells interact in vivo with natural 3D matrices, which furthermore can vary in composition depending on the tissue of interest, is necessary for the rational development of optimal cultures for tissue engineering. Consequently, further studies of sandwich cultures to better characterise the system and understand how substrate properties can influence cell fate is of great interest for biomedicine applications.

\subsection{References}

1. Anselme K. Osteoblast adhesion on biomaterials. Biomaterials. 2000;21:667.

2. Hynes RO. Integrins: bidirectional, allosteric signaling machines. Cell. 2002;110:673.

3. García AJ. Get a grip: integrins in cell-biomaterial interactions. Biomaterials. 2005;26:7525.

4. Mitra SK, Hanson DA, Schlaepfer DD. Focal adhesion kinase: in command and control of cell motility. Nat Rev Mol Cell Biol. 2005;6:56.

5. Schlaepfer DD, Hauck CR, Sieg DJ. Signaling through focal adhesion kinase. Prog Biophys Mol Biol. 1999;71:435.

6. Zhao X, Guan JL. Focal adhesion kinase and its signaling pathways in cell migration and angiogenesis. Adv Drug Deliv Rev. 2011;63:610.

7. Focal Adhesion organization. In MBInfo Wiki, Retrieved 3/26/2014 fromhttp://www.mechanobio.info/figure/figure/1384243372096 .jpg.html

8. Ballester-Beltrán J, Lebourg M, Salmerón-Sánchez M. Dorsal and ventral stimuli in sandwich-like microenvironments. Effect on cell differentiation. Biotechnol Bioeng. 2013;11:3048.

9. Wong JY, Leach JB, Brown XQ. Balance of chemistry, topography, and mechanics at the cell-biomaterial interface: Issues and challenges for assessing the role of substrate mechanics on cell response. Surf Sci. 2004;570:119.

10. Engler AJ, Sen S, Sweeney HL, Discher DE. Matrix elasticity directs stem cell lineage specification. Cell. 2006;126:677. 
11. García AJ. Interfaces to Control Cell-Biomaterial Adhesive Interactions. Adv Polym Sci. 2006;203:171.

12. Barczyk M, Carracedo S, Gullberg D. Integrins. Cell Tissue Res. 2010;339:269.

13. Kinbara K, Goldfinger LE, Hansen M, Chou FL, Ginsberg MH. Ras GTPases: integrins' friends or foes?. Nat Rev Mol Cell Biol. 2003;4:767.

14. Giancotti FG, Ruoslahti E. Integrin signaling. Science. 1999;285:1028.

15. Zent R, Pozzi A. Integrin Structure and Function. In: CellExtracellular Matrix Interactions in Cancer, chapter 2. Springer Science+Business Media. 2010:19

16. Petrie TA, Raynor JE, Dumbauld DW, Lee TT, Jagtap S, Templeman KL, Collard DM, García AJ. Multivalent integrin-specific ligands enhance tissue healing and biomaterial integration. Sci Transl Med. 2010;2:45ra60.

17. Lutolf MP, Gilbert PM, Blau HM. Designing materials to direct stemcell fate. Nature. 2009;462:433.

18. Grinnell F. Fibronectin and wound healing. J Cell Biochem. 1984;26:107.

19. Mao Y, Schwarzbauer JE. Fibronectin fibrillogenesis, a cellmediated matrix assembly process. Matrix Biol. 2005;24:389.

20. Sakai K, Fujii T, Hayashi T. Cell-free formation of disulfide-bonded multimer from isolated plasma fibronectin in the presence of a low concentration of $\mathrm{SH}$ reagent under a physiological condition. J Biochem. 1994;115:415.

21. Vartio T. Disulfide-bonded polymerization of plasma fibronectin in the presence of metal ions. J Biol Chem. 1986;261:9433.

22. Peters DMP, Chen Y, Zardi L, Brummel S. Conformation of Fibronectin Fibrils Varies: Discrete Globular Domains of Type III Repeats Detected. Microsc Microanal. 1998;4:385.

23. Volberg T, Ulmer J, Spatz J, Geiger B. Chemical and Mechanical Micro-Diversity of the Extracellular Matrix. In: IUTAM Symposium on Cellular, Molecular and Tissue Mechanics. IUTAM Bookseries. Springer Netherlands. 2010;16:69 
24. Rico P, Rodríguez Hernández JC, Moratal D, Altankov G, Monleón Pradas M, Salmerón-Sánchez M. Substrate-induced assembly of fibronectin into networks: influence of surface chemistry and effect on osteoblast adhesion. Tissue Eng Part A. 2009;15:3271.

25. Llopis-Hernández V, Rico P, Moratal D, Altankov G, SalmerónSánchez M. Role of material-driven fibronectin fibrillogenesis in protein remodeling. Biores Open Access. 2013;2:364.

26. Llopis-Hernández V, Rico P, Ballester-Beltrán J, Moratal D, Salmerón-Sánchez M. Role of surface chemistry in protein remodeling at the cell-material interface. PLoS One. 2011;6:e19610.

27. Salmerón-Sánchez M, Rico P, Moratal D, Lee TT, Schwarzbauer JE, García AJ. Role of material-driven fibronectin fibrillogenesis in cell differentiation. Biomaterials. 2011;32:2099.

28. Cantini M, González-García C, Llopis-Hernández V, SalmerónSánchez M. Material-Driven Fibronectin Fibrillogenesis. In: Proteins at Interfaces III State of the Art, chapter 22. ACS Symposium Series. 2012;1120:471

29. Guerra NB, Gonzalez-Garcıa C, Llopis V, Rodriguez-Hernandez JC, Moratal D, Rico P, Salmeron-Sanchez M. Subtle variations in polymer chemistry modulate substrate stiffness and fibronectin activity. Soft Matter 2010;6:4748

30. Ballester-Beltrán J, Rico P, Moratal D, Song W, Mano JF, SalmerónSánchez M. Role of superhydrophobicity in the biological activity of fibronectin at the cell-material interface. Soft Matter, 2011;7:10803

31. Ballester-Beltrán J, Cantini M, Lebourg M, Rico P, Moratal D, García AJ, Salmerón-Sánchez M. Effect of topological cues on materialdriven fibronectin fibrillogenesis and cell differentiation. J Mater Sci Mater Med. 2012;23:195.

32. Wei J, Igarashi T, Okumori N, Igarashi T, Maetani T, Liu B, Yoshinari M. Influence of surface wettability on competitive protein adsorption and initial attachment of osteoblasts. Biomed Mater. 2009;4:045002. 
33. Brizuela Guerra N, González-García C, Llopis V, RodríguezHernández JC, Moratal D, Rico P, Salmerón-Sánchez M. Subtle variations in polymer chemistry modulate substrate stiffness and fibronectin activity. Soft Matter 2010;6:4748.

34. Hsu S-H, Kao Y-C. Biocompatibility of poly(carbonate urethane)s with various degrees of nanophase separation. Macromol Biosci 2005;5:246.

35. Brock A, Chang E, Ho CC, LeDuc P, Jiang X, Whitesides GM, Ingber DE. Geometric determinants of directional cell motility revealed using microcontact printing. Langmuir. 2003;19:1611.

36. Théry M, Racine V, Piel M, Pépin A, Dimitrov A, Chen Y, Sibarita JB, Bornens M. Anisotropy of cell adhesive microenvironment governs cell internal organization and orientation of polarity. Proc Natl Acad Sci U S A. 2006;103:19771.

37. Thomas CH, Collier JH, Sfeir CS, Healy KE. Engineering gene expression and protein synthesis by modulation of nuclear shape. Proc Natl Acad Sci U S A. 2002;99:1972.

38. McBeath R, Pirone DM, Nelson CM, Bhadriraju K, Chen CS. Cell shape, cytoskeletal tension, and RhoA regulate stem cell lineage commitment. Dev Cell. 2004;6:483.

39. Abbott A. Cell culture: biology's new dimension. Nature. 2003;424:870.

40. Voisin C, Aerts C, Houdret JL, Tonnel AB. Effect of $\mathrm{NO}_{2}$ on alveolar macrophages. In: Reactions bronchopulmonaires aux pollutants atmospheriques. Paris: INSERM; 1974:273

41. OECD Guidelines for the Testing of Chemicals, Section 4 Health Effects. ISSN :2074-5788 (online) DOI :10.1787/20745788

42. Braziulis E, Diezi M, Biedermann T, Pontiggia L, Schmucki M, Hartmann-Fritsch F, Luginbühl J, Schiestl C, Meuli M, Reichmann E. Modified plastic compression of collagen hydrogels provides an ideal matrix for clinically applicable skin substitutes. Tissue Eng Part C Methods. 2012;18:464. 
43. Schiestl C, Biedermann T, Braziulis E, Hartmann-Fritsch F, Böttcher-Haberzeth S, Arras M, Cesarovic N, Nicolls F, Linti C, Reichmann E, Meuli M. Skingineering II: transplantation of largescale laboratory-grown skin analogues in a new pig model. Pediatr Surg Int. 2011 Mar;27(3):249-54.

44. Zhang B, Peticone C, Murthy SK, Radisic M. A standalone perfusion platform for drug testing and target validation in micro-vessel networks. Biomicrofluidics. 2013;7:44125.

45. Metallo CM, Vodyanik MA, de Pablo JJ, Slukvin II, Palecek SP. The response of human embryonic stem cell-derived endothelial cells to shear stress. Biotechnol Bioeng. 2008;100:830.

46. McCloskey KE, Smith DA, Jo H, Nerem RM. Embryonic stem cellderived endothelial cells may lack complete functional maturation in vitro. J Vasc Res. 2006;43:411.

47. Weiss P. Cellular dynamics Rev. Mod. Phys. 1959;31:11.

48. Burridge K, Chrzanowska-Wodnicka M. Focal adhesions, contractility, and signaling. Annu Rev Cell Dev Biol. 1996;12:463.

49. Schwartz MA, Ginsberg MH. Networks and crosstalk: integrin signalling spreads. Nat Cell Biol. 2002;4:E65.

50. Moghe PV, Ezzell RM, Toner M, Tompkins RG, Yarmush ML. Role of $\beta 1$ Integrin Distribution in Morphology and Function of CollagenSandwiched Hepatocytes. Tissue Eng. 1997;1:1.

51. Cukierman E, Pankov R, Stevens DR, Yamada KM. Taking cellmatrix adhesions to the third dimension. Science. 2001;294:1708.

52. Wolf K, Mazo I, Leung H, Engelke K, von Andrian UH, Deryugina EI, Strongin AY, Bröcker EB, Friedl P. Compensation mechanism in tumor cell migration: mesenchymal-amoeboid transition after blocking of pericellular proteolysis. J Cell Biol. 2003;160:267.

53. Schor SL, Ellis IR, Harada K, Motegi K, Anderson AR, Chaplain MA, Keatch RP, Schor AM. A novel 'sandwich' assay for quantifying chemo-regulated cell migration within 3-dimensional matrices: wound healing cytokines exhibit distinct motogenic activities compared to the transmembrane assay. Cell Motil Cytoskeleton. 2006;63:287. 
54. Lee EJ, Hwang CM, Baek DH, Lee SH. Fabrication of microfluidic system for the assessment of cell migration on 3D micropatterned substrates. Conf Proc IEEE Eng Med Biol Soc. 2009;2009:6034.

55. Zaman MH, Trapani LM, Sieminski AL, Mackellar D, Gong H, Kamm RD, Wells A, Lauffenburger DA, Matsudaira P. Migration of tumor cells in 3D matrices is governed by matrix stiffness along with cellmatrix adhesion and proteolysis. Proc Natl Acad Sci U S A. 2006;103:10889.

56. Benya PD, Shaffer JD. Dedifferentiated chondrocytes reexpress the differentiated collagen phenotype when cultured in agarose gels. Cell. 1982;30:215.

57. Dunn JC, Tompkins RG, Yarmush ML. Long-term in vitro function of adult hepatocytes in a collagen sandwich configuration. Biotechnol Prog. 1991; 7:237.

58. Emerman JT, Pitelka DR. Maintenance and induction of morphological differentiation in dissociated mammary epithelium on floating collagen membranes. In Vitro. 1977;13:316.

59. Petersen OW, Rønnov-Jessen L, Howlett AR, Bissell MJ. Interaction with basement membrane serves to rapidly distinguish growth and differentiation pattern of normal and malignant human breast epithelial cells. Proc Natl Acad Sci U S A. 1992;89:9064.

60. Parry G, Lee EY, Farson D, Koval M, Bissell MJ. Collagenous substrata regulate the nature and distribution of glycosaminoglycans produced by differentiated cultures of mouse mammary epithelial cells. Exp Cell Res. 1985;156:487.

61. Keely PJ, Fong AM, Zutter MM, Santoro SA. Alteration of collagendependent adhesion, motility, and morphogenesis by the expression of antisense alpha 2 integrin mRNA in mammary cells. J Cell Sci. 1995;108:595.

62. Weaver VM, Petersen OW, Wang F, Larabell CA, Briand P, Damsky C, Bissell MJ. Reversion of the malignant phenotype of human breast cells in three-dimensional culture and in vivo by integrin blocking antibodies. J Cell Biol. 1997;137:231.

63. Petrie RJ, Gavara N, Chadwick RS, Yamada KM. Nonpolarized signaling reveals two distinct modes of 3D cell migration. J Cell Biol. 2012;197:439. 
64. Raghavan S, Shen CJ, Desai RA, Sniadecki NJ, Nelson CM, Chen CS. Decoupling diffusional from dimensional control of signaling in 3D culture reveals a role for myosin in tubulogenesis. J Cell Sci. 2010;123:2877.

65. Lee SH, Miller JS, Moon JJ, West JL. Proteolytically degradable hydrogels with a fluorogenic substrate for studies of cellular proteolytic activity and migration. Biotechnol Prog. 2005;21:1736.

66. Raeber GP, Lutolf MP, Hubbell JA. Molecularly engineered PEG hydrogels: a novel model system for proteolytically mediated cell migration. Biophys J. 2005;89:1374.

67. Upton ML, Gilchrist CL, Guilak F, Setton LA. Transfer of macroscale tissue strain to microscale cell regions in the deformed meniscus. Biophys J. 2008;95:2116.

68. Dunn JC, Yarmush ML, Koebe HG, Tompkins RG. Hepatocyte function and extracellular matrix geometry: long-term culture in a sandwich configuration. FASEB J. 1989;3:174.

69. Ezzell RM, Toner M, Hendricks K, Dunn JC, Tompkins RG, Yarmush ML. Effect of collagen gel configuration on the cytoskeleton in cultured rat hepatocytes. Exp Cell Res. 1993;208:442.

70. Heidebrecht F, Schulz I, Keller M, Behrens SE, Bader A. Improved protocols for protein and RNA isolation from three-dimensional collagen sandwich cultures of primary hepatocytes. Anal Biochem. 2009;393:141.

71. Tuschl G, Hrach J, Walter Y, Hewitt PG, Mueller SO. Serum-free collagen sandwich cultures of adult rat hepatocytes maintain liverlike properties long term: a valuable model for in vitro toxicity and drug-drug interaction studies. Chem Biol Interact. 2009;181:124.

72. Kim Y, Lasher CD, Milford LM, Murali TM, Rajagopalan P. A comparative study of genome-wide transcriptional profiles of primary hepatocytes in collagen sandwich and monolayer cultures. Tissue Eng Part C Methods. 2010;16:1449.

73. Beningo KA, Dembo M, Wang YL. Responses of fibroblasts to anchorage of dorsal extracellular matrix receptors. Proc Natl Acad Sci U S A. 2004;101:18024. 
74. Fraley SI, Feng Y, Krishnamurthy R, Kim DH, Celedon A, Longmore GD, Wirtz D. A distinctive role for focal adhesion proteins in threedimensional cell motility. Nat Cell Biol. 2010;12:598.

75. Fischer RS, Gardel M, Ma X, Adelstein RS, Waterman CM. Local cortical tension by myosin II guides 3D endothelial cell branching. Curr Biol. 2009;19:260.

76. Zhang J, Klos M, Wilson GF, Herman AM, Lian X, Raval KK, Barron MR, Hou L, Soerens AG, Yu J, Palecek SP, Lyons GE, Thomson JA, Herron TJ, Jalife J, Kamp TJ. Extracellular matrix promotes highly efficient cardiac differentiation of human pluripotent stem cells: the matrix sandwich method. Circ Res. 2012;111:1125. 

Chapter 2. Objectives 

As mentioned before, several studies have shown different cell behaviour on traditional 2D substrates compared to in vivo and 3D systems, suggesting that closer environments to the in vivo should be used in order to get reliable results from cell culture models that might be then extrapolated to the in vivo situation. However, the use of a wide variety of complex 3D systems has led to contradictory information and has made difficult to disentangle the actual origin of cell behaviour in these models. Moreover, literature frequently presents studies on 2D cell cultures, 3D cell cultures or even in vivo, but rarely the same work compares results obtained using different culture platforms.

One of the main differences between 2D and the in vivo environment is the distribution of cell receptors anchored to the extracellular matrix, which may trigger multiple signalling pathways and modulate important processes such as cell growth and gene expression. Hence we hypothesised that the excitation of dorsal receptors via a sandwich-like culture could trigger a cell behaviour closer to the 3D environment than the traditional 2D substrates. So the main objectives of this thesis were:

1) To develop a reliable and simple sandwich culture system with convenient properties for cell culture (allowing microscopic imaging, cellular extractions...).

2) To validate the use of this sandwich culture system as a tool to study cell behaviour in a closer 3D environment.

3) To study the effect of the sandwich culture (comparing to the control ventral 2D substrate) in cell fate including morphology, adhesion, differentiation or cell migration.

4) To evaluate the role of different parameters of the sandwich culture in cell behaviour (i.e. ventral $\mathrm{v}$ dorsal stimuli or biological and mechanical stimuli). 

Chapter 3. Materials and methods 

The main experimental methods employed in this work, which has been commonly used in different sections of this thesis, are described in this chapter. More specific experimental methods or conditions are detailed in the corresponding chapter for the sake of clarity.

\subsection{Materials}

Different materials (and coated with different proteins) have been used during this work according to their specific properties and to get reliable conditions for comparisons. For the sake of clarity, figure 3.1 depicts the different conditions that have been used during this work either as ventral or dorsal stimuli.
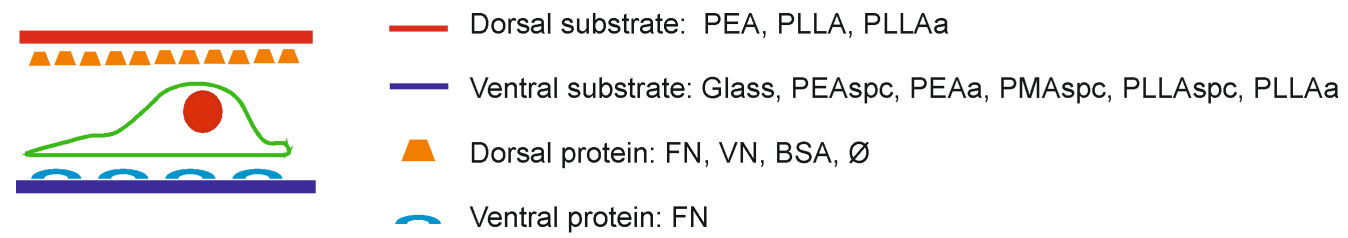

Figure 3.1. Sketch of the sandwich-like model showing the materials and proteins that have been used as ventral or dorsal stimuli.

\section{Glass coverslips}

Glass coverslips (Menzel-Glass) were cleaned in an ultrasonic bath for 30 min immersed in absolute ethanol in order to remove dirt and organic impurities. Then coverslips were washed three times in ethanol and dried in an oven before its use as a substrate for cell culture (glass in figure 3.1) or as a support for spin coating.

\section{Polymerization of acrylic polymers}

Different acrylic polymers and in different sort of fabrication were used during this work. Concretely, films, spin coated and electrospun materials of poly(ethyl acrylate) and poly(methyl acrylate) were used as figure 3.1 shows. Their fabrication process is detailed below.

Polymer sheets were obtained by bulk radical polymerization of a solution of the corresponding alkyl acrylate, i.e., ethyl acrylate (EA) and methyl acrylate (MA) (99\% pure, Sigma-Aldrich, Steinheim, Germany) in anaerobic conditions by using 0,35 and $1 \mathrm{wt} \%$ benzoin respectively (98\% 
pure, Scharlau, Barcelona, Spain) as photoinitiator of the reaction. As a result, polymer films of poly(ethyl acrylate) and poly(methyl acrylate) were obtained (called PEA and PMA respectively). The polymerization was carried out up to limiting conversion by UV exposure o/n. After polymerization, low molecular-mass substances were extracted from the material by drying in vacuum at $60 \stackrel{\circ}{C}$ to constant weight for several days.

\section{Poly (lactic acid)}

Poly (lactic acid) (PLA) is a bio-degradable thermoplastic polymer that can be produced from lactic acid. Due to its chiral nature, several forms exist. In this work it was used poly-L-lactide (PLLA) obtained from NatureWorks (>99 \% pure, $144 \mathrm{~g} / \mathrm{mol}$, Netherlands).

\subsection{Materials fabrication \\ Polymerization}

When thin PEA films to be used as top substrates (figure 3.1) were fabricated, polymerization was carried out in chambers of $0.4 \mathrm{~mm}$ thickness. Rounded samples were cut from the polymerized film (PEA film) and, the day before the culture, these samples were washed in an ultrasonic bath for 5 min and hydrated overnight in Dulbecco's phosphate buffered saline (DPBS, Invitrogen).

\section{Spin casting}

Thin films of PEA, PMA and PLLA (PEAspc, PMAspc and PLLAspc respectively) were prepared by making use of a spin-coater (Brewer Science, Rolla, USA). Spin coating is a widely used technique to get uniform thin polymer films on flat substrates based on the fact that the polymer solution spreads over the substrate by centrifugal force when this is rotated at high speed (figure 3.2A). Since the rotation is continued the solution spins off the substrate. Moreover the final film thickness depends on the solution (viscosity, evaporation rate, surface tension, etc.), the substrate surface (wettability, roughness) and the parameters of the spinning process (rotational speed, acceleration, time). 
Specific conditions for the spin casting of each polymer are summarised in table 3.1. Spin coating was performed on clean glass coverslips of $12 \mathrm{~mm}$ diameter and then samples were dried under vacuum

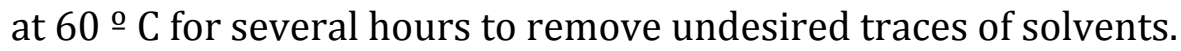

Table 3.1. Spin casting conditions for each polymer.

\begin{tabular}{lllll}
\hline Polymer & $\begin{array}{l}\text { Solution } \\
(\% \boldsymbol{w t})\end{array}$ & $\begin{array}{l}\text { Velocity } \\
(\mathbf{r p m})\end{array}$ & $\begin{array}{l}\text { Acceleration } \\
(\mathbf{r p m})\end{array}$ & $\begin{array}{l}\text { Time } \\
\text { (sec) }\end{array}$ \\
\hline PEA & $2,5 \%$ in toluene & 2000 & 3000 & 30 \\
PMA & 6\% in toluene & 2000 & 3000 & 30 \\
PLLA & 2\% in chloroform & 2000 & 2000 & 5 \\
\hline
\end{tabular}

\section{Electrospinning}

Electrospinning is a common technique used in tissue engineering to produce nanofibers from a polymeric solution in order to mimic the fibrillar nature of the extracellular matrix (ECM). It is based on the principle that at a certain voltage, a charged polymer jet is ejected from a polymer droplet moving in the direction of an external electric field. This jet is then randomly deposited on a substrate as a nonwoven mat of nanofibres with diameters that can range from few nanometers to several microns (figure 3.2B). ${ }^{1}$ Different parameters highly influence fiber dimension and morphology such as the own properties of the polymer (molecular weight and distribution, glass-transition temperature, solubility etc.), the properties of the polymer solution (such as viscosity, surface tension, viscoelasticity, concentration, diffusion coefficient, vapour pressure, dielectric and electrical properties) and other external parameters (such as feed rate, diameter of the needle, collector distance, temperature and humidity).

Polymers were dissolved in hexafluoroisopropanol (HFIP; >99\% pure, Sigma) and electrospun using a needle of $0.15 \mathrm{~mm}$ of internal diameter (EFD International) and a $1 \mathrm{~mL}$ syringe with an internal diameter of $5 \mathrm{~mm}$. Polymer solutions were electrospun at a constant feed rate of $900 \mu \mathrm{l} / \mathrm{h}$ with a programmable syringe pump (New Era Pump Systems, Wantagh, NY, USA) with a specific voltage (Glassman High 
Voltage, High Bride, NJ, USA) and collector distance (table 3.2). Randomly electrospun fibers were collected on glass coverslips placed on aluminium foil, while aligned fibers were collected by electrospinning the solution onto a rotating drum where glass coverslips or polytetrafluoroethylene (PTFE) washers were stuck.

Table 3.2. Electrospinning conditions for each polymer.

\begin{tabular}{llllll}
\hline Polymer & $\begin{array}{l}\text { Solution } \\
(\% \boldsymbol{w})\end{array}$ & $\begin{array}{l}\text { Distance } \\
\text { collector }(\boldsymbol{c m})\end{array}$ & $\begin{array}{l}\text { Voltage } \\
(\boldsymbol{k} \boldsymbol{V})\end{array}$ & $\begin{array}{l}\text { Linear } \\
(\mathbf{c m} / \boldsymbol{s})\end{array}$ & velocity \\
\hline PEA & $2 \%$ in HFIP & 20 & 12,5 & 337,5 & \\
PLLA & $8 \%$ in HFIP & 12 & 30 & 1125 & \\
\hline
\end{tabular}

\section{Solvent casting}

A solution of $2 \%$ PLLA in chloroform (Scharlau) was cast in stainless steel washers and allowed to evaporate (figure 3.2C). Resulting films were thermally treated at $200^{\circ} \mathrm{C}$ for 5 minutes and immersed in MilliQ water for 10 min before peeling them off. Solvent casted PLLA thickness was analyzed using scanning electron microscopy (JEOL JSM 6300) and Minitest coating thickness gauges (Minitest 2100 ElektroPhysics).
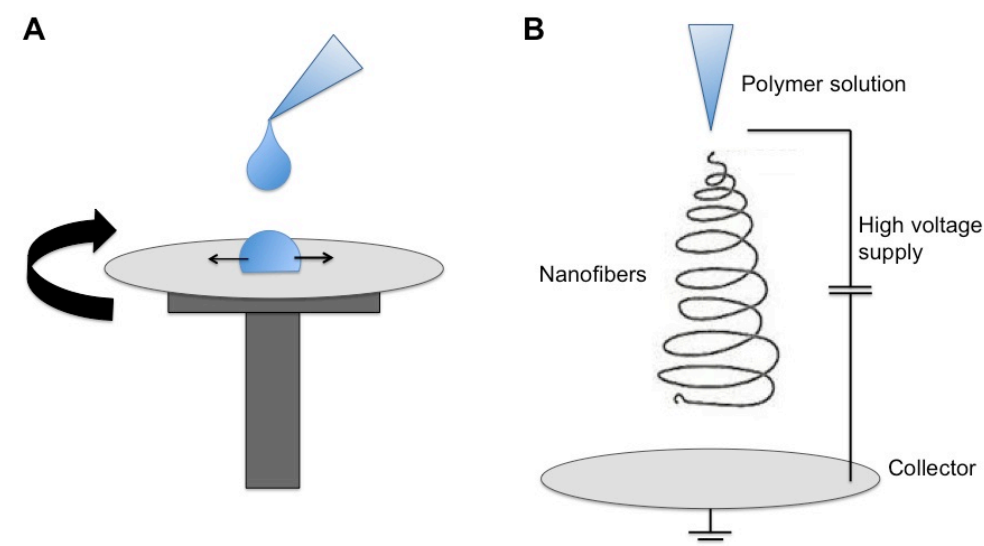

C

Figure 3.2. Material fabrication processes used during this work. (A) Spin casting, (B) electrospinning and (C) solvent casting. 


\subsection{Materials characterisation}

\section{Scanning electron microscopy}

Samples were characterised by scanning electron microscopy (SEM) using a JEOL JSM 6300 system (JEOL Ltd., Tokyo, Japan) operating at $10 \mathrm{kV}$. Samples were sputtered with gold and visualised. SEM images were used to obtain qualitative data about electrospun fibres anisotropy using ImageJ software. ${ }^{2}$ Shortly thereafter, Fourier-Fast transform of the squared picture was realized, and after a counter-clockwise rotation of $90^{\circ}$ (in order to recover original fiber direction modified by the Fourier Transform) a radial projection of pixel intensity was determined using an external plug-in developed by 0 'Connell. ${ }^{3}$ Normalized values (with respect to maximum intensity) are presented.

\section{Atomic Force Microscopy}

Atomic Force Microscopy (AFM) was performed in a JPK Nanowizard 3 BioScience AFM (JPK, Germany). Fibronectin distribution was analised operating in contact mode (AC) that consists in a flexible cantilever oscillating up and down near its resonance frequency with given amplitude. A laser beam impacts the cantilever and thus it is reflected and deflected in a regular pattern over a photodiode array, generating a sinusoidal electronic signal. A piezoelectric scanner keeps the tip in constant contact with the material following the surface roughness by moving the tip up and down in the z-axis. So, when the tip comes into contact with a change in the surface, there is a shift in the oscillation amplitude that provides information about the topography of the sample (figure 3.3). The SPM and DP 4.2 software version were used for image processing and analysis. Si-cantilevers from Nanoworld AG (Switzerland) were used with force constant of $2.8 \mathrm{~N} / \mathrm{m}$ and resonance frequency of 75 $\mathrm{kHz}$. The phase signal was set to zero at a frequency 5-10\% lower than the resonance one. Drive amplitude was $700 \mathrm{mV}$ and the amplitude setpoint was $650 \mathrm{mV}$. 


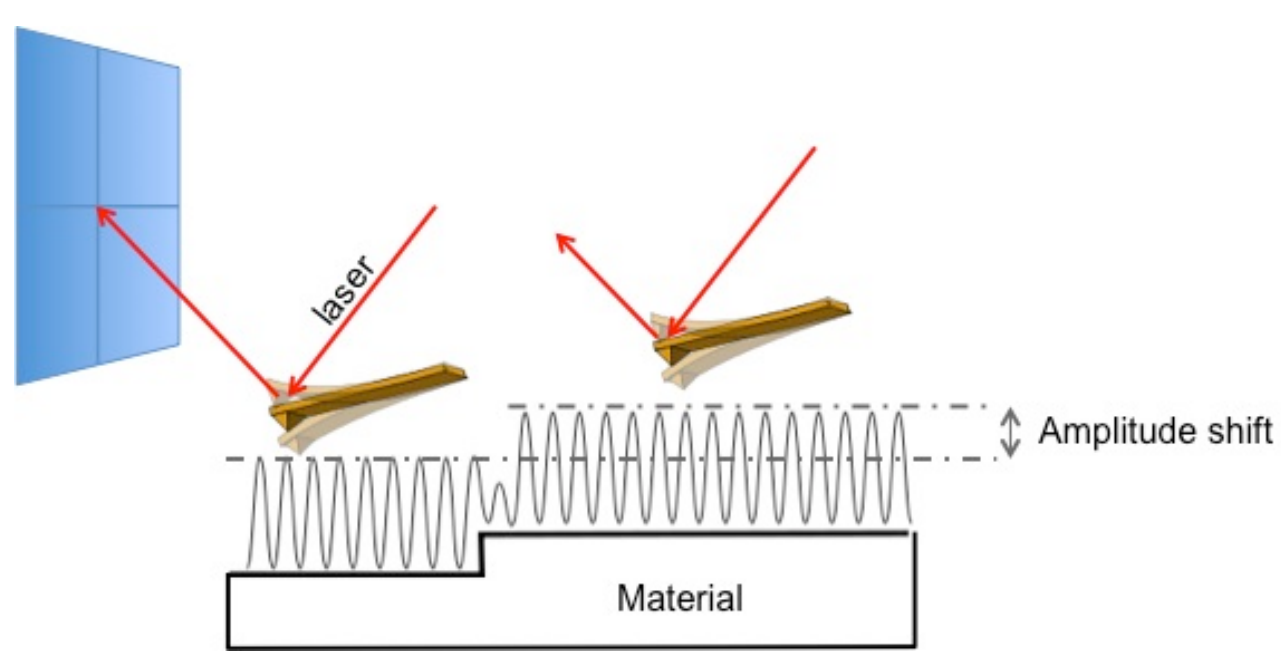

Figure 3.3. Representation of the contact mode in the AFM. Adapted from reference 4 .

Force spectroscopy measurements were performed in order to determine the strength of the FN-material interaction. Si-nitride PEGylated cantilevers ( $\mathrm{COOH}$ terminated) from Novascan with force constant of $0.06 \mathrm{~N} / \mathrm{m}$ were functionalized with $\mathrm{FN}$ according to the manufacturer's instructions. Briefly, (1-ethyl-3-[3dimethylaminopropyl]carbodiimide hydrochloride (EDC) was used as a carboxyl and amine-reactive zero-length crosslinker and 1mM Glycine in DPBS as blocking buffer. The FN-material interaction was then tested for every material in 64 different points at a relative setpoint of $0.4 \mathrm{~V}(\approx 500$ $600 \mathrm{pN}$ ), constant speed of $0.5 \mu \mathrm{m} / \mathrm{sec}$, z-length of $5 \mu \mathrm{m}$ and extension delay of $1 \mathrm{sec}$. Figure 3.4A shows a representative curve that consists in the approach of the tip to the surface (to allow the protein adsorption) and then its retraction (to remove the protein from the material surface). The strength of the protein-material interaction is therefore shown in the retraction curve and can be analysed in terms of work (area of the peak) and adhesion force (depth of the peak) (figure 3.4C). Besides, from the same curve, it can be obtained the rupture length (width of the curve), which shows the distance where the functionalised tip totally detaches from the material surface. Hence, this parameter shows protein unfolding/stretching processes. 


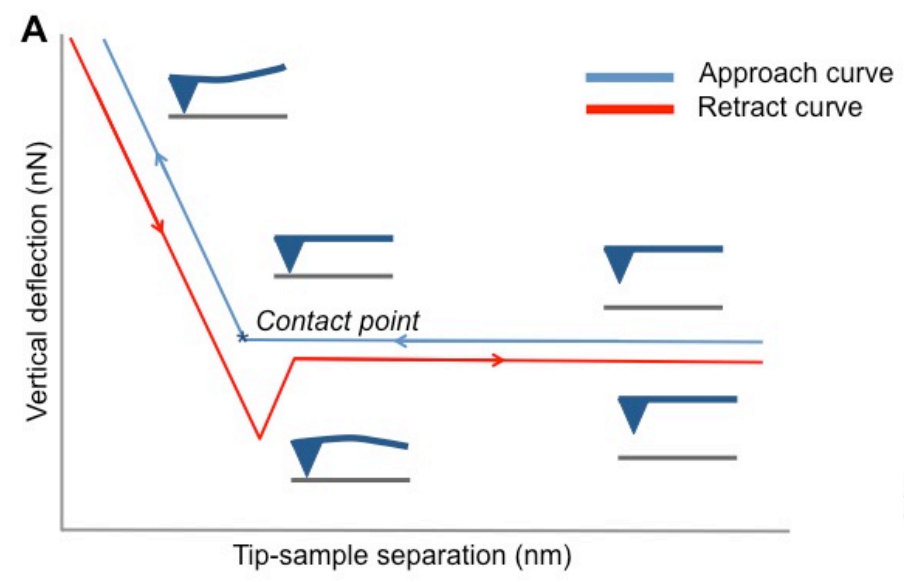

B
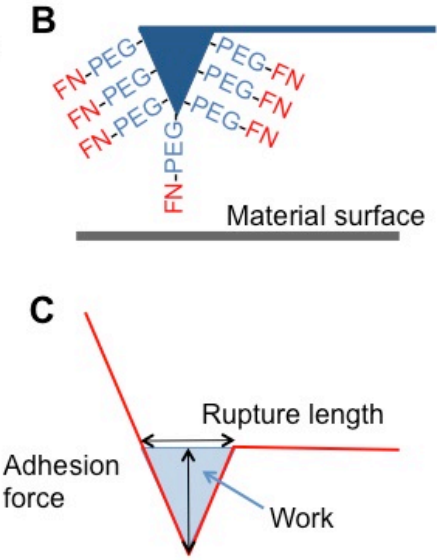

Figure 3.4. Force spectroscopy measurements. (A) Representative curve depicting the different states of the tip-material interaction. (B) Sketch of the Sinitride tip functionalised with fibronectin (FN). (C) Representative retraction curve depicting the 3 protein-material parameters that can be analysed.

\subsection{Cell culture}

\section{Protein Adsorption}

During this work, the biological input of different protein coatings and their effect on cell fate were studied (figure 3.1). To do so, substrates were incubated with protein solutions for $1 \mathrm{~h}$ at room temperature. Afterwards samples were rinsed with Dulbecco's Phosphate Saline Buffer (DPBS) to eliminate the non-adsorbed protein excess. Table 3.3 summarises the different protein coatings used during this work.

Table 3.3. Protein coatings used during this work.

\begin{tabular}{lllll}
\hline \multicolumn{2}{l}{ Protein coating } & & Company & Solution \\
\hline $\begin{array}{l}\text { Fibronectin from human } \\
\text { (FN) }\end{array}$ & plasma & Sigma & $20 \mu \mathrm{g} / \mathrm{mL}$ in DPBS \\
$\begin{array}{l}\text { Heat-denatured Bovine } \\
\text { Albumin Fraction V (BSA) }\end{array}$ & & & \\
$\begin{array}{l}\text { Vitronectin from human } \\
\text { (VN) }\end{array}$ & & & & \\
\hline
\end{tabular}




\section{Cell Culture}

Prior to seeding, samples were sterilized by UV exposure for 30 min (30 min each side in the case of the dorsal substrates) and coated with a protein as described before. Then cells were seeded on the different samples in serum-free conditions seeking to direct specific cell adhesion to the pre-adsorbed protein and to study therefore the specific role of this coating in cell fate. However, cell viability and growth in long-term cultures depends on the need of growth factors and other biomolecules to keep growing. Hence medium was changed in long lasting experiments $(>7 \mathrm{~h})$ to serum-containing medium after 3 hours of culture.

To assemble the sandwich culture, the dorsal substrate was gently laid over the bottom substrate either immediately $\left(\mathrm{SW}^{t 0}\right)$ or after $3 \mathrm{~h}$ of culture (SW) (see figure 3.5). When laying the substrate just after cell seeding, a highly concentrated cellular suspension was used in order to avoid cell loss after laying the upper substrate. If laid after $3 \mathrm{~h}$ of culture, excess of medium on the bottom surface was previously removed. Sandwich-like cultures were then maintained at $37^{\circ} \mathrm{C}$ in a humidified atmosphere under $5 \% \mathrm{CO}_{2}$.

3 hours

$\stackrel{\text { Cell seeding Dorsal stimulation End of culture }}{\longrightarrow}$
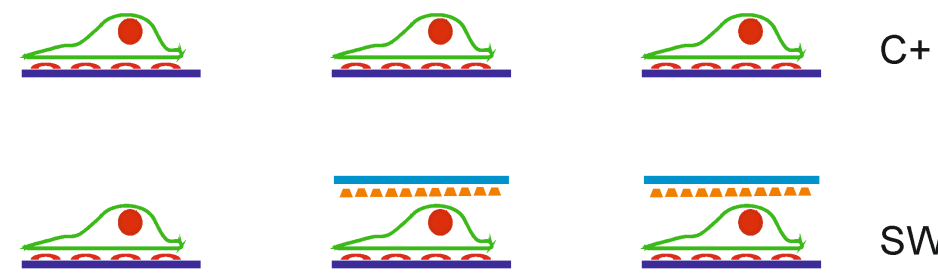

SW
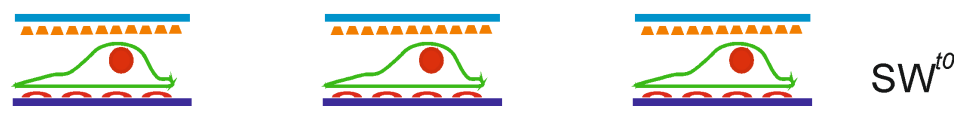

Figure 3.5. Timing diagram showing the cell culture procedure and the nomenclature used for every condition.

As several conditions have been studied, a specific nomenclature was used overall the study unless otherwise noticed: $S W_{x}{ }^{y}$ with x-ventral and y-dorsal material conditions. 


\subsection{Biological characterisation \\ Image processing}

All image processing and analysis was done using Adobe Photoshop CS5 and Image J. Briefly, brightness and contrast were modified in bright field images in order to define the cell shape with Adobe Photoshop CS5. Thereafter cell morphology was quantified using ImageJ software by calculating parameters such as cell area, aspect ratio (major axis/minor axis), circularity ( $4 \pi \mathrm{x}$ area/perimeter ${ }^{2}$ ) and roundness (4 $\mathrm{x}$ area $/ \pi \mathrm{x}$ [major axis] $^{2}$ ). Circularity and roundness correspond to a value of 1 for a perfect circle. At least 20 cells were analysed for each condition.

\section{Live/Dead}

Viability of cells was measured by live/dead assay (Invitrogen) following manufacturer's instructions. Briefly, cells in culture were simultaneously incubated with $2 \mu \mathrm{m}$ calcein $\mathrm{AM}$ and $4 \mu \mathrm{M}$ Ethidium homodimer-1. Live cells convert the cell-permeant calcein AM to the fluorescent green calcein due to the intracellular esterase activity; while the ethidium homodimer is able to enter only into cells with damaged membranes and binds to the nucleic acids producing a bright red fluorescent in dead cells. Viable green fluorescent cells and dead red fluorescent cells were counted in different fields of the sample and viability was given as the percentage of living cells.

\section{Immunofluorescence}

Here it is described the most common protocol used for the immunodetection of different proteins (see table 3.4). However this protocol was slightly change for the detection of some proteins and will be better explained in their specific chapter.

Once the culture was finished, cells were fixed with $10 \%$ formalin (Sigma) for $30 \mathrm{~min}$ at $4^{\circ} \mathrm{C}$. After fixation, cells were permeabilised for 5 min at room temperature using $0.5 \%$ Triton X-100 (Sigma) in HEPES buffer $20 \mathrm{mM}$ (Sigma) supplemented with $0.3 \mathrm{M}$ saccharose, $50 \mathrm{mM} \mathrm{NaCl}$ (Sigma) and $3 \mathrm{mM} \mathrm{MgCl}_{2}$ hexahydrate (Scharlab), and then incubated in blocking buffer (1 \% BSA in DPBS) for $30 \mathrm{~min}$. Samples were then incubated with the primary antibody for $1 \mathrm{~h}$ and, after several washes in 
$0.5 \%$ Tween 20/DPBS, in the secondary antibody for another hour. Finally, samples were washed before being mounted in Vectashield containing 4',6-diamidino-2-phenylindole (DAPI; Vector Laboratories, UK). A Nikon microscope (Nikon Eclipse 80 i) was used for cellular imaging.

Table 3.4. Antibodies and fluorophores employed in this work.

\begin{tabular}{|c|c|c|c|}
\hline Reagent & Company & Reference & Dilution \\
\hline Anti-Vinculin & Sigma & V9131 & $1: 400$ \\
\hline Anti-MMP2 & Abcam & Ab39898 & $1: 500$ \\
\hline Anti-MMP13 & Abcam & Ab58836 & $1: 200$ \\
\hline Anti-Tubulin & Abcam & Ab7291 & $1: 1000$ \\
\hline Anti-Paxillin & Sigma & P1093 & $1: 200$ \\
\hline Anti- $\beta_{1}$ integrin & BD Bioscience & 550531 & $1: 50$ \\
\hline Anti- $\alpha_{5}$ integrin & Millipore & AB1921 & $1: 1000$ \\
\hline BODIPY FL phallacidin & Molecular Probes & $\mathrm{B} 607$ & $1: 100$ \\
\hline $\begin{array}{l}\text { Alexa Fluor } 488 \\
\text { antibody }\end{array}$ & Life Technologies & A11029 & $1: 200$ \\
\hline $\begin{array}{l}\text { Cy3-conjugated } \\
\text { antibody }\end{array}$ & $\begin{array}{l}\text { Jackson } \\
\text { Immunoresearch }\end{array}$ & $\begin{array}{l}\text { Ab6953 } \\
\text { AB6949 }\end{array}$ & $1: 100$ \\
\hline
\end{tabular}

\section{Western Blotting}

The content of different cellular proteins was analysed by western blot. First, cells were lysed with RIPA buffer (Tris-HCl 50 mM, $1 \%$ Nonidet P40, $0.25 \%$ Na deoxycholate, $\mathrm{NaCl} 150 \mathrm{mM}$, EDTA $1 \mathrm{mM}$ ) supplemented with protease inhibitor cocktail tablets (Complete, Roche) to collect proteins avoiding its degradation. The lysates were concentrated with Microcon YM-30 Centrifugal Filters units (Millipore) and then subjected to $7 \%$ SDS-PAGE gel electrophoresis and transferred to a positively charged polyvinylidene difluoride nylon membrane (PVDF, GE Healthcare) using a semidry transfer cell system (Biorad). Blots were blocked by immersion in $5 \%$ skimmed milk in PBS for 30 minutes at room temperature and then incubated with primary antibodies in PBS containing $0.1 \%$ Tween 20 and $2 \%$ skimmed milk (see table 3.5 ). After several washes with PBS/0.1\% 
Tween 20, the blot was incubated in horseradish peroxidase-conjugated antibody (HRP antibody, GE Healthcare) in PBS containing $0.1 \%$ Tween 20 and $2 \%$ milk for 1 hour at room temperature. After several washes with PBS containing $0.1 \%$ Tween 20 and $2 \%$ milk, immunoreactive bands were visualized using Supersignal West Femto Maximum Sensitivity Substrate (Thermo Scientific, Alcobendas, Spain), analised by ImageJ and normalised to the housekeeping protein $\alpha$-tubulin.

Table 3.5. List of the antibodies employed during western blot procedure.

\begin{tabular}{lllll}
\hline Antibody & Company & Reference & Dilution & $\begin{array}{l}\text { HRP } \\
\text { antibody }\end{array}$ \\
\hline Anti-FAK & Upstate & $06-543$ & $1: 2500$ & $1: 10000$ \\
$\begin{array}{l}\text { Anti- } \\
\text { pFAK }\end{array}$ & Millipore & MAB1144 & $1: 2500$ & $1: 10000$ \\
$\begin{array}{l}\text { Anti- } \boldsymbol{\alpha}_{\mathbf{v}} \\
\text { integrin }\end{array}$ & Millipore & MAB1930 & $1: 1000$ & $1: 10000$ \\
$\begin{array}{l}\text { Anti- } \boldsymbol{\alpha}_{\mathbf{5}} \\
\text { integrin }\end{array}$ & $\begin{array}{l}\text { Santa Cruz } \\
\text { Biotechnology }\end{array}$ & sc-10729 & $1: 100$ & $1: 10000$ \\
\hline
\end{tabular}

\section{Proliferation assay}

Cell proliferation was evaluated based on the measurement of 5bromodeoxyuridine (BrdU, Sigma-Aldrich) uptake during DNA synthesis in proliferating cells. $10 \mu \mathrm{g} / \mathrm{mL}$ of BrdU was added to the medium after $2 \mathrm{~h}$ of cell seeding. After 6 or $24 \mathrm{~h}$ of culture, cells were fixed with $10 \%$ formalin solution (Sigma-Aldrich) for $30 \mathrm{~min}$ at $4{ }^{\circ} \mathrm{C}$ and then washed three times in PBS. DNA was then denatured by incubating in $1 \mathrm{~N} \mathrm{HCl}$ at 65 ${ }^{\circ} \mathrm{C}$ for 15 min with agitation. After washing three times in neutralizing buffer (50 mM NaCl, $100 \mathrm{mM}$ Tris-HCl, pH 7.4) for 20 min each and twice in PBS, cells were blocked with $1 \%$ BSA and $5 \%$ FBS in DPBS at room temperature for $10 \mathrm{~min}$. After that, cells were incubated at $37{ }^{\circ} \mathrm{C}$ for $1 \mathrm{~h}$ with mouse monoclonal antibody against BrdU (Sigma) diluted 1:1000 and then washed twice with PBS. Cells were then incubated with Cy3 conjugated secondary antibody (Jackson Immunoresearch) diluted 1:200 and DAPI (Dil 1/2500, Sigma-Aldrich) at room temperature for $1 \mathrm{~h}$. After further washings in PBS, cells were mounted and observed under fluorescent microscopy (Nikon Eclipse 80i). 


\section{Fibronectin reorganisation}

The ability of cells to reorganise the previously adsorbed FN was monitored by immunofluorescence. To assess only the reorganisation of the coated FN and avoid the cell secreted FN, the HFN7.1 antibody specific for human FN was used.

Once the culture was finished, cells were fixed with $10 \%$ formalin. Then samples were washed with DPBS and cells were permeabilised for 5 min at room temperature. Afterwards, samples were blocked in DPBS $/ 1 \%$ BSA and incubated with HFN 7.1 antibody (Developmental Studies Hybridoma Bank), which only recognises human FN. After 1 hour of incubation, samples were rinsed in $0.5 \%$ Tween 20/DPBS, and then incubated in Cy3-conjugated secondary antibody (Jackson Immunoresearch, 1:400), BODIPY FL phallacidin and DAPI. Heat maps were performed using an external plug-in of ImageJ (HeatMap Histogram).

\section{Time-lapse cell imaging}

Images were acquired every 20 min for $24 \mathrm{~h}$ using a Leica DMI 6000 inverted microscope (Leica Microsystems Heidelberg GmbH, Mannheim, Germany) with a 10X dry objective. During the observation, the samples were maintained at $37{ }^{\circ} \mathrm{C}$ and supplied with a $95 \%$ air and $5 \% \mathrm{CO}_{2}$ humidified gas mixture. Phase contrast images were gathered at $20 \mathrm{~min}$ intervals along $24 \mathrm{~h}$ of culture. For gap closure measurements, images were processed using the external plug-in MiToBo in ImageJ software in order to obtain quantitative data about the dynamics in cell migration. ${ }^{5}$

\section{Myogenic differentiation}

For determining the myodiferentiation, C2C12 cells were cultured for 4 days under differentiation conditions and immunostained for sarcomeric myosin. Briefly, C2C12 cells were seeded at 17,500 cells $\mathrm{cm}^{2}$ in DMEM without serum supplemented with $1 \%$ penicillin-streptomycin and $1 \%$ insulin-transferrin-selenium-X (Invitrogen) in order to induce myogenic differentiation. Cultures were fixed after 4 days in $70 \%$ ethanol/37 \% formaldehyde/glacial acetic acid (20:2:1) and then blocked in $5 \%$ goat serum in DPBS for $1 \mathrm{~h}$. Samples were sequentially incubated in MF-20 mouse antibody (Developmental Studies Hybridoma Bank, University of 
Iowa, USA) and anti-mouse Cy3-conjugated secondary antibody (Jackson Immunoresearch) with 4,6-diamidino-2-phenylindole (DAPI, Sigma) for 1 hour. Cultures were scored by the percentage of positive cells for sarcomeric myosin using the CellC image analysis software. ${ }^{6}$ In order to obtain quantitative data about cell anisotropy, the images of sarcomeric myosin staining were processed using Image software following an already described procedure. ${ }^{3}$

\section{Alkaline phosphatase (ALP)/Neutral Red staining}

ALP staining was performed following manufacturer's suggestions (Sigma-aldrich). Briefly, cells were fixed in citrate-acetone-formaldehyde solution and then incubated for 15 min protected from direct light in Sodium Nitrite/Naphtol alkaline solution. Then samples were wash in deionized water and counterstained with Neutral Red for 2 minutes. So, cells undergoing osteogenic differentiation showed a blue stain while the rest showed a red stain. Finally, cultures were scored quantifying the area ( $\%$ of the total image) covered by the positive staining (blue) by using ImageJ.

\section{Gene expression analysis by quantitative real time PCR.}

Gene expression of different markers (see table 3.6) was analysed after 14 days of culture. First, hMSCs were lysed and RNA was extracted using a Qiagen RNeasy micro kit (DNase treatment included). RNA quantity and integrity was measured with a NanoDrop 1000 (ThermoScientific). Then 200 ng of RNA (when possible since cell proliferation is hindered within sandwich culture and therefore less amount of RNA can be obtained from these samples) were reverse transcribed using the QuantiTect Rev Transcription Kit (Qiagen). Real-time qPCR was carried out using the 7500 Real Time PCR system from Applied Biosystems. Gene expression was normalized to GAPDH expression, used as the house-keeping gene, and then to the $2 \mathrm{D}$ value so that the final results show the fold increase over the $2 \mathrm{D}$ condition. 
Table 3.6. Primer sequences used for the quantitative real time PCR.

\begin{tabular}{|c|c|c|}
\hline Gene & Pair & Sequence \\
\hline \multirow{2}{*}{$\begin{array}{c}\text { ALCAM } \\
\text { (self-renewal) }\end{array}$} & Forward & 5'-ACG ATG AGG CAG CAG AGA TAA GT-3' \\
\hline & Reverse & 5'-CAG CAA GGA GGA GAC CAA CAA C-3' \\
\hline \multirow{2}{*}{$\begin{array}{c}\text { CD63 } \\
\text { (self-renewal) }\end{array}$} & Forward & 5'-GCT GTG GGG CTG CTA ACT AC-3' \\
\hline & Reverse & 5'-ATC CCA CAG CCC ACA GTA AC-3' \\
\hline \multirow{2}{*}{$\begin{array}{c}\text { PPAR- } \gamma \\
\text { (adipogenic) }\end{array}$} & Forward & 5'-TGT GAA GCC CAT TGA AGA CA-3' \\
\hline & Reverse & 5'-CTG CAG TAG CTG CAC GTG TT-3' \\
\hline \multirow{2}{*}{$\begin{array}{c}\text { GLUT-4 } \\
\text { (adipogenic) }\end{array}$} & Forward & 5'-ATG TTG CGG AGG CTA TGGG-3' \\
\hline & Reverse & 5'-AAA GAG AGG GTG TCC GGT GG-3' \\
\hline \multirow{2}{*}{$\begin{array}{c}\text { MyoD } \\
\text { (myogenic) }\end{array}$} & Forward & 5'-CAC TAC AGC GGC GAC TCC-3' \\
\hline & Reverse & 5'-TAG GCG CCT TCG TAG CAG-3' \\
\hline \multirow{2}{*}{$\begin{array}{c}\text { GATA-4 } \\
\text { (myogenic) }\end{array}$} & Forward & 5'-GGA AGC CCA AGA ACC TGA AT-3' \\
\hline & Reverse & 5'-GTT GCT GGA GTT GCT GGA A-3' \\
\hline \multirow{2}{*}{$\begin{array}{c}\text { OPN } \\
\text { (osteogenic) }\end{array}$} & Forward & 5'-AGC TGG ATG ACC AGA GTG CT- 3' \\
\hline & Reverse & 5'-TGA AAT TCA TGG CTG TGG AA -3' \\
\hline \multirow{2}{*}{$\begin{array}{c}\text { OCN } \\
\text { (osteogenic) }\end{array}$} & Forward & 5'-CAG CGA GGT AGT GAA GAG ACC-3' \\
\hline & Reverse & 5'-TCT GGA GTT TAT TTG GGA GCA G-3' \\
\hline \multirow{2}{*}{$\begin{array}{c}\text { SOX-9 } \\
\text { (chondrogenic) }\end{array}$} & Forward & 5'-AGA CAG CCC CCT ATC GAC TT-3' \\
\hline & Reverse & 5'-CGG CAG GTA CTG GTC AAA CT-3' \\
\hline \multirow{2}{*}{$\begin{array}{l}\text { Collagen type II } \\
\text { (chondrogenic) }\end{array}$} & Forward & 5'-GTG AAC CTG GTG TCT CTG GTC-3' \\
\hline & Reverse & 5'-TTT CCA GGT TTT CCA GCT TC-3' \\
\hline \multirow{2}{*}{$\begin{array}{c}\text { GAPDH } \\
\text { (house-keeping) }\end{array}$} & Forward & 5'-ACC CAG AAG ACT GTG GAT GG-3' \\
\hline & Reverse & 5'-TTC TAG ACG GCA GGT CAG GT-3' \\
\hline
\end{tabular}




\subsection{Statistical Analysis}

Results are shown as average \pm standard deviation and were analysed by one-way ANOVA. If treatment level differences were determined to be significant, pair-wise comparisons were performed using Tukey post hoc test. Statistically significant differences are indicated with ${ }^{*} \mathrm{P}<0.05$, ${ }^{* *} \mathrm{P}<$ 0.01 , and ${ }^{* * *} \mathrm{P}<0.001$ unless otherwise noted.

\subsection{References}

1. Huang ZM, Zhang YZ, Kotaki M, Ramakrishna S. A review on polymer nanofibers by electrospinning and their applications in nanocomposites Compos. Sci. Technol. 2003;63:2223.

2. Rasband WS. ImageJ U.S. National Institutes of Health, Bethesda, Maryland, USA, http://imagej.nih.gov/ij/1997-2012.

3. O'Connell B. 2002. Oval Profile Plot. Research Services Branch, National Institute of Mental Health, National Institute of Neurological Disorders and Stroke. Available from: http://rsbweb.nih.gov/ij/plugins/ovalprofile.html

4. Roduit, C. "AFM figures" 2010, www.freesbi.ch, Creative Commons Attribution.

5. Glaß M, Möller B, Zirkel A et al. Cell Migration Analysis: Segmenting Scratch Assay Images with Level Sets and Support Vector Machines. Pattern Recognition. 2012;45:3154. http://www2.informatik.unihalle.de/agprbio/mitobo/index.php/Main_Page.

6. Selinummi J, Seppälä J, Yli-Harja O, Puhakka JA. Software for quantification of labeled bacteria from digital microscope images by automated image analysis. Biotechniques. 2005;39:859. 



\section{Chapter 4. Cell morphology and adhesion}

\section{Summary}

Cell fate under different conditions is investigated in this chapter. First, the specific effect of the ventral substrate on cell morphology was studied. Then we addressed the role of the dorsal stimuli in cell morphology, cell adhesion and cell proliferation. To do so we used different material/protein combinations, seeking to correlate the properties of each stimulus with the specific cell behaviour. Cell morphology, adhesion and proliferation were studied for different sandwich conditions. Results were found to depend on the ability of cells to reorganise the layer of proteins at the material interface. Hence, cell fate can be tuned adsorbing FN on material surfaces with different properties. Besides we show that cell behaviour might not be only a consequence of integrin-mediated adhesion to the surrounding matrix but also of the mechanical input. Overall, sandwich-like microenvironments switched cell behaviour (cell adhesion, morphology and proliferation) towards 3D-like patterns, demonstrating the importance of this versatile, simple and robust approach to mimic cell microenvironments in vivo.

* Results presented in this chapter have been partially published in: Ballester-Beltrán J, Lebourg M, Rico P, Salmerón-Sánchez M. Dorsal and ventral stimuli in cell-material interactions: effect on cell morphology. Biointerphases. 2012, 1-4, 39 and Ballester-Beltrán J, Moratal D, Lebourg M, Salmerón-Sánchez M. Fibronectin-matrix sandwich-like microenvironments to manipulate cell fate. Biomater Sci., 2014, 2, 381-389 



\subsection{Introduction}

Cells in multicellular organisms are surrounded by the extracellular matrix (ECM), a complex fibrous matrix that provides mechanical support and specific biochemical and biophysical signals able to direct cell function. ${ }^{1-3}$ Since the natural habitat of most living cells is a tridimensional (3D) mesh surrounding them, culturing cells on bidimensional (2D) surfaces imposes an unnatural environment totally different from the natural ECM. Hence changes in cell behaviour as a way to self-adaptation to the situation occur. ${ }^{4,5}$

Cell adhesion within 3D environments has been documented to be an $\alpha_{5} \beta_{1}$ integrin-dependent process stimulated by the presence of FN fibrils within the ECM.6-8 To mimic this environment in vitro, we have used poly(ethyl acrylate) (PEA) as one of the material components of the sandwich system since this is able to direct the organisation of FN into physiological-like fibrils in a process called material-driven FN fibrillogenesis. ${ }^{9-11}$

Concretely, in this chapter we investigate the role of dorsal and ventral stimuli on cell morphology by using different material substrates. In the first part of the study the role of the ventral substrate was evaluated. To do so PEA was used as dorsal substrate while different ventral substrates were used: spincoated PEA (on which FN assembles spontaneously into fibrillar networks in a physiological way); ${ }^{9}$ glass (on which FN adsorbs loosely allowing cells to reorganise the FN at the material interface) ${ }^{12,13}$ and aligned electrospun PEA fibers (to study the role of topological cues within the sandwich-like culture). Then, in order to study the role of the dorsal substrates, cells seeded on 2D PEA were overlaid with either a film of PEA or poly(lactic acid) (PLLA; on which FN does not assemble into a fibrillar network and protein is loosely adsorbed).

As a widely studied model of cell adhesion and migration in 2D and 3D cultures, NIH3T3 fibroblasts were used. Such cells do not naturally display apical-basal polarity, thus allowing deciphering the effect of specific anchorage on either one or both sides and the influence of its 
temporal course. Cell morphology, focal adhesion assembly, the development of the actin cytoskeleton, integrin expression, the phosphorylation of focal adhesion kinase (pFAK) and cell proliferation via 5-bromo-2-deoxyuridine (BrdU) incorporation assay were studied. Results were found to be closer to the 3D environments than to the $2 \mathrm{D}$ and correlated with the ability of cells to reorganise the dorsal layer of fibronectin at the material interface, demonstrating the versatility of the system as a tool for studying cell biology.

\subsection{Materials and methods}

\subsubsection{Materials}

Figure 4.1 depicts the different materials and proteins used in this work. The materials production and characterisation was detailed in chapter 3 .

A

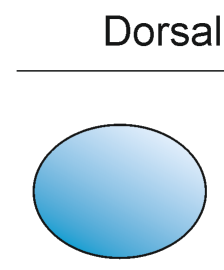

PEA

(Film)

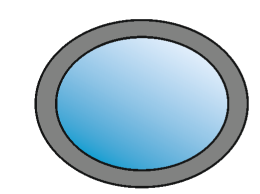

PLLA
Ventral Substrates

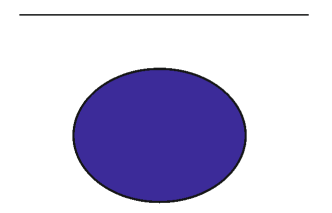

PEA, PEAa, Glass

(Solvent casted)

B
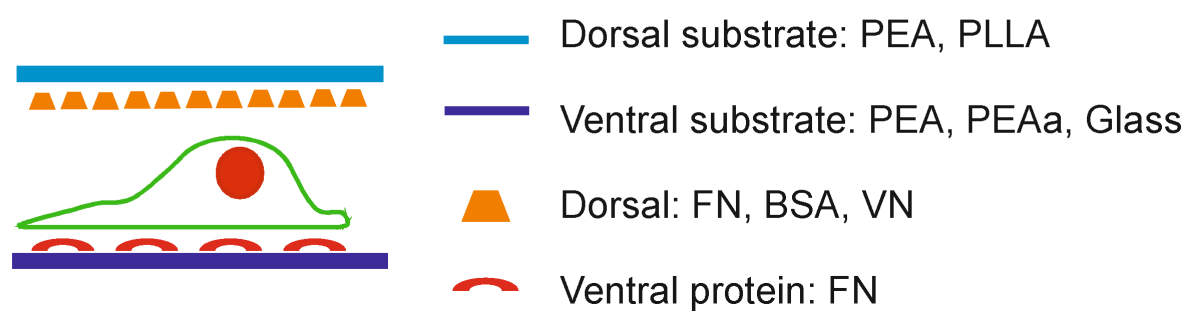

Figure 4.1. Sketch summarising the different conditions used in sandwich-like cultures. (A) Representation of the dorsal (film of PEA and solvent-casted PLLA) and ventral substrates (spin-coated PEA, aligned electrospun PEA fibers and glass coverslip) used in the sandwich-like culture. (B) Sketch of the sandwich-like model and the different combinations for each component (protein and material substrates). 


\subsubsection{Cell culture}

NIH3T3 fibroblasts (European Collection of Cell Cultures) were maintained in DMEM medium with 10\% Calf Serum (Thermo Scientific) and 1\% penicillin-streptomycin (Lonza). After UV sterilisation and protein coating, 7000 cells $/ \mathrm{cm}^{2}$ were seeded in serum free conditions on the different ventral surfaces.

For experiments including dorsal activation of cells seeded on 2D substrates, blocking antibodies or fibronectin were added after 5 min (t0) or $3 \mathrm{~h}$ of culture. Anti- $\alpha_{5}$ integrin antibody (CD 49e, clone SAM-01, Immunotech) was used at $1.2 \mu \mathrm{g} / \mathrm{mL}$ and $\mathrm{FN}$ at $50 \mu \mathrm{g} / \mathrm{mL}$.

\subsubsection{Biological characterisation}

Samples were fixed and observed in an inverted microscope. Thereafter morphology was quantified by calculating cell area and circularity.

Different immunofluorescences were carried out in sandwich cultures without "de-sandwiching" the constructs to preserve cell morphology. For cell adhesion experiments vinculin and actin were labeled so that focal adhesion and cytoskeleton were visualised. To check the ability of cells to reorganise the ventral FN, the immunodetection was carried out after $5 \mathrm{~h}$ of culture.

Finally FAKs and its phosphorylated forms at Tyr397 (pFAK), as well as $\alpha_{v}$ and $\alpha_{5}$ integrin subunits were evaluated by western blotting, and cell proliferation was evaluated based on the BrdU uptake during DNA synthesis in proliferating cells. For more detailed protocols please see chapter 3. 


\subsection{Results and discussion}

\subsubsection{Role of the ventral substrate in cell morphology}

In this section we evaluate cell response to different ventral substrates within the sandwich culture including spincoated PEA (PEAspc), aligned electrospun PEA fibers (PEAa) and glass; on which FN adsorbs to the material surface in different conformation and intensity (figure 4.2). ${ }^{9}, 12,13$ In order to ease the comparisons between the different conditions, PEA was always used as dorsal substrate.

Cell morphology was analysed in terms of spread area and circularity at 3 different time points: 3 hours (as a common point between 2D and SW but differing with $S^{t o}$ ), 6 hours (as initial cell response to the sandwich culture) and 24 hours (as late effect of the sandwich culture). To address the effect of the initial ventral material interaction before dorsal stimulation, sandwich-like cultures were established either immediately after cell seeding $\left(\mathrm{SW}^{t 0}\right)$ - to prevent any preferential role of ventral receptors - or after $3 \mathrm{~h}$ of $2 \mathrm{D}$ culture (SW), to permit initial cell adhesion on material surfaces using ventral receptors.

As a first step, cell viability within the sandwich-like system was checked at the longest time evaluated ( 24 hours) in order to rule out any diffusion problem of the culture medium through the system. As expected, most cells remain viable during the experiment (viability $>80 \%$ after $1 \mathrm{~d}$ of culture) since the top surface of the sandwich construct, a film of PEA, is a permeable material with a diffusion coefficient of water $D \sim 3.4 \cdot 10^{7}$ $\mathrm{cm}^{2} / \mathrm{s}^{14}$ 


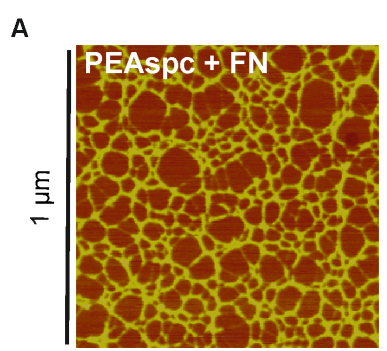

Figure 4.2. Material characterisation.
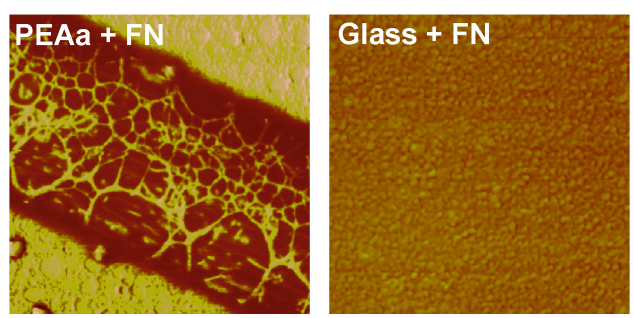

B

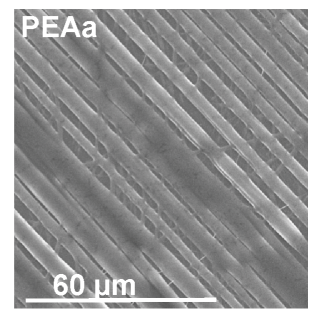

substrates surfaces as observed by AFM: fibrillar on PEA and globular on glass and PLLA. Similar FN-network was found on spin-casted and electrospun PEA. (B) Morphology of aligned PEA fibers as observed by SEM.

\section{Effect of ventral FN fibrils on cell morphology}

As previously commented, cell adhesion whitin 3D environments has been documented to be an $\alpha_{5} \beta_{1}$ integrin-dependent process stimulated by the presence of FN fibrils within the ECM.6-8 Hence, in our first study, we used FN-coated PEA for both dorsal and ventral stimulation as FN spontaneously organises into interconnected physiological-like fibrils on this material upon adsorption (figure 4.2A). The resulting fibrillar FN structure on PEA recapitulates the native structure of FN matrices and displays enhanced biological activity. ${ }^{9,15}$

Figure 4.3 shows representative images for cell morphology when cultured under this sandwich conditions. Overall, it is observed that, regardless the sandwich condition, cells spread less (in terms of area) compared with the 2D control $(\mathrm{p}<0.05$ for all conditions). Since cell volume is not expected to suffer important changes, this behaviour is likely to involve cell spreading in the z-direction rather than flat spreading as it happens on 2D substrates. ${ }^{16}$ Moreover cell circularity is altered for $\mathrm{SW}^{t} 0$ where cells adopted a rounded morphology whereas no significant differences with the corresponding controls are seen for SW. Nevertheless, results suggest cells cultured within sandwich SW tend to evolve towards a more rounded morphology since circularity increases during the culture (compare SW 6h and SW 24h). That is to say that once the cell has started the ventral adhesion process, cell spreading on the material surface provokes morphological changes that are only partially reversible upon 
dorsal stimulation. Hence, different ratio of dorsal-ventral contact (SW v $\mathrm{SW}^{t 0}$ ), give raise to quite different morphological parameters.
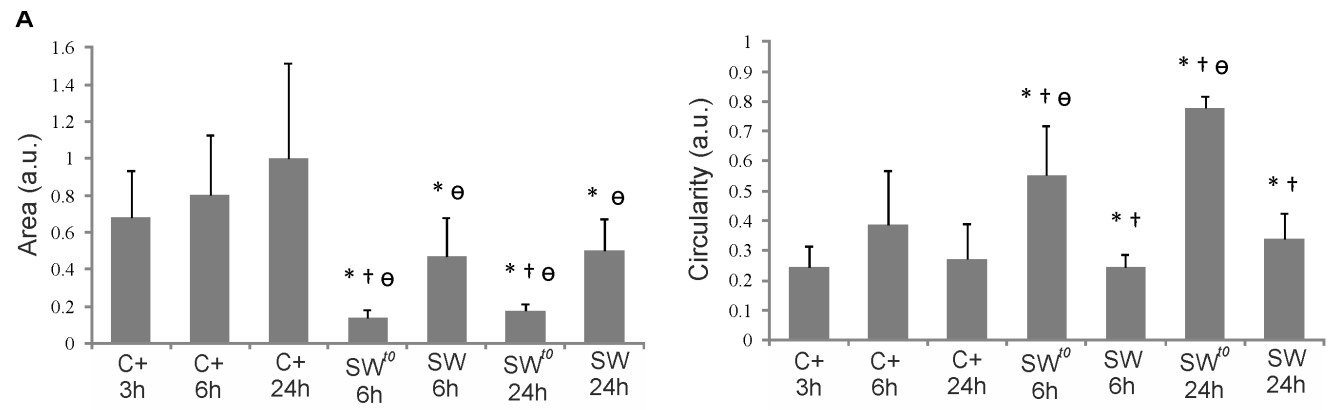

B

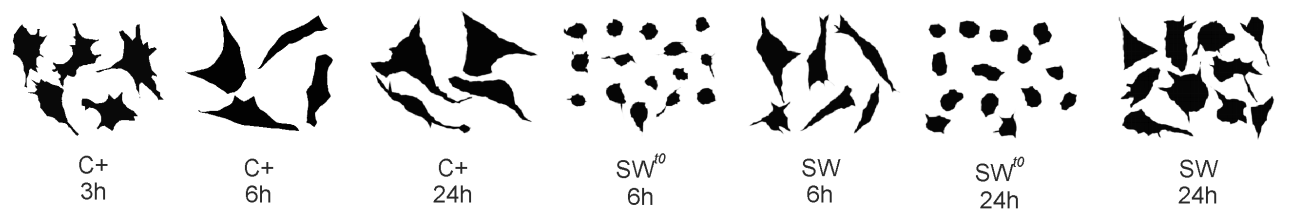

Figure 4.3. Cell morphology under sandwich culture involving FN-PEAspc as ventral and FN-PEA film as dorsal substrates. (A) Cell area and circularity. (B) Representative cells outlined from contrast phase microscopy for each one of the conditions. * shows significance of SW with SWto comparing among equal total culture times (i.e. cells cultured in SW $6 \mathrm{~h}$ and SWto $6 \mathrm{~h}$ adhere similarly on the ventral FN-coated substrate but not to the upper substrate), $\dagger$ for the significance of each condition during the culture (i.e. SW 6h and SW 24h) and $\Theta$ shows significance comparing with the control for the same culture time.

\section{Effect of ventral topological cues on cell morphology}

Seeking to quantify the influence of ventral versus dorsal stimuli, we have investigated cell behaviour in an asymmetric system. Here the plane PEA film remains as the dorsal stimulus but cells receive topological inputs from the ventral side since the FN network has been assembled on electrospun PEA fibers (figure 4.2).

As shown in figure 4.4, cells tend to align and spread rapidly under the strong geometrical input coming from the fibers (C+ PEAa). Actually, cells on the control 2D substrate aligned after only $3 \mathrm{~h}$ and circularity does not change anymore as a function of time. However our results show that, upon dorsal stimulation, cells do not continue the interaction with the 
underlying fibers as in the 2D situation. ${ }^{17}$ So, this experiment suggests that signaling coming from the dorsal stimuli diminishes the strength of the inputs coming from the ventral topological cues since cells are not able to align according to the ventral fibers if the sandwich is assembled from the very beginning $\left(\mathrm{SW}^{t 0}\right)$. By contrast, cells remain in a rounded-like morphology, with high circularity regardless the underlying ventral topological cues similarly as seen before. Moreover, even when ventral adhesion on the electrospun fibers is allowed for $3 \mathrm{~h}$ before dorsal stimulation (SW), more rounded cells are equally obtained suggesting a ventral-dorsal input competition.
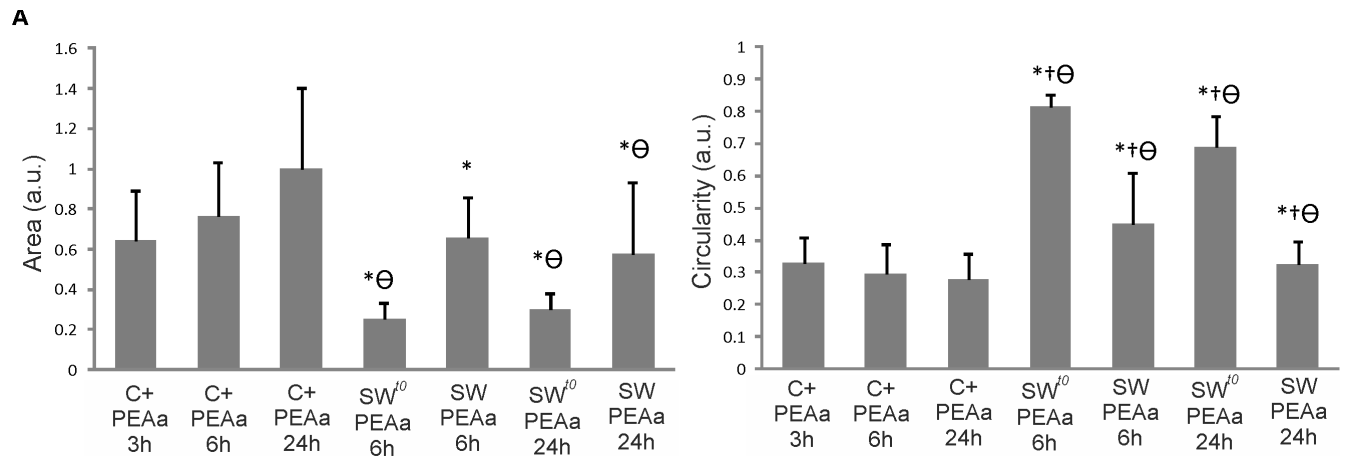

B
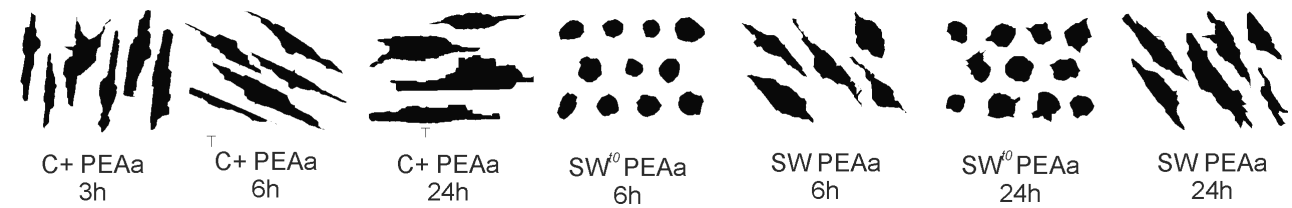

Figure 4.4. Cell morphology under sandwich culture with electrospun PEA fibers coated with FN as ventral substrate and FN-PEA film as dorsal substrates. (A) Cell area and circularity. (B) Representative cell morphologies for each one of the conditions. * shows significance of SW with SWto comparing among equal total culture times (i.e. cells cultured in SW $6 \mathrm{~h}$ and SWt0 $6 \mathrm{~h}$ ), $\dagger$ for the significance of each condition during the culture (i.e. SW 6h and SW 24h) and $\theta$ shows significance comparing with the control for the same culture time. 


\section{Effect of FN reorganisation at the ventral material interface on cell morphology}

We intend then to investigate whether the strength of the protein-material interaction confers additional degrees of freedom for cells cultured within the sandwich construct. To do so we used FN-coated glass as the ventral surface. Hydrophilic glass is known to be a material surface on which FN adopts a globular-like conformation (figure 4.2A), in such a way, that the strength of interaction between the material surface and the protein is low enough for cells to reorganise the adsorbed FN layer at the cell-material interface contrary to what happens with PEA. This can be seen in figure 4.5 were cells on PEA cannot reorganise the layer of FN into new fibrils. ${ }^{18}$
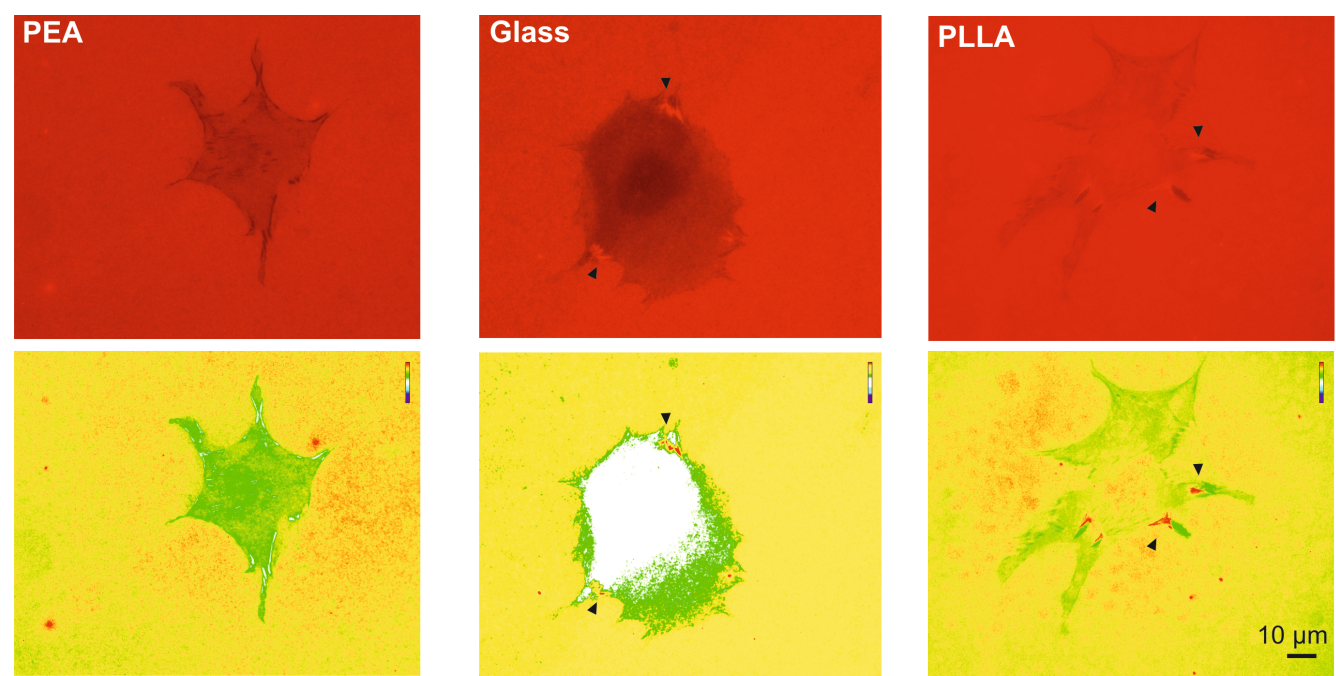

Figure 4.5. Fibronectin reorganisation on 2D PEAspc, glass and PLLAspc samples after 5 hours of culture. Fluorescence staining for fibronectin is shown in red in the first arrow. Images in the second arrow represent the heat maps for fibronectin reorganisation and fibril formation. Black arrowheads point out reorganised fibronectin in new fibrils (brighter areas).

Similarly as seen before, upon simultaneous dorsal and ventral stimulation $\left(\mathrm{SW}^{t 0}\right)$, cells remained less spread (lower area) and with higher circularity than the 2D control. In the case of SW, cells have significantly lower areas at all times, but circularity is reduced and not different from controls, neither it rises with time as was the case in the ventral PEAspc sandwiches (figure 4.6). Hence, as before, cells are 
somehow frozen in after receiving dorsal stimuli, even if the underlying surface (FN on glass) is now much more mobile.

A
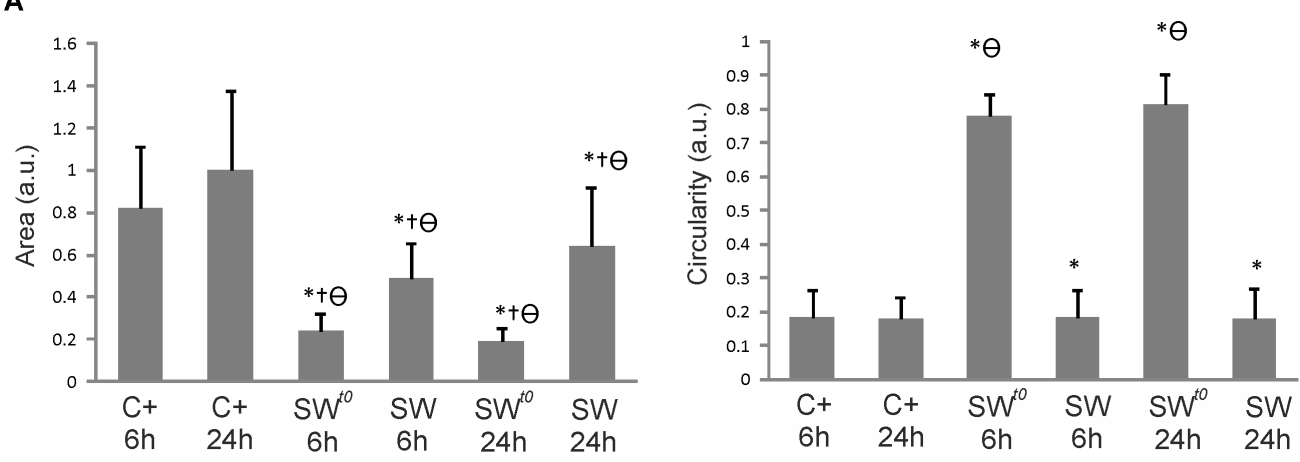

B

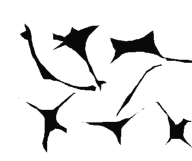

C+ Glass $6 \mathrm{~h}$

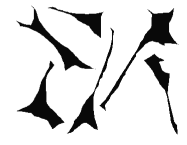

C+ Glass $24 \mathrm{~h}$

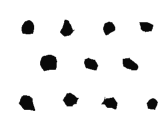

SW $^{t 0}$ Glass $6 \mathrm{~h}$

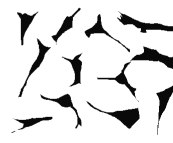

SW Glass

$6 \mathrm{~h}$

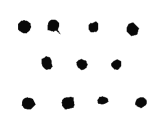

SW $^{\text {to }}$ Glass $24 \mathrm{~h}$

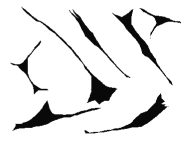

SW Glass $24 \mathrm{~h}$

Figure 4.6. Cell morphology within sandwiches including FN-Glass (ventral) and FN-PEA film (dorsal). (A) Cell area and circularity. (B) Representative cells outlined for each one of the conditions as shown by contrast phase microscopy. * shows significance of SW with SWto comparing among equal total culture times (i.e. cells cultured in SW $6 \mathrm{~h}$ and SWto $6 \mathrm{~h}$ adhere similarly on the ventral FNcoated substrate but not to the upper substrate), $\dagger$ for the significance of each condition during the culture (i.e. SW $6 \mathrm{~h}$ and SW $24 \mathrm{~h}$ ) and $\theta$ shows significance comparing with the control for the same culture time.

\subsubsection{Effect of non-adhesive dorsal contact on cell morphology}

We have shown the preferential role that dorsal stimulation plays on the cell-material interaction regardless the nature of the ventral interaction. We want now to clarify whether this phenomenon is a consequence of a biological cell-protein-material interaction or, by contrast, its origin must be sought as a mere physical interaction. To do so, we have used bovine serum albumin (BSA) to coat the dorsal PEA film (instead of FN) since it is a non-adhesive protein on which cells cannot adhere and spread by integrins. As a consequence cells on 2D BSA-coated materials remain in a rounded-like morphology (see $\mathrm{C}+3 \mathrm{~h}$ BSA in figures 4.7B and 4.8B). ${ }^{19-21}$ 
To further characterise cell behaviour, experiments were done using both FN-coated glass and FN assembled fibrils on PEAspc as substrates for ventral cell adhesion. When seeded on FN-coated PEA as ventral substrate, even if cells cannot adhere to the dorsal BSA-coated material, their behaviour did not follow the expected one for cells spreading on a 2D material surface (where there is no biological dorsal stimulation since cells can adhere only to the FN coated ventral substrate). Had this happened, both spread area and circularity should be the same for cells within the sandwiches and the 2D controls, which is not the case (figure 4.7). Moreover, cells within sandwich SW should behave as in sandwich SWto, since both situations involve the same hours of ventral interaction without any biological dorsal stimulation.
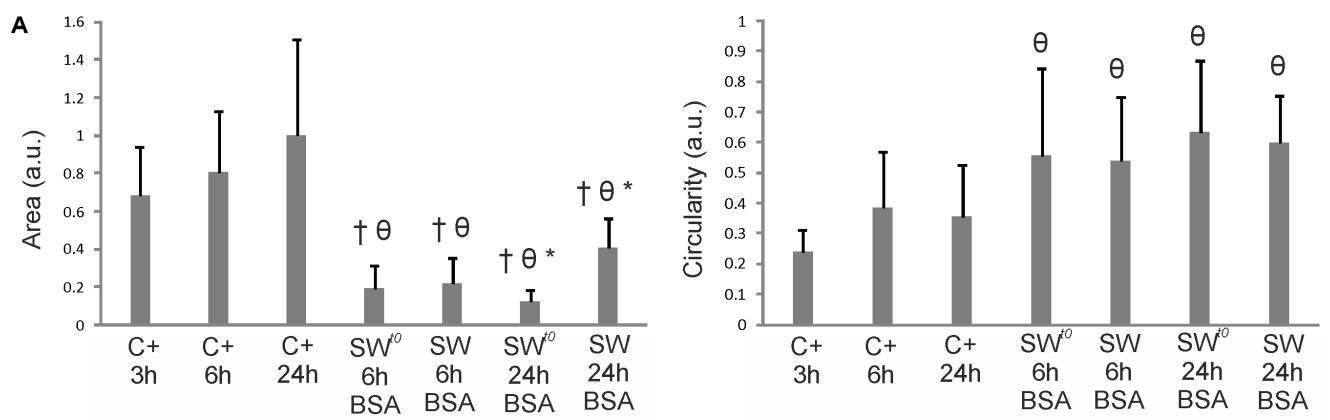

B

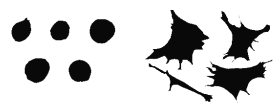

$\mathrm{C}+3 \mathrm{~h} \mathrm{BSA} \quad \mathrm{C}+3 \mathrm{~h} \mathrm{FN}$

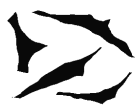

$\mathrm{C}+6 \mathrm{~h} \mathrm{FN}$

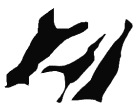

$\mathrm{C}+24 \mathrm{~h} \mathrm{FN}$

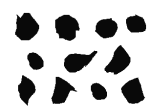

$\mathrm{SW}^{\text {to }} 6 \mathrm{~h}$ BSA

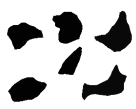

SW 6h BSA

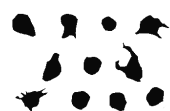

$\mathrm{SW}^{\mathrm{t}} 24 \mathrm{~h}$ BSA

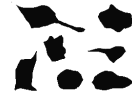

SW 24h

Figure 4.7. Results for sandwiches including FN-PEAspc (ventral) and BSA-PEA film (dorsal). (A) Cell area and circularity for each condition. (B) Representative cells outlined from contrast phase microscopy images. * shows significance of SW with $\mathrm{SW}^{t 0}$ comparing among equal total culture times (i.e. cells cultured in SW $6 \mathrm{~h}$ and $S W^{t 0} 6 \mathrm{~h}$ ), $†$ for the significance of each condition during the culture (i.e. SW $6 \mathrm{~h}$ and SW 24h) and $\theta$ shows significance comparing with the control for the same culture time. 
The situation is slightly different when cells are seeded on FNcoated glass as the ventral surface (figure 4.8). In this case, even if values do not reach the 2D situation, cells spread more than if FN were used as dorsal stimuli (compare with figure 4.6). Correspondingly, cell circularity remains similar for every condition (sandwich or 2D) and much lower than for those sandwiches with FN as the dorsal interacting protein, where true dorsal biological stimuli (integrin-mediated) must occur (figure 4.8).
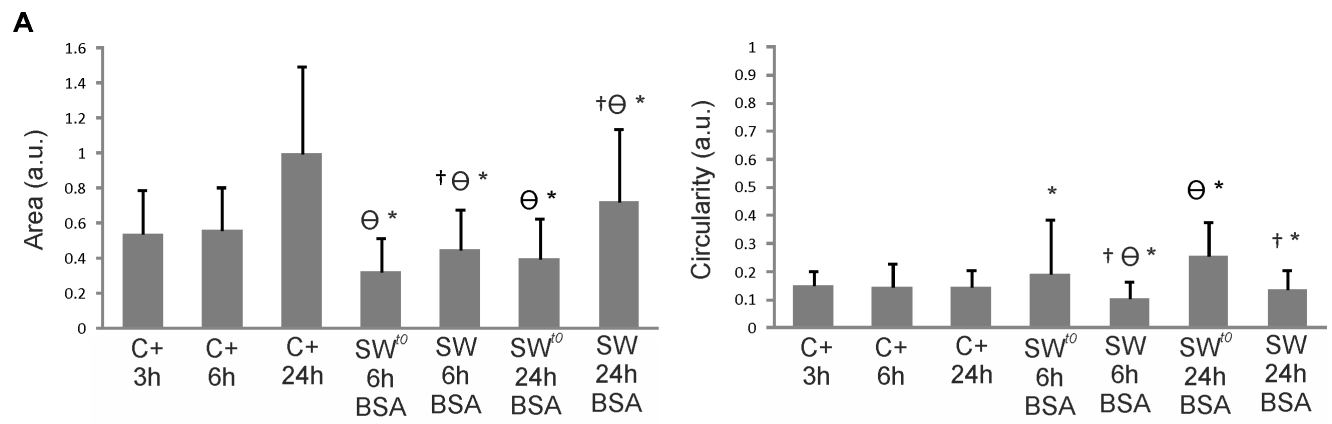

B

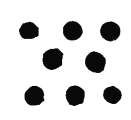

C+ BSA

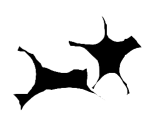

$\mathrm{C}+3 \mathrm{~h} \mathrm{FN}$

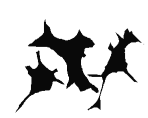

$\mathrm{C}+6 \mathrm{~h} \mathrm{FN}$

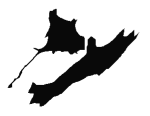

$\mathrm{C}+24 \mathrm{~h} \mathrm{FN}$

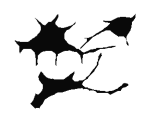

$\mathrm{SW}^{\text {to }} 6 \mathrm{~h}$ BSA

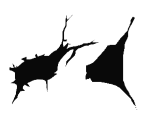

SW 6h

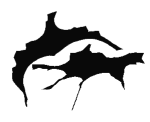

$\mathrm{SW}^{\text {to }} 24 \mathrm{~h}$

BSA

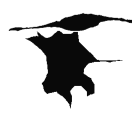

SW 24h BSA

Figure 4.8. (A) Cell area and circularity for cells within sandwiches including FNGlass as ventral substrate and BSA-PEA film as dorsal substrates. (B) Representative cells outlined for each one of the conditions. ${ }^{*}$ shows significance of SW with SWto comparing among equal total culture times (i.e. cells cultured in SW $6 \mathrm{~h}$ and SW $\mathrm{SW}^{t 0} 6 \mathrm{~h}$ ), $\dagger$ for the significance of each condition during the culture (i.e. SW $6 \mathrm{~h}$ and SW 24h) and $\Theta$ shows significance comparing with the control for the same culture time.

The role of merely dorsal physical stimuli is therefore strongly linked to the properties of the surface on which cells interact ventrally. So, the ability of cells to reorganise the ECM as well as the dimensionality (and thus the dorsal mechanical input) play a key role in cell morphology when cultured in a closer 3D environment. 


\subsubsection{Cell fate within sandwich culture with different dorsal stimulation}

The ability to reorganise the ventral FN was shown to influence cell morphology (when BSA was used as dorsal protein coating and glass/PEA coated with FN as ventral substrate, figures 4.7 and 4.8). As this fact was observed using PEA as a dorsal stimulus and varying the ventral substrate, we wanted to inquire now about the influence of dorsal protein remodelling on cell fate in sandwich cultures. To this end, we performed sandwich cultures where the ventral substrate was kept throughout all the experiments (PEAspc) and the dorsal one varied.

The effect of the dorsal substrate on cell fate was characterised in terms of cell morphology, adhesion and its triggered downstream signalling since, notwithstanding controversial results and discussions, ${ }^{22,23}$ it is well accepted that cells both in vivo and within 3D in vitro cultures do not develop focal adhesions as they do on 2D substrates. Rather, cells organise randomly distributed 3D matrix adhesions with increased intra-cytoplasmatic labeling, ${ }^{24}$ different molecular composition and broader distribution of sizes, ${ }^{6,25}$ revealing the key role of dimensionality in cell adhesion and signalling. ${ }^{26}$

\section{Cell fate when FN-PEA film was used as dorsal substrate}

As commented before, cell adhesion whitin 3D environments has been documented to be an $\alpha_{5} \beta_{1}$ integrin-dependent process stimulated by the presence of FN fibrils within the ECM. ${ }^{6-8}$ Hence we studied cell fate under sandwich culture using FN-coated PEA for both dorsal and ventral stimulation in order to mimic these physiological-like fibrils.

As expected, mature actin fibers inserted into well-defined focal adhesions (vinculin) were found on the 2D controls (both the ventral spin casted PEA (C+); and the dorsal film of PEA). Contrary, within sandwich cultures vinculin is not organised into focal plaques but remains homogenously distributed throughout the cytoplasm (figure 4.9). Accordingly, the actin cytoskeleton is not completely developed and only a peripheral staining is shown, which is characteristic of early stages of actin polymerization ${ }^{27}$ and reported for other 3D systems. ${ }^{24,28}$ The altered 
cell morphology observed in these sandwich conditions is then correlated with the poor cell adhesion, as has been reported for other 3D matrices both in vitro and in vivo. ${ }^{17,25,26}$
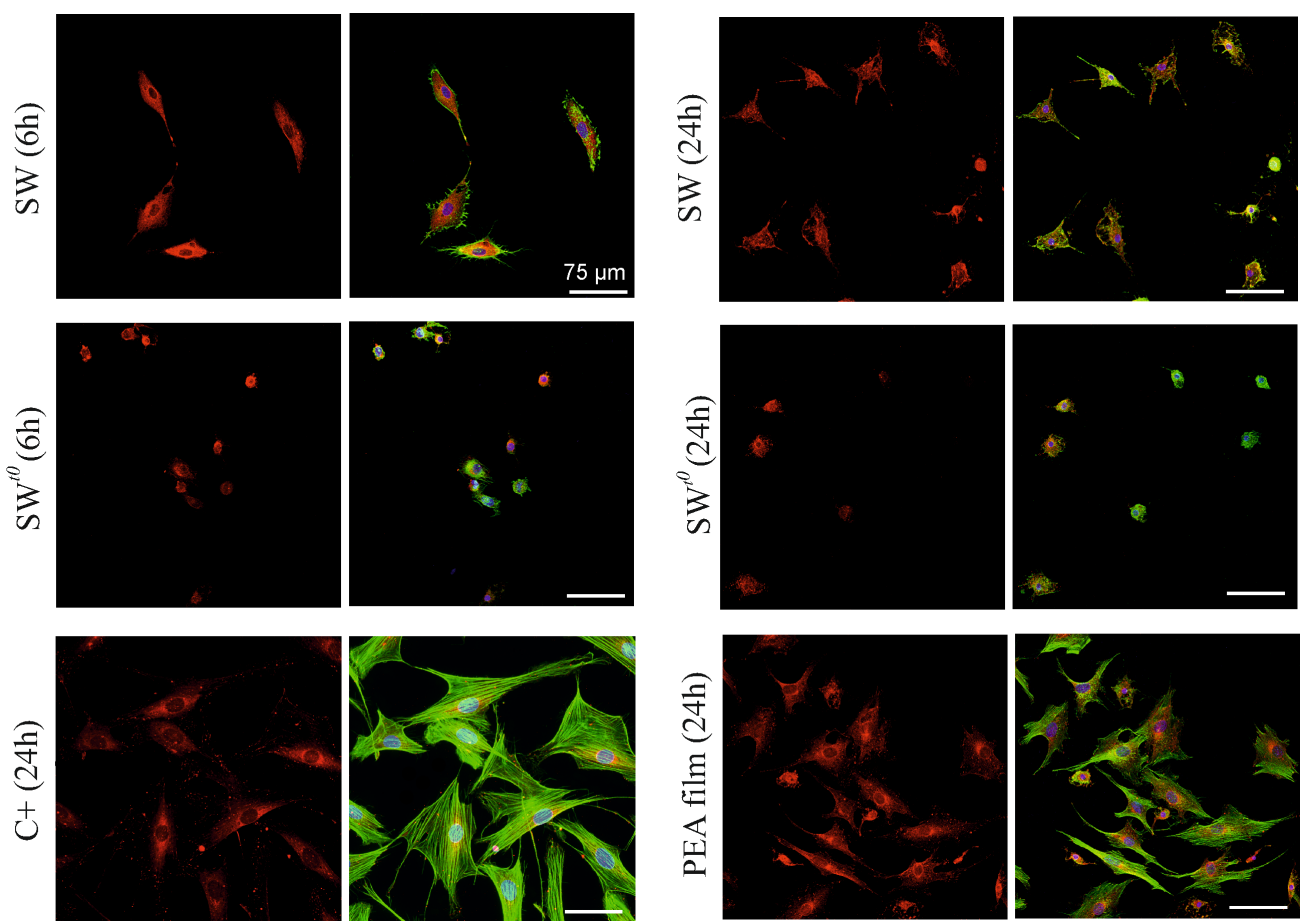

Figure 4.9. Cytoskeleton organisation and focal adhesion formation on 2D controls and sandwich cultures (with both dorsal and ventral interfaces consisting of FN fibrils assembled on PEA). Fluorescence images show vinculin (red), F-actin cytoskeleton (green) and nuclei (blue).

Since $\alpha_{5} \beta_{1}$ and $\alpha_{v} \beta_{3}$ integrins are the main FN receptors, ${ }^{29}$ we quantified $\alpha_{5}$ and $\alpha_{v}$ integrin subunits for different sandwich conditions after 6 hours of culture. As shown in figure 4.10, higher $\alpha_{5}$ levels were found for cells within both sandwich conditions (SW and SW ${ }^{t 0}$ ), which suggest altered cell adhesion compared to the control 2D culture. Although the highest $\alpha_{5}$ level was obtained for cells dorsally and ventrally stimulated from the very beginning of the culture $\left(\mathrm{SW}^{t 0}\right)$, it is remarkable that further increase in integrin expression also occurs if cells are dorsally stimulated after $3 \mathrm{~h}$ of ventral adhesion (SW). Differences in integrin expression between SW and SW ${ }^{t 0}$ might be sought in the duration of the dorsal stimuli and/or the existence of a "ventral memory" for SW 
conditions (3h-2D +3 h-sandwich). Importantly, higher $\alpha_{5}$ integrin levels within sandwich cultures are not merely a consequence of the higher surface available for cell contact (dorsal and ventral), as no differences in $\alpha_{v}$ integrin were detected (figure 4.10B). Hence this result supports the claim that cells in sandwich-like systems behave closer to $3 \mathrm{D}$ environments, where cell adhesion has been shown to be mostly $\alpha_{5} \beta_{1}$ dependent. 6,30

A

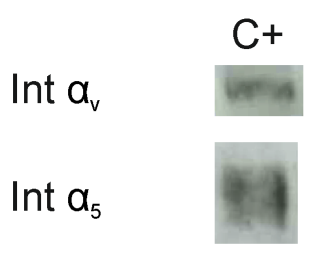

B

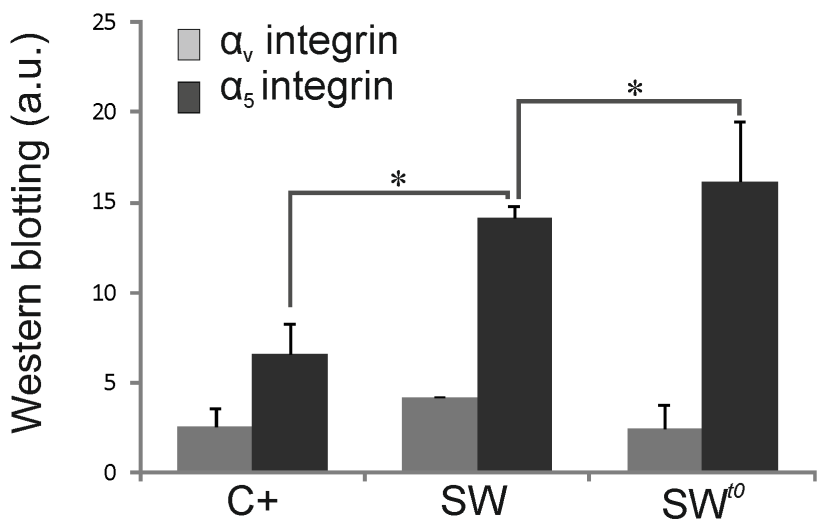

C

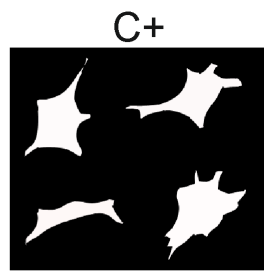

SW

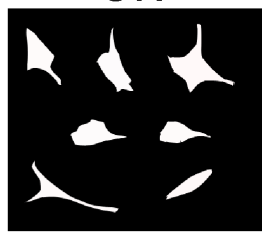

$\mathrm{SW}^{\text {to }}$

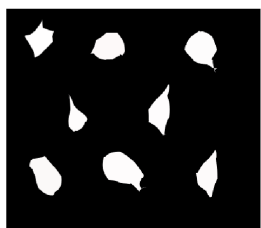

Figure 4.10. Integrin quantification for $\alpha_{5}$ and $\alpha_{\mathrm{v}}$ subunits, major fibronectin receptors, after $6 \mathrm{~h}$ of culture. (A) Representative western blot bands for $\alpha_{5}$ and $\alpha_{v}$ integrin subunits. (B) Quantification of $\alpha_{v}$ and $\alpha_{5}$ integrin subunits. (C) Representative outlined cells from contrast phase microscopy for each one of the conditions. * stands for $\mathrm{P}<0.05$. 
After ligand binding, integrins cluster and develop focal adhesion complexes that link the extracellular matrix with the actin cytoskeleton and direct the subsequent cellular response by triggering the phosphorylation of different signalling proteins. FAK is a key signalling protein contributing to integrin control of cell motility, invasion, survival, and proliferation (see figure 1.1). ${ }^{31}, 32$ Since differences in integrin expression were detected, we wonder now whether the dorsal stimuli within the sandwich microenvironments alters FAK phosphorylation and thus its signalling pathway. Figure 4.11 shows that phosphorylation of FAK ${ }^{\mathrm{Ty}} 397$ is enhanced when dorsal stimuli are applied after $3 \mathrm{~h}$ of ventral adhesion (SW). This result reveals the difference between the simultaneous $\left(\mathrm{SW}^{t 0}\right)$ and sequential (after $3 \mathrm{~h}$ of 2D culture, SW) stimulation of dorsal and ventral receptors which might be sought as a consequence in the timing of the dorsal stimulation. Interestingly, when the level of FAK phosphorylation is normalized relative to $\alpha_{5}$ integrin expression, sandwich conditions obtain lower values compared to the equivalent 2D system, which suggests that even if $\alpha_{5}$ level is higher within sandwich systems (figure 4.10), these integrins are less effective in phosphorylating FAK (figure 4.11C) than in a 2D culture based on the same material/protein interface. Other activation processes such as growth factor receptor signalling or other $\beta_{1}$ integrins that bind FN could be related to this higher phosphorylation of FAK. However this is unlikely since our experiments were carried out in serum free conditions (thus without added growth factors) and it is well documented that $\alpha_{5} \beta_{1}$ is the main FN receptor. This result is also supported by the less effective integrin clustering into focal adhesions observed in these sandwich systems (figure 4.9). 


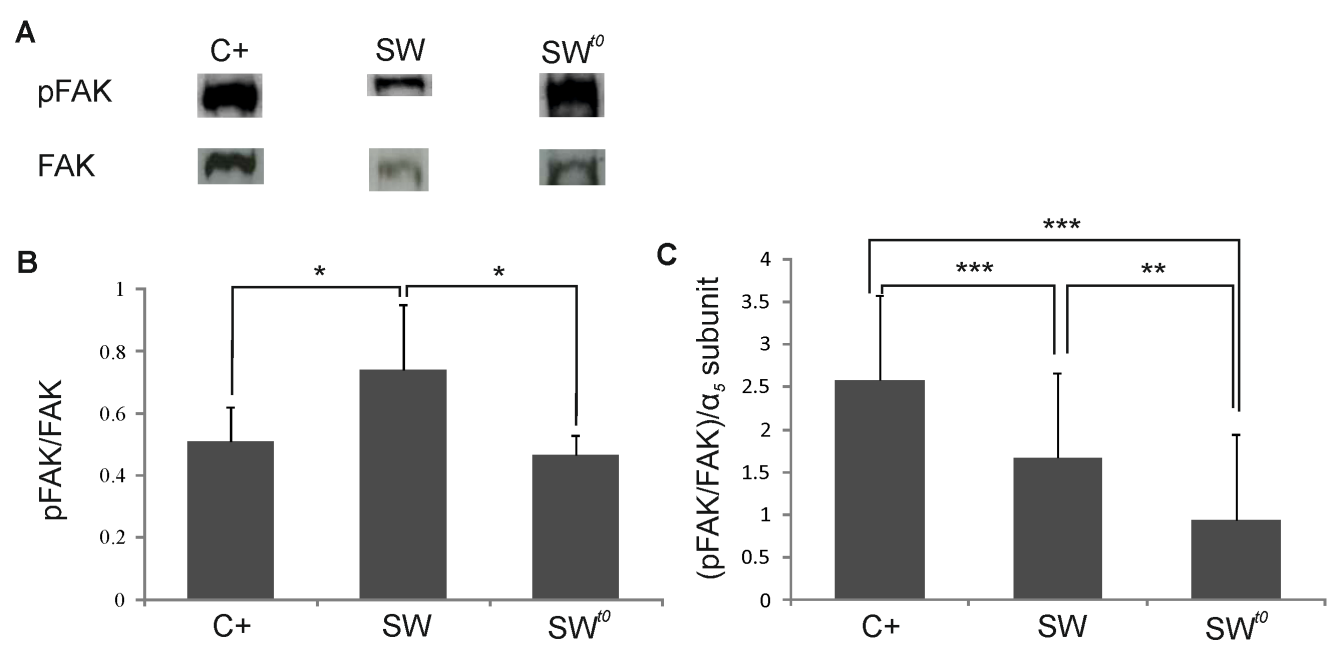

Figure 4.11. FAKs phosphorylation. (A) Representative western blot bands for phosphorylated tyrosine-397 residue on FAK and total FAK (pFAK and FAK respectively). (B) Quantification of the fraction of phosphorylated FAKs by image analysis of the western blot bands. (C) Normalised FAK activation relative to $\alpha_{5}$ integrin subunit expression. Error bars represent the standard deviation of three independent experiments. * stands for $\mathrm{P}<0.05$, ${ }^{* *}$ for $\mathrm{P}<0.01$ and ${ }^{* * *}$ for $\mathrm{P}$ $<0.001$.

FAK signalling is a key pathway linking cell adhesion to cell proliferation, cell motility and cytoskeleton reorganisation. We have already seen the assembly of the actin cytoskeleton is altered within sandwich microenvironments (figure 4.9) so we wondered if more pathways were disregulated. Cell proliferation after 6 and $24 \mathrm{~h}$ of culture was therefore addressed by the bromodeoxyuridine uptaking assay. As shown in figure 4.12A, cell proliferation for both 2D and sandwich microenvironments was similar after $6 \mathrm{~h}$ of culture, but significantly lower within sandwich conditions after $24 \mathrm{~h}$, as reported to occur in vivo. ${ }^{33}$ Smaller but significant differences can be also observed after 24 hours in dependence of whether the sandwich was assembled immediately (SW ${ }^{t 0}$ ) or after $3 \mathrm{~h}$ of culture (SW).

To clarify the role of dorsal adhesion in cell proliferation, the integrin binding site of fibronectin was blocked (with HFN7.1 antibody) on the dorsal substrate before sandwiching. HFN7.1 binds to the flexible linker between the $9^{\text {th }}$ and $10^{\text {th }}$ type III repeats of FN where the RGD and 
synergy sequences are located. ${ }^{34}$ Figure $4.12 \mathrm{~B}$ shows a slightly increase in cell proliferation after blocking (SW ${ }^{t 0}+$ HFN7.1) that is not statistically significant in SW environments ( $3 \mathrm{~h}$ dorsal $+3 \mathrm{~h}$ ventral). Blocking RGD domains of dorsal FN - and therefore limiting dorsal integrin binding -35 does not restore cell proliferation to the levels observed in 2D cultures. In addition, had this happened, cell morphology should be the same for cells within the sandwiches and the 2D controls, which is not the case (figure 4.12C). The same behaviour was previously observed when using BSA as a dorsal protein coating (figure 4.7). ${ }^{17}$ This suggests that altered proliferation within sandwich cultures is not directly a consequence of $\alpha_{5} \beta_{1}$ integrin-mediated adhesion with the dorsal substrate.

A

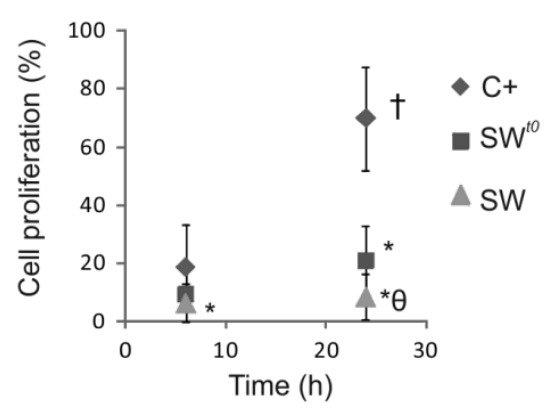

C

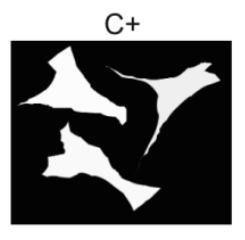

B

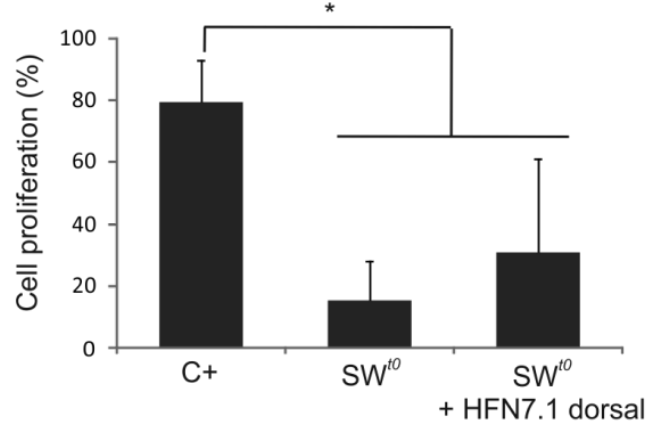

$\mathrm{SW}^{10}$

+ HFN7.1 dorsal
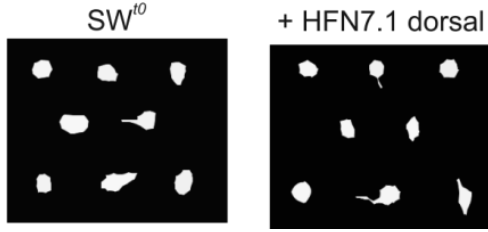

Figure 4.12. Cell proliferation within sandwich cultures. (A) Cell proliferation on the 2D substrate and the sandwich cultures. $\dagger$ stands for significant difference with time, $*$ differences with the control (same time) and $\theta$ differences with the sandwich assembled immediately after cell seeding. (B) Cell proliferation for culture conditions where HFN7.1 antibody was used to block the dorsal FN cell adhesion domain so that cells cannot use $\alpha_{5} \beta_{1}$ integrin to interact with the dorsal substrate. Total culture time $24 \mathrm{~h} .{ }^{*}$ stands for $\mathrm{P}<0.05$. (C) Representative outlined cells for each one of the conditions. 
To sum up, cells cultured within a sandwich with ventral and dorsal PEA interact with a FN network (ventrally and dorsally) and have their morphology, adhesion, signalling and proliferation altered if compared with the 2D condition. Previous works showed that cells cannot mechanically remodel (reorganise) this material-driven FN network (on 2D substrates) due to the strength of the protein-material interaction (see figure 4.5). ${ }^{36}$ In consequence, cells cultured on 2D PEA substrates, unable to reorganise FN, showed increased proteolytic activity and remodelled the provisional matrix by increasing the expression of MMPs. ${ }^{37}$ Consequences in sandwich culture might be more severe as cells need to interact with this FN matrix both on the ventral and dorsal side. Consequently cells are not able to spread properly and remain "frozen" in the attained morphology (rounded and smaller for SWto; smaller for SW) resembling cells in a non-degradable 3D hydrogels (figures 4.3 and 4.4). ${ }^{17}$

\section{Role of dorsal stimuli in cell fate}

One could concern if the conformation of the FN, rather than the ability of cells to reorganise the $\mathrm{FN}$, is the real cause of the differences seen in cell morphology. Actually, FN network on PEA could expose domains (cell binding domains, growth factor binding domains...) that might lead to this characteristic cell morpholgy and fate. In order to corroborate our hypothesis we sandwiched cells with 2 different dorsal substrates: (i) a film of PEA coated with vitronectin (VN), which not only triggers different cell adhesion than $\mathrm{FN}^{38,39}$ but besides adopts a different conformation on PEA (isolated globular-like conformation instead of as a network) ${ }^{38,40}$ and (ii) a film of poly (L-lactic acid) (PLLA) where FN adopts a globular conformation (figure 4.13) and, contrary to the case of PEA, can be mechanically reorganised upon cell adhesion due to the lower intensity of the protein-material interaction (figure 4.5). ${ }^{41}$ 

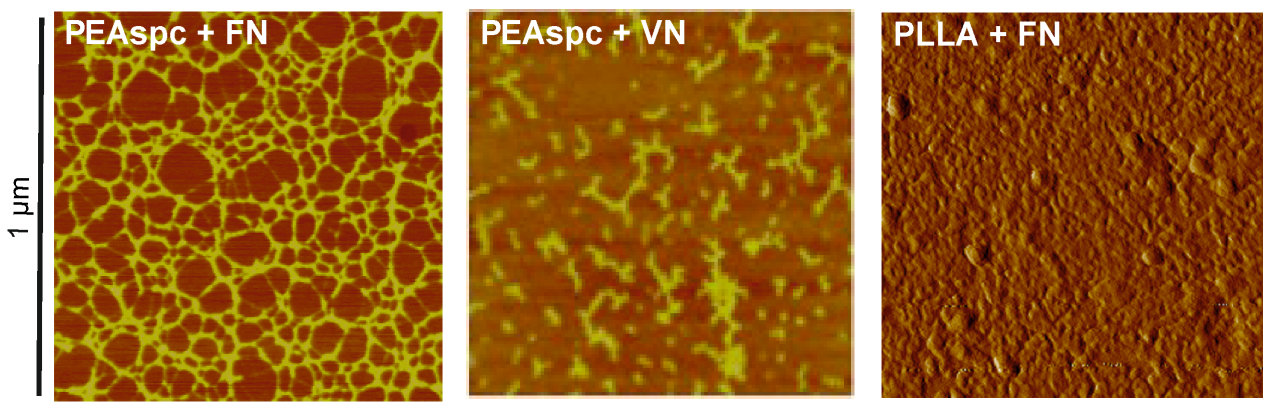

Figure 4.13. Protein distribution as observed by AFM. Fibronectin adopts network-like conformation on PEA and globular-like conformation on PLLA. Vitronectin adopts a globular-like conformation on PEA.

As can be seen in figure 4.14, cells sandwiched with PEA-VN adopted similar morphology (cell area and circularity) than those sandwiched with PEA-FN. Moreover, cell morphology was statistically different than those cells sandwiched with PLLA-FN, which were similar to the 2D control. That is to say, the strenght of the protein-material interaction (and not the protein conformation) might be the cause triggering this characteristic cell morphology within sandwich cultures. These results suggest therefore that cell morphology within sandwich culture is strongly influenced by the capacity of cells to reorganise the ECM, similarly as seen for hydrogels. We evaluated this observation is not a cell-dependent process since $\mathrm{C} 2 \mathrm{C} 12$ myoblasts cultured within sandwiches with ventral PEAspc and either FN-PEA or FN-PLLA as dorsal substrate got similar cell morphology (data not shown). 
A

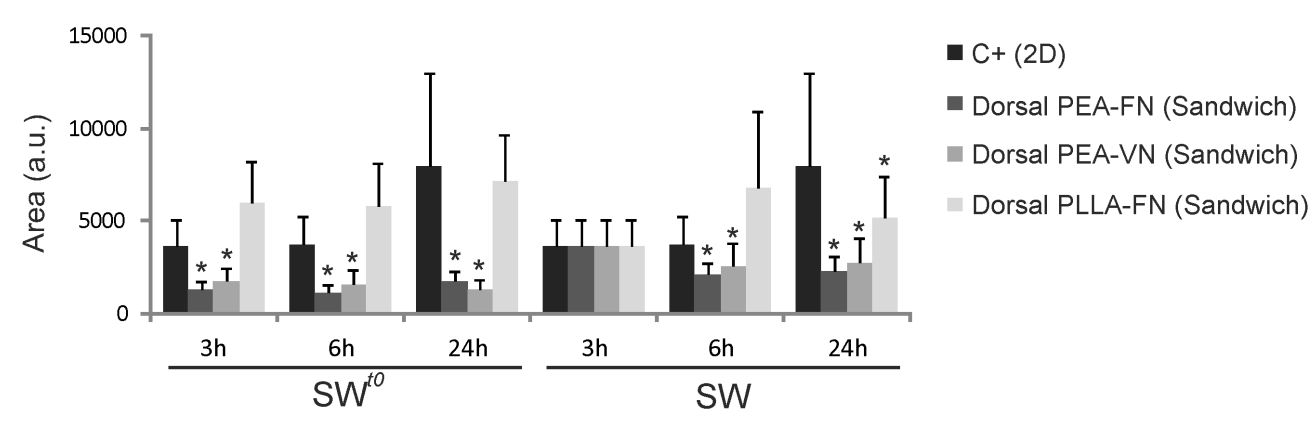

B

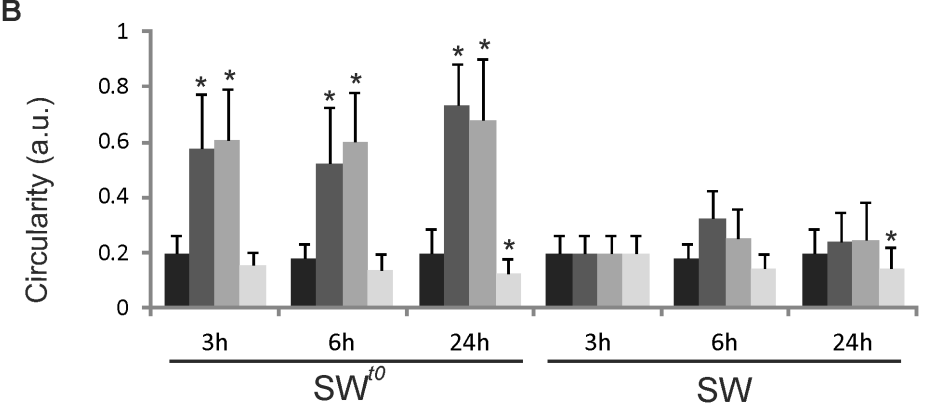

- $\mathrm{C}+(2 \mathrm{D})$

- Dorsal PEA-FN (Sandwich)

- Dorsal PEA-VN (Sandwich)

-Dorsal PLLA-FN (Sandwich)

C

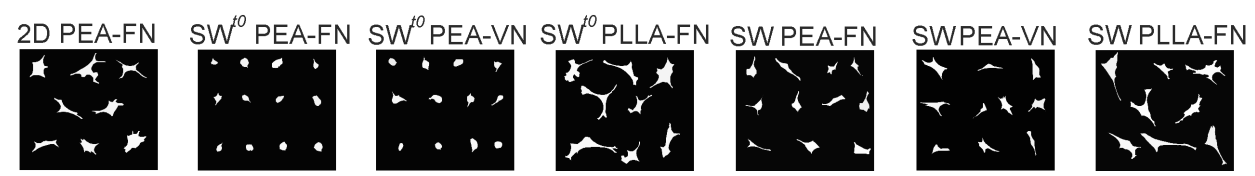

Figure 4.14. Cell morphology within sandwich cultures with different dorsal stimuli including sandwich with dorsal PEA-FN, PEA-VN and PLLA-FN. (A) Cell area and (B) cell circularity depend on the strength of the protein-material interaction. (C) Representative outlined cells from contrast phase microscopy for each one of the conditions at 6 hours of culture. ${ }^{*}$ stands for significant differences with the 2D control (same time) $\mathrm{P}<0.05$.

To further correlate the role of the mobility of the dorsal FN layer, we investigated cytoskeleton assembly and focal adhesion formation within sandwiches with dorsal FN-PLLA. Cells seeded within this sandwich showed a matured cytoskeleton inserted into well-defined focal adhesions, similarly as it is shown for 2D controls (figure 4.15) and unlike cells sandwiched within the sandwich involving dorsal FN-PEA (figure 4.9). 
As cell morphology is known to direct cell fate,42, 43 cell proliferation was also studied. The ability to reorganise dorsal FN was correlated with increased cell proliferation after 24 hours in PLLA sandwiches (note that this did not occur in FN-matrix PEA sandwiches; results are included in figure 4.16 to facilitate reading). Interestingly, cell proliferation with PLLA as dorsal substrate was still lower than on 2D controls where cells only need to reorganise proteins at the ventral plane. Hence, dorsal stimuli within sandwich cultures highly influence cell morphology, adhesion and proliferation; and correlates with the ability of cells to reorganise dorsal FN. In this way, similarly as cells within dorsal FN-PEA sandwiches resembled cells cultured in a non-degradable hydrogel (round morphology and absence of adhesion), cells seeded within sandwich cultures with dorsal PLLA resemble cells seeded in degradable hydrogels (spread cells with focal adhesion and higher proliferation rates), suggesting therefore that the ability of cells to reorganise the ECM directs cell fate in a similar way as it does in 3D hydrogels.
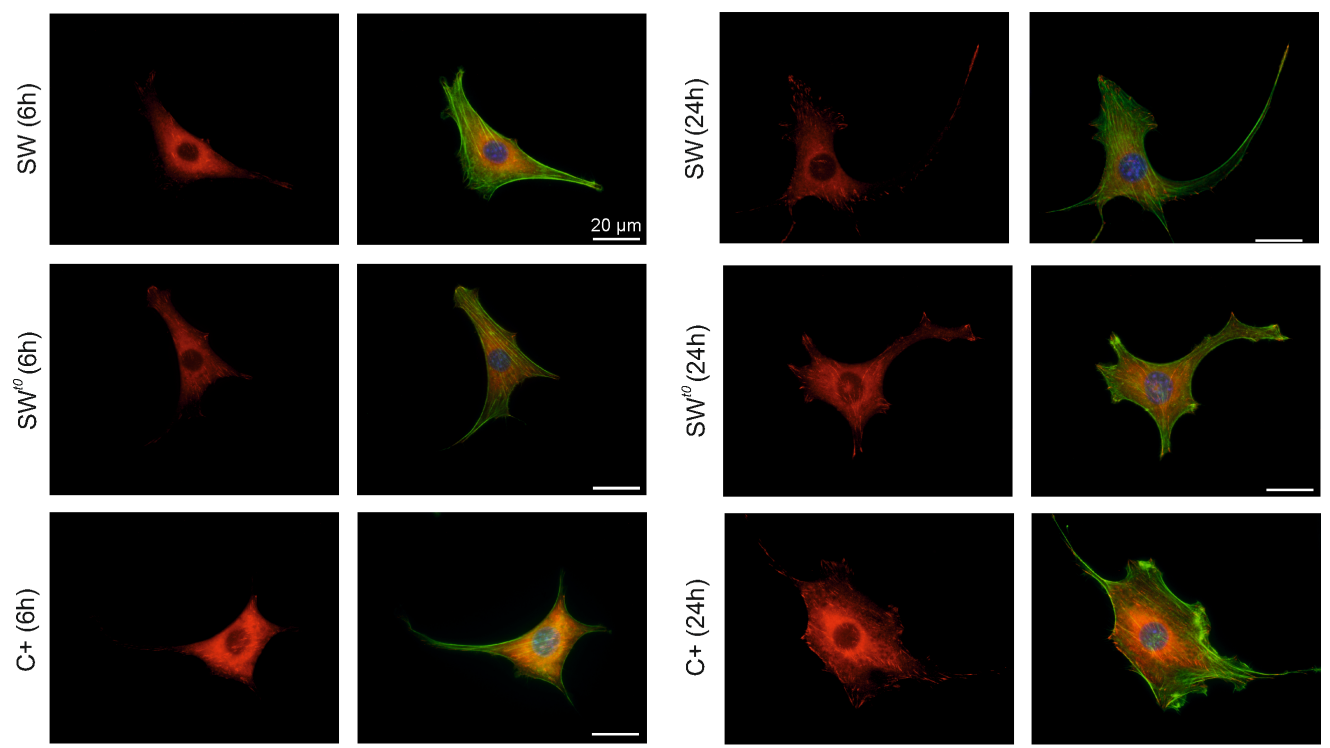

Figure 4.15. Cytoskeleton organisation and focal adhesion assembly for cells seeded on PEAspc (C+) and sandwiched with dorsal FN-coated PLLA. Fluorescence images show vinculin (red), F-actin cytoskeleton (green) and nuclei (blue). 


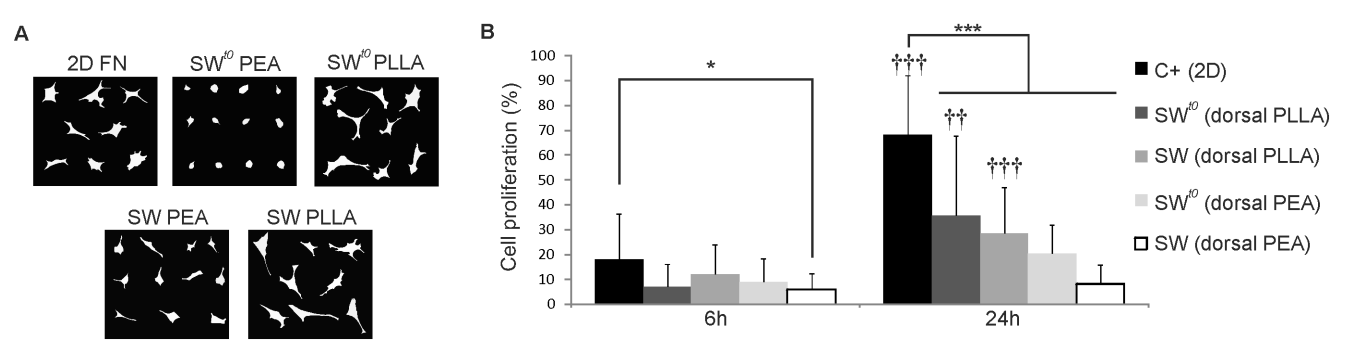

Figure 4.16. Cell morphology and proliferation comparing sandwich cultures where FN-PEA or FN-PLLA was used as dorsal substrate. $\Phi$ Stands for significant differences with time and ${ }^{*}$ differences with the control (for the same culture time).

\section{Biological stimuli vs mechanical stimuli}

To better support this hypothesis, cells seeded on standard 2D surfaces were coated with either FN or anti- $\alpha_{5}$ antibody dissolved in the culture medium so that they promote the activation of dorsal integrins without any material (physical) support. Hence this culture mimics the dorsal receptors excitation and can be considered a condition where dorsal remodelling is not constrained by any protein-material interaction. Under this culture conditions, no changes in either cell morphology or cell adhesion were observed as compared to the 2D controls (figure 4.17). Actually, spread cells with well-defined focal plaques containing vinculin were observed, revealing the distinctive mechanism of the sandwich microenvironment to trigger cell adhesion depending on the dorsal stimuli. Besides, similar level of proliferation rates were achieved for every condition (figure 4.18), supporting the importance of the biophysical cues. Dorsal stimulation (bio and mechanical inputs) is therefore a key parameter for cell behaviour and understanding its role will allow us to tune cell fate. 

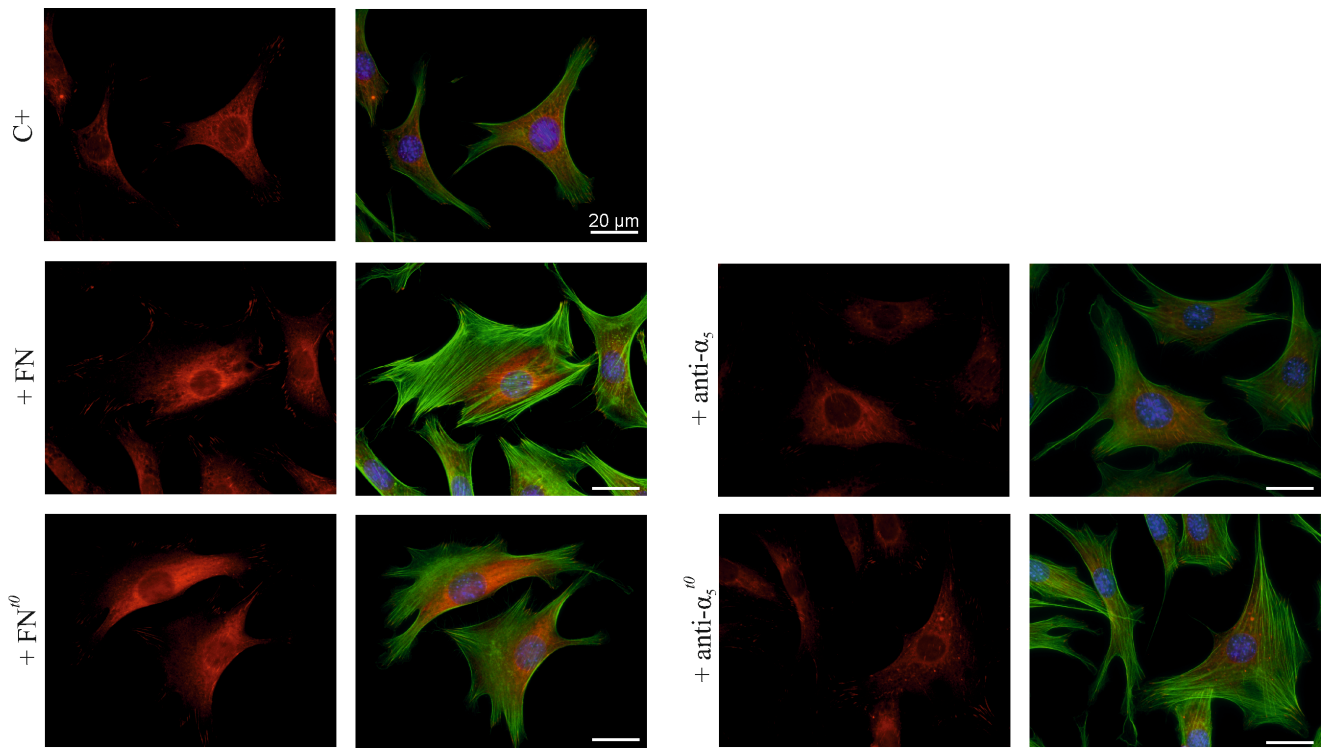

Figure 4.17. Cytoskeleton organisation and focal adhesion formation when FN (50 $\mu \mathrm{g} / \mathrm{ml})$ or anti- $\alpha_{5}$ antibody $(1.2 \mu \mathrm{g} / \mathrm{ml})$ were added to the medium immediately after cell seeding ( $\mathrm{t} 0$ ) or 3 hours later in order to activate dorsal receptors and mimic the sandwich environment. Fluorescence images show vinculin (red), F-actin cytoskeleton (green) and nuclei (blue). The total culture time was 6 h. No differences were observed after 24 hours of culture.

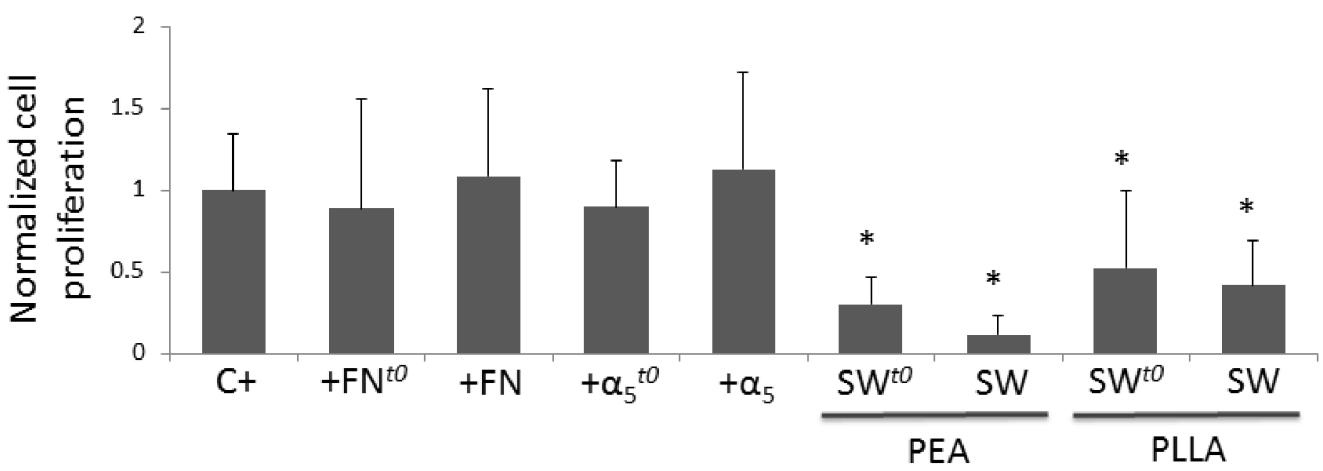

Figure 4.18. Cell proliferation after $24 \mathrm{~h}$ of culture when FN ( $50 \mu \mathrm{g} / \mathrm{ml})$ or anti- $\alpha_{5}$ antibody $(1.2 \mu \mathrm{g} / \mathrm{ml})$ were added to the medium immediately after cell seeding (t0) or 3 hours later in order to activate dorsal receptors and mimic the sandwich environment. Results for sandwiches with dorsal FN-PEA and FN-PLLA are included for the sake of clarity. Data were normalized to the 2D control. Statistical differences with respect to the control are marked with ${ }^{*} \mathrm{P}<0.05$. 


\subsection{Conclusions}

The use of sandwich-like cultures has been shown to be a robust tool to investigate the role of dimensionality in cell-materials interactions by allowing the combination of different adhesive proteins and geometrical inputs in both dorsal and ventral sides.

Overall, cell adhesion within dorsal PEA sandwiches showed enhanced $\alpha_{5} \beta_{1}$ integrin-mediated adhesion and lower activation of FAK signalling pathways as a consequence of the dorsal material stimuli. These dorsal stimuli stopped cell spreading and somehow froze cells into the attained morphology (rounded within SW $\mathrm{SW}^{t 0}$ and more spread -but not as 2D controls- within SW). This is correlated with the lack of well-developed focal adhesion plaques within sandwich-like cultures. Strikingly, cell morphology in SW environments might not be only a consequence of integrin-mediated adhesion to the surrounding matrix, as BSA-covered top-substrates elicit similar response as FN-coated one. That is to say, not only protein-protein interaction should be considered to explain cell behaviour in SW environments, but also the role of a pure mechanicalcontact interaction must be considered. Cell proliferation decreased within sandwich cultures compared to the 2D control and blocking the integrin-FN dorsal interaction (with HFN7.1 antibody) did not result in the same proliferation rate as in $2 \mathrm{D}$, which suggests again the importance of the dorsal material stimulation. In this way, cells sandwiched with PLLA where FN adopts a globular conformation and can be mechanically remodelled by cells- showed differences in cell morphology, adhesion and proliferation with respect to sandwiches with dorsal FN-PEA, suggesting the key role of protein reorganisation to tune cell fate into a closer 3D environmental manner. This was further corroborated by overlaying the cells with VN-PEA and adding FN or anti- $\alpha_{5}$ antibody to the medium. The ability to reorganise the ECM is therefore fundamental to understand cell adhesion, cytoskeleton development and cell morphology within sandwich culture, as well as in both 2D and 3D systems. ${ }^{13,44}$ Our results suggest that cells behave within sandwich culture similarly as within 3D hydrogels. Cells sandwiched with FN-PEA (where FN cannot be reorganised) adopted a rounded morphology with diffused adhesions (resembling cells in nondegradable hydrogels) while cells adopted a spread morphology with 
well-defined adhesion when sandwiched with the reorganisable FN layer on PLLA (resembling cells in MMP-sensitive hydrogels), ${ }^{28,30,45}$ These results support therefore the hypothesis that sandwich cultures can mimic 3D environments, giving rise to a wide variety of uses.

So, even if our sandwich-like system is not a truly representation of a 3D situation, it is a useful model beyond 2D systems, and it allows a controlled and versatile tunning of the substrates and composition, more difficult to tailor in standard 3D environments such as Matrigel or collagen gels.

\subsection{References}

1. Folkman J, Moscona A. Role of cell shape in growth control. Nature. 1978;273:345.

2. Watt FM, Jordan PW, O'Neill CH. Cell shape controls terminal differentiation of human epidermal keratinocytes. Proc Natl Acad Sci U S A. 1988;85:5576.

3. Weiss P. Interactions between Cells. Rev Mod Phys. 1959;31:449.

4. Lewis WH, Lewis MR. Behavior of cells in tissue cultures. In: General Cytology. The University of Chicago Press, Chicago. 1924:385

5. Weiss P. Cellular Dynamics. Rev Mod Phys. 1959;31:11.

6. Cukierman E, Pankov R, Stevens DR, Yamada KM. Taking cellmatrix adhesions to the third dimension. Science. 2001;294:1708.

7. Mao Y, Schwarzbauer JE. Stimulatory effects of a three-dimensional microenvironment on cell-mediated fibronectin fibrillogenesis. J Cell Sci. 2005;118:4427.

8. Larsen M, Artym VV, Green JA, Yamada KM. The matrix reorganized: extracellular matrix remodeling and integrin signaling. Curr Opin Cell Biol. 2006;18:463.

9. Salmerón-Sánchez M, Rico P, Moratal D, Lee TT, Schwarzbauer JE, García AJ. Role of material-driven fibronectin fibrillogenesis in cell differentiation. Biomaterials. 2011;32:2099. 
10. Rico P, Rodríguez Hernández JC, Moratal D, Altankov G, Monleón Pradas M, Salmerón-Sánchez M. Substrate-induced assembly of fibronectin into networks: influence of surface chemistry and effect on osteoblast adhesion. Tissue Eng Part A. 2009;15:3271.

11. Gugutkov D, González-García C, Rodríguez Hernández JC, Altankov G, Salmerón-Sánchez M. Biological activity of the substrate-induced fibronectin network: insight into the third dimension through electrospun fibers. Langmuir. 2009;25:10893.

12. Altankov G, Groth T. Reorganization of substratum-bound fibronectin on hydrophilic and hydrophobic materials is related to biocompatibility. J Mat Sci Mat Med. 1994;5:732.

13. Altankov G, Grinnell F, Groth T. Studies on the biocompatibility of materials: fibroblast reorganization of substratum-bound fibronectin on surfaces varying in wettability. J Biomed Mater Res. 1996;30:385.

14. Gallego Ferrer G, Monleón Pradas M, Gómez Ribelles JL, Pissis P. Swelling and thermally stimulated depolarization currents in hydrogels formed by interpenetrating polymer networks. J NonCryst Soli. 1998;235-237:692.

15. Ballester-Beltrán J, Cantini M, Lebourg M, Rico P, Moratal D, García AJ, Salmerón-Sánchez M. Effect of topological cues on materialdriven fibronectin fibrillogenesis and cell differentiation. J Mater Sci Mater Med. 2012;23:195.

16. Chaudhuri O, Parekh SH, Lam WA, Fletcher DA. Combined atomic force microscopy and side-view optical imaging for mechanical studies of cells. Nat Methods. 2009;6:383.

17. Ballester-Beltrán J, Lebourg M, Rico P, Salmerón-Sánchez M. Dorsal and ventral stimuli in cell-material interactions: effect on cell morphology. Biointerphases. 2012;7:39.

18. Altankov G, Groth T, Krasteva N, Albrecht W, Paul D. Morphological evidence for a different fibronectin receptor organization and function during fibroblast adhesion on hydrophilic and hydrophobic glass substrata. J Biomater Sci Polym Ed. 1997;8:721.

19. Curtis AS, Forrester JV. The competitive effects of serum proteins on cell adhesion. J Cell Sci. 1984;71:17. 
20. Zelzer M, Albutt D, Alexander MR, Russell NA. The Role of Albumin and Fibronectin in the Adhesion of Fibroblasts to Plasma Polymer Surfaces. Plasma Process Poly. 2012;9:149.

21. Tamada Y, Ikada Y. Effect of preadsorbed proteins on cell adhesion to polymer surfaces. J Colloid Interf Sci. 1993;155:334.

22. Kubow KE, Horwitz AR. Reducing background fluorescence reveals adhesions in 3D matrices. Nat Cell Biol. 2011;13:3; author reply 5.

23. Fraley SI, Feng Y, Wirtz D, Longmore GD. Reply: reducing background fluorescence reveals adhesions in 3D matrices. Nat. Cell Biol. 2011;13:5.

24. Ochsner M, Textor M, Vogel V, Smith ML. Dimensionality controls cytoskeleton assembly and metabolism of fibroblast cells in response to rigidity and shape. PLoS One. 2010;5:e9445.

25. Hakkinen KM, Harunaga JS, Doyle AD, Yamada KM. Direct comparisons of the morphology, migration, cell adhesions, and actin cytoskeleton of fibroblasts in four different three-dimensional extracellular matrices. Tissue Eng Part A. 2011;17:713.

26. Fraley SI, Feng Y, Krishnamurthy R, Kim DH, Celedon A, Longmore GD, Wirtz D. A distinctive role for focal adhesion proteins in threedimensional cell motility. Nat Cell Biol. 2010;12:598.

27. Welch MD, Mullins RD. Cellular control of actin nucleation. Annu Rev Cell Dev Biol. 2002;18:247.

28. Wolf K, Mazo I, Leung H, Engelke K, von Andrian UH, Deryugina EI, Strongin AY, Bröcker EB, Friedl P. Compensation mechanism in tumor cell migration: mesenchymal-amoeboid transition after blocking of pericellular proteolysis. J Cell Biol. 2003;160:267.

29. Hynes RO. Integrins: a family of cell surface receptors. Cell. 1987;48:549.

30. Huebsch N, Arany PR, Mao AS, Shvartsman D, Ali OA, Bencherif SA, Rivera-Feliciano J, Mooney DJ. Harnessing traction-mediated manipulation of the cell/matrix interface to control stem-cell fate. Nat Mater. 2010;9:518.

31. Mitra SK, Hanson DA, Schlaepfer DD. Focal adhesion kinase: in command and control of cell motility. Nat Rev Mol Cell Biol. 2005;6:56. 
32. Golubovskaya VM, Kweh FA, Cance WG. Focal adhesion kinase and cancer. Histol Histopathol. 2009;24:503.

33. Bulysheva AA, Bowlin GL, Petrova SP, Yeudall WA. Enhanced chemoresistance of squamous carcinoma cells grown in 3D cryogenic electrospun scaffolds. Biomed Mater. 2013;8:055009.

34. Schoen RC, Bentley KL, Klebe RJ. Monoclonal antibody against human fibronectin which inhibits cell attachment. Hybridoma. 1982;1:99.

35. Sottile J, Hocking DC, Langenbach KJ. Fibronectin polymerization stimulates cell growth by RGD-dependent and -independent mechanisms. J Cell Sci. 2000;113:4287.

36. Gugutkov D, Altankov G, Rodríguez Hernández JC, Monleón Pradas M, Salmerón Sánchez M. Fibronectin activity on substrates with controlled --OH density. J Biomed Mater Res A. 2010;92:322.

37. Llopis-Hernández V, Rico P, Moratal D, Altankov G, SalmerónSánchez M. Role of material-driven fibronectin fibrillogenesis in protein remodeling. Biores Open Access. 2013;2:364.

38. González-García C, Cantini M, Moratal D, Altankov G, SalmerónSánchez M. Vitronectin alters fibronectin organization at the cellmaterial interface. Colloids Surf B Biointerfaces. 2013;111C:618.

39. Underwood PA, Bennett FA. A comparison of the biological activities of the cell-adhesive proteins vitronectin and fibronectin. J Cell Sci. 1989;93:641.

40. Gugutkov D, Altankov G, Rodríguez Hernández JC, Monleón Pradas M, Salmerón Sánchez M. Fibronectin activity on substrates with controlled --OH density. J Biomed Mater Res A. 2010;92:322.

41. Ballester-Beltrán J, Moratal D, Lebourg M, Salmerón-Sánchez M. Fibronectin-matrix sandwich-like microenvironments to manipulate cell fate. Biomater Sci. 2014;2:381.

42. Kilian KA, Bugarija B, Lahn BT, Mrksich M. Geometric cues for directing the differentiation of mesenchymal stem cells. Proc Natl Acad Sci U S A. 2010;107:4872.

43. Thakar RG, Cheng Q, Patel S, Chu J, Nasir M, Liepmann D, Komvopoulos K, Li S. Cell-shape regulation of smooth muscle cell proliferation. Biophys J. 2009;96:3423. 
44. Grinnell F, Petroll WM. Cell motility and mechanics in threedimensional collagen matrices. Annu Rev Cell Dev Biol. 2010;26:335.

45. Khetan S, Guvendiren M, Legant WR, Cohen DM, Chen CS, Burdick JA. Degradation-mediated cellular traction directs stem cell fate in covalently crosslinked three-dimensional hydrogels. Nat Mater. 2013;12:458. 



\section{Chapter 5. Cell migration}

\section{Summary}

Here we have studied cell migration within sandwich culture since plays an important role in key biological processes such as cancer, wound healing, immune responses and morphogenesis. Different parameters have been investigated such as the protein coating (fibronectin, vitronectin) and/or the materials (using polymers that adsorb proteins in qualitatively different conformations) to show their specific role in cell migration. Results show that cell migration within sandwich culture greatly differs from the $2 D$ culture and shares similarities with the migration within $3 D$ environments. Moreover, beyond differences in cell morphology and migration, dorsal stimulation promotes cell remodelling of the ECM over simple ventral receptor activation in traditional $2 D$ cultures.

*Results presented in this chapter have been compiled in: BallesterBeltrán J, Lebourg M, Rico P, Salmerón-Sánchez M. Cell migration within confined sandwich-like microenvironments. Nanomedicine (submitted) 



\subsection{Introduction}

Cell migration is an essential process from embryonic development to adulthood since abnormalities cause congenital disorders, inflammation, wound healing disorders and metastasis. Hence, studying cell migration on well-defined environments is required to better understand the cellular mechanisms involved, search for novel therapeutic targets and design optimal implants. Cell migration has been extensively studied in vitro on 2D surfaces, where it is described as a lamellipodia-based process with implication of integrins and cell contractility. It consists of 4 steps: extension of the leading edge, adhesion formation, traction generation and subsequent retraction of the trailing edge. ${ }^{1}$ So, cell migration on $2 \mathrm{D}$ substrates is integrin-mediated and depends on the traction force cells can exerce on the material. Nevertheless, as seen for other processes, cell migration has been shown to differ between the traditional 2D models in vitro and in vivo situations. ${ }^{2-5}$ Concretely, when cultured within $3 \mathrm{D}$ culture systems, different types of single cell migration can be seen: (i) mesenchymal migration which is proteolytic dependent and lamellipodiabased so that concurses in a similar way to 2D migration; (ii) amoeboid migration which is non-proteolytic dependent and where adhesions are inexistent or very weak $^{6-8}$ and (iii) lobopodia-based migration that is determined by large cylindrical protrusions and depends on the 3D matrix elasticity. ${ }^{9}$ Additionally, cells of the same type can switch between different modes of cell motility in response to physical properties of the environment, integrin impairment, degradability and soluble signalling factors. ${ }^{9-12}$

Given the difficulty of mimicking the in vivo ECM environment, different complex 3D culture systems have been used to study cell migration. ${ }^{11}$, 13-15 Unfortunately, differences inter- and even intra- 3D systems as well as difficulties in having reliable 2D controls hinder identifying and understanding the key features in 3D cell migration. Moreover, there is still lack of proper quantitative methods for analysis of migration rates in 3D environments. New procedures to better understand cell migration within 3D cultures are therefore needed. 
We have shown in the previous chapter that sandwich-like microenvironments provide dorsal stimulation similar to 3D systems and trigger cell signalling pathways that promote more similar cell behaviour to 3D environments. Hence, we hypothesise that the excitation of dorsal receptors by sandwich culture might lead cell migration towards 3D modes. We have studied the effect of different parameters such as the cell seeding procedure (culturing either isolated cells or as in wound healing assays), the chemistry of the ventral surface (using poly(ethyl acrylate), poly(methyl acrylate) and glass) and the biological input coming from the dorsal substrate (coating samples with different proteins, e.g. fibronectin (FN) and vitronectin (VN)). Poly(lactic acid) (PLLA) was used as dorsal substrate in all cases. Cell morphology, adhesion and migration under different culture conditions were characterised; as well as the influence of the dorsal stimulation on the ability of cells to remodel the ECM.

\subsection{Materials and methods}

\subsubsection{Materials}

Different combinations of materials and proteins were used in this work (figure 5.1). Fibronectin adsorption on the different materials was determined by AFM in terms of distribution and strength of interaction. Materials production and characterisation are further detailed in chapter 3.

A
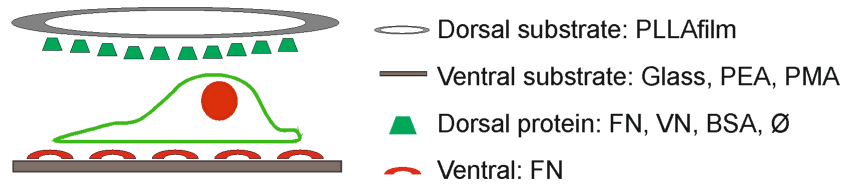

B
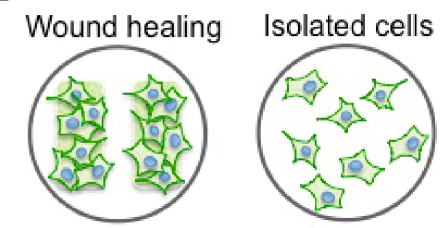

Figure 5.1. Summary of the different conditions used in the sandwich-like cultures. (A) Sketch of the sandwich-like model and the different combinations of material and proteins. (B) Sketch of the two different cell cultures used during this work: wound healing assay and isolated cells. 


\subsubsection{Cell culture}

L929 fibroblasts were maintained in Dulbecco's Modified Eagle Medium (DMEM) supplemented with $10 \%$ fetal bovine serum and $1 \%$ penicillinstreptomycin (Lonza) prior to their seeding.

For wound healing-like assays, the protein coating of the ventral samples were washed in MilliQ water to avoid salts deposition and then were air dried for 10 minutes in order to place the culture-inserts (Ibidi; figure 5.2). Then L929 cells in DMEM without serum were seeded at 30,000 cells/insert-well to obtain confluent layers. After $3 \mathrm{~h}$ of culture, inserts were removed and non-attached cells were removed by washing twice in DPBS. Sandwich cultures were then established by gently laying the upper substrates over the seeded bottom ones.
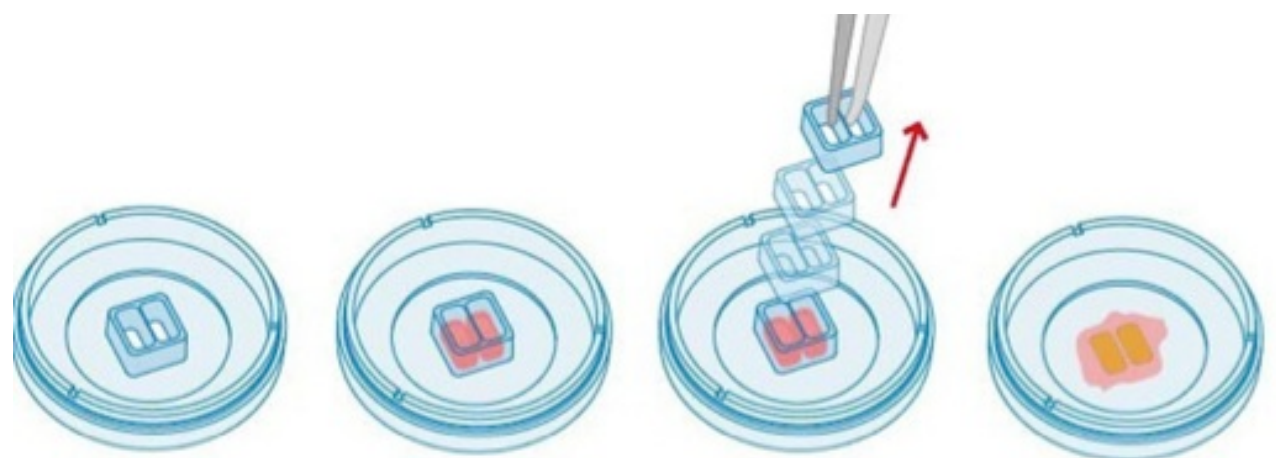

Figure 5.2. Handling of Ibidi culture-inserts. Due to the adhesive design, cultureinsert sticks itself on the cell culture surface providing two cell culture reservoirs which are separated by a $500 \mu \mathrm{m}$ thick wall.

For isolated cells, L929 cells were seeded at 5,000 cells $/ \mathrm{cm}^{2}$ in serum-free DMEM in order to induce specific fibronectin-cell adhesion. After $3 \mathrm{~h}$ of culture, once cells were adhered and spread, sandwich cultures were obtained by laying the upper substrates over the bottom seeded ones.

Medium supplemeted with 2\% FBS (instead of the growth medium) was used during the migration experiments in order to avoid FBS-induced cell proliferation and to ease comparisons since medium diffusion within sandwich culture might be hindered when compared with 
2D samples. Besides, medium was supplemented with 1\% Hepes (Sigma) to prevent changes in $\mathrm{pH}$. However, for fibronectin reorganisation experiments, the culture was kept in medium without serum (unless otherwise noted) in order to avoid the reorganisation induced by the FBS. When used, contractility inhibitors were added to culture medium (10 $\mu \mathrm{M}$ ) after 2 hours of cell seeding and maintained until the end of the culture.

\subsubsection{Biological characterisation}

Time-lapse cell imaging along $24 \mathrm{~h}$ of culture allowed the study of cell migration and gap closure measurements. Additionaly, the morphology and distribution of focal adhesions were analyzed by The Focal Adhesion Analysis Server. ${ }^{16}$ Protocols are explained in more detail in chapter 3.

\subsection{Results and discussion}

\subsubsection{Phenomenology of cell migration within sandwich environments}

We have studied L929 fibroblasts migration within sandwich cultures using a modified wound healing assay based on culture inserts since manual scratching strips off the thin spin-coated polymer films. Moreover manual scratching of cell monolayers has been correlated to changes in cell morphology, alteration of proliferation and deregulation of migration. ${ }^{17}$ For this first study we have used glass coverlisps as ventral substrates and PLLA films as dorsal ones, both coated with fibronectin (FN) - an important adhesion protein relevant to wound healing -. Notwithstanding, a variety of protein coatings and materials are studied during this work in order to assess their specific role on cell migration (figure 5.1).

Movie 5.1 (supplementary material) shows cell migration on FN coated glass coverslips (2D) and then after overlying with a FN-coated PLLA film (sandwich culture, SW). Cells on the 2D control migrate according to the classical 4 migration steps, by adopting a polygonal shape with wide lamellipodia and pseudopodia projections. ${ }^{18,19}$ However, cells within sandwich culture adopted an elongated morphology with fewer 
pseudopodia (usually 1 or 2 ) but longer and more persistent in time resembling what has been observed in other $3 \mathrm{D}$ environments (figure 5.3A). ${ }^{9}, 20,21$ Such elongated cell morphology for migrating cells has not been previously observed within our sandwich microenvironments (chapter 4).22-24 Importantly, note also that cells migrating in sandwich environments hardly move their nuclei from the initial position, which suggests that the last steps of the migration process (traction generation and the retraction of the trailing edge) were hindered or not coordinated. ${ }^{25}$

The characteristic elongated morphology of cells migrating within the sandwich during the wound healing assay was not previously observed by us. ${ }^{23}, 24$ One might think that the elongated morphology observed at the front edge of the 2 cell populations in a wound healing assay might be related to the biochemical signal between the 2 populations (chemotaxis due to increased concetration of cell secreted signals within the SW environment), which may enhance extension directionality and persistence. However these elongated cells were observed along the whole border of the seeded fields, not only the ones facing the wound. So we first assesed whether this elongated morphology was due to the high cell density used during the wound healing-like assay rather than to the specific sandwich condition. Hence, isolated cells were cultured at low density and migration was monitored. Figure 5.3 depicts the morphology of selected cells after different time-points of culture so cell morphology and migration can be evaluated. Cells overlaid with the FN-coated dorsal substrate (sandwich culture, referred to as $\mathrm{SW}^{\mathrm{FN}}$ ) did not show such elongated morphology. Hence the cause of this elongated morphology should be sought as a consequence of dorsal stimuli and high cell density population which suggest the important role of cell-cell contact and Rac1 signalling. ${ }^{26}$ To corroborate this, high cell density areas of the wound healing were imaged and it was seen that only cells in the perifery of the population projected the long pseudopodia whilst cells inside the population remained with a polygonal shape since there was no space to project the pseudopodia (data not shown). 
When the morphology of migrating cells within the sandwich culture was studied more in depth (figure 5.3) we saw that the circularity of isolated cells was similar to the circularity of cells during the wound healing assay (figure 5.3B) and, most importlantly, isolated cells within sandwich culture showed different roundness than isolated cells cultured on 2D substrates. These suggest that, despite not having such long pseudopodia, cells sense the dorsal stimuli and respond to it by changing their morphology as reported for other 3D systems. ${ }^{27,} 28$ Moreover, we have recently shown that cell morphology within sandwich culture highly depends on the substrate properties similarly as happens in 3D cultures (chapter 4). ${ }^{24}$ Regarding cell motility, cells cultured on 2D substrates moved around the starting point in random open trajectories, whereas cells within $\mathrm{SW}^{\mathrm{FN}}$ remained mainly static at the initial location, and only cytoplasmatic extensions were projected (figure 5.3C). So, sandwich culture hinders cell migration and nuclei movement both for isolated and wound healing cultures though cells do project long pseudopodia only in the latter case.

In order to investigate the role of the nature of the dorsal stimulus, cells were studied also when sandwiched with an un-coated dorsal substrate $\left(S W^{\varnothing}\right)$. As a consequence these cells received similar biological signals than cells on 2D samples, as the only biologically driven interaction comes from the ventral substrate. As shown in figure 5.3C, cells within SWø can move and change their location, though less than on 2D substrates, and tend to remain attached to the initial position by long pseudopodia connecting this specific point with the cell body. Thus, similarly as seen for the wound healing assay, sandwich culture seems to hinder focal adhesion release and retraction of the trailing edge. The lack of protein coating on the dorsal substrate is therefore related to an increased cell migration compared to $\mathrm{SW}^{\mathrm{FN}}$, though cells do not behave as on the 2D control. This suggests that not only the biological but also the mechanical stimuli are important cues in sandwich environments. 
A
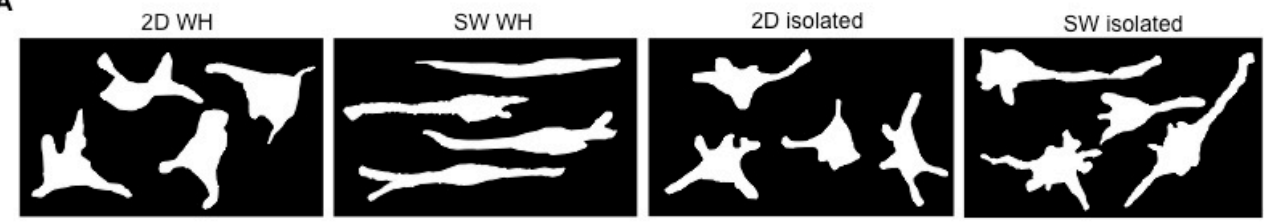

B

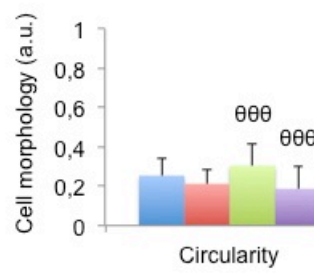

C

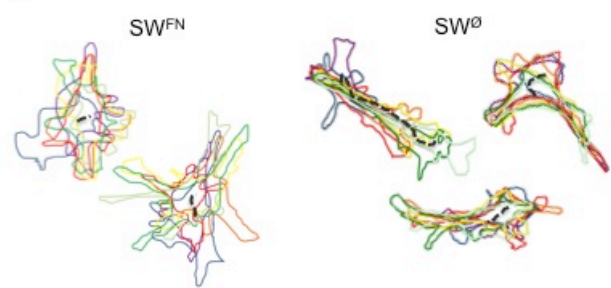

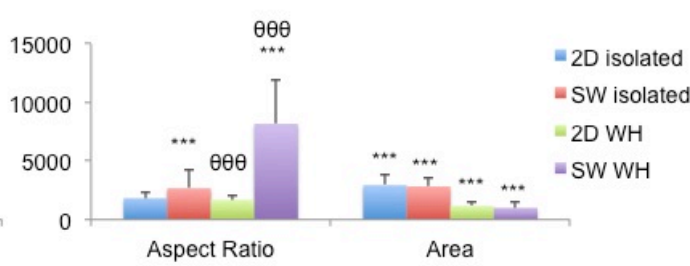

$2 \mathrm{D}$

Figure 5.3. Cell migration and morphology when FN-glass was used as the ventral substrate and FN-PLLA as the dorsal one. (A) Cell morphology after 12 hours of migration in a wound healing assay ( $\mathrm{WH})$ or as isolated cells (isolated). (B) Morphology of cells after 12 hours of culture under different culture conditions. Statistically significant differences are indicated with ${ }^{*} \mathrm{P}<0.05$ and ${ }^{* * *} \mathrm{P}<0.001$, where * shows significance comparing isolated with wound healing for the same type of dimensionality (2D or SW); and $\theta$ comparing 2D with SW for the same type of culture condition (isolated or wound healing). (C) Outlined cells after different time points of culture (shown by different colours). Dotted lines represent cell nuclei movement. Coordinates are mantained for each outlined cell so that the displacement displayed in the picture is equivalent to the migration oberved during the culture.

\subsubsection{Characterisation of the migrating cells}

Cells migrating in the wound healing assay were further characterised seeking to understand differences with 2D conditions. Cultures were kept for $7 \mathrm{~h}$ to allow cells to project these characteristic long pseudopodia within the sandwich culture. First, focal adhesion proteins and integrins were evaluated as it is well accepted that these differ between $2 \mathrm{D}$ and $3 \mathrm{D} /$ in vivo environments ${ }^{2,28-30}$ and so it might have an influence on cell 
migration as well. Focal adhesion proteins such as pFAK ${ }^{\text {Tyr925 }}$ and vinculin were detected at the cell edge when cultured on 2D substrates (figure 5.4). Within sandwich microenvironments, these proteins were localised mainly at the rear part of the cell but also at the tip of the long pseudopodia. Besides, colocalisation between vinculin and pFAK $^{\text {Tyr925 }}$ was observed in both conditions. Further differences between vinculin and pFAK were not only observed between 2D and SW cultures but also when comparing the leading and rear part of cells migrating within the sandwich culture (table 5.1 and 5.2). As summarised in table 5.1, cells within the sandwich culture have more focal adhesions at the rear part than at the leading. This might explain why cells cannot retract the trailing edge during migration and only long pseudopodia can be projected. Likewise, the bigger focal adhesions seen for the sandwich culture (as well as the regulation of their turnover) might explain the lower migration rate in a similar way as has been shown for 2D substrates. ${ }^{25,31}$

Table 5.1. pFAK and vinculin characterisation in the leading and rear part of cells migrating within sandwich culture in a wound healing assay. Cells were manually split in two: pseudopodial projection and rear cell body. Statistical differences are marked out with *.

Leading

Rear

$P$ value

\begin{tabular}{|c|c|c|c|}
\hline \multicolumn{4}{|l|}{ pFAK } \\
\hline \# Focal adhesions & $165,11 \pm 67,33$ & $263 \pm 90,8$ & $<0.0001^{*}$ \\
\hline Area $\left(\mu m^{2}\right)$ & $1,06 \pm 0,23$ & $0,81 \pm 0,18$ & $<0.0001 *$ \\
\hline Total Area $\left(\mu m^{2}\right)$ & $164,47 \pm 41,92$ & $205,80 \pm 58,07$ & $0.0065 *$ \\
\hline Distance to edge $(\mu \mathrm{m})$ & $1,83 \pm 0,52$ & $4,49 \pm 1,01$ & $<0.001 *$ \\
\hline Major axis $(\mu m)$ & $1,46 \pm 0,2$ & $1,29 \pm 0,15$ & $0.0019 *$ \\
\hline Minor axis $(\mu m)$ & $0,79 \pm 0,09$ & $0,68 \pm 0,06$ & $<0.0001 *$ \\
\hline \multicolumn{4}{|l|}{ Vinculin } \\
\hline \# Focal adhesions & $163,27 \pm 68,83$ & $279,56 \pm 106,6$ & $0.0012 *$ \\
\hline Area $\left(\mu m^{2}\right)$ & $0,84 \pm 0,31$ & $0,88 \pm 0,25$ & 0.68 \\
\hline Total Area $\left(\mu m^{2}\right)$ & $133,56 \pm 65,62$ & $234,45 \pm 71,45$ & $0.0003 *$ \\
\hline Major axis $(\mu m)$ & $1,36 \pm 0,28$ & $1,41 \pm 0,21$ & 0.54 \\
\hline Minor axis $(\mu m)$ & $0,67 \pm 0,11$ & $0,71 \pm 0,10$ & 0.30 \\
\hline
\end{tabular}


Table 5.2. pFAK and vinculin adhesions in 2D and sandwich cultures. Statistical differences are marked out with *.

2D SW P value

\begin{tabular}{|c|c|c|c|}
\hline \multicolumn{4}{|l|}{ pFAK } \\
\hline \# Focal adhesions & $682,22 \pm 193,64$ & $382,75 \pm 98,31$ & $0.0014^{*}$ \\
\hline Area $\left(\mu m^{2}\right)$ & $0,57 \pm 0,05$ & $0,69 \pm 0,14$ & $0.0014 *$ \\
\hline Total Area $\left(\mu m^{2}\right)$ & $387,31 \pm 100,69$ & $258,33 \pm 64,95$ & $0.0046^{*}$ \\
\hline Distance to edge $(\mu m)$ & $6,39 \pm 1,56$ & $3,56 \pm 0,89$ & $0.0003 *$ \\
\hline Major axis $(\mu m)$ & $1,03 \pm 0,03$ & $1,20 \pm 0,14$ & $<0.0001 *$ \\
\hline Minor axis $(\mu m)$ & $0,61 \pm 0,02$ & $0,65 \pm 0,06$ & $0.0154^{*}$ \\
\hline \multicolumn{4}{|l|}{ Vinculin } \\
\hline \# Focal adhesions & $495.44 \pm 185.9$ & $278 \pm 114.29$ & $0.0197^{*}$ \\
\hline Area $\left(\mu m^{2}\right)$ & $0,74 \pm 0,10$ & $0,66 \pm 0,09$ & 0.59 \\
\hline Total Area $\left(\mu m^{2}\right)$ & $357,04 \pm 102,95$ & $240,05 \pm 50,17$ & $0.0108^{*}$ \\
\hline Major axis $(\mu m)$ & $1,30 \pm 0,11$ & $1,33 \pm 0,17$ & 0.27 \\
\hline Minor axis $(\mu m)$ & $0,61 \pm 0,03$ & $0,64 \pm 0,38$ & 0.07 \\
\hline
\end{tabular}

Actin cytoskeleton and $\alpha$-tubulin expression were also studied to correlate with the cell morphology observed for each condition. Stressed actin fibers and developed $\alpha$-tubulin microtubules were seen in both cases with the only difference of cell morphology. Due to the elongated cell morphology within the sandwich culture, cell nuclei within SW cultures were confined in a narrower space. Likewise, a broad actin lamellipodia was seen for cells seeded on 2D substrates but not for cells seeded within the sandwich culture (figure 5.4). Similar elongated fibroblast morphology has been previously described for other 3D systems. Concretely, elongated cells having multiple long protrusions with small lamellipodia at their tips and enriched with Rac1, cortactin, PIP3 and Cdc42 have been shown to use lamellipodia-based migration whereas elongated cells with fewer protrusions lacking lamellipodia use the lobopodia-based migration. Interestingly, cells can switch between these 2 migration modes according to the elastic properties of the 3D environment, which involve RhoAROCK-myosin II signalling. ${ }^{9}$ Here we can see elongated cells with less lamellipodia than cells on 2D samples and without lateral blebs, which correspond to cells migrating in a lamellipodia-based mode. However, cells only have 1 or 2 protrusions at the leading edge suggesting an intermediary state in between lamellipodia and lobopodia-based 
migration, likely to be a consequence of the environment provided by the sandwich system (figure 5.3A). In this way, as hypothesised, modifying the sandwich conditions should lead to different cell behaviour such as different ways of migration. ${ }^{27}$

ECM degradation is another key step for cell migration throughout 3D substrates since cells can use different modes of migration depending on the degradability of the substrates (i.e. degradable $v$ non-degradable hydrogels) and the properties of the ECM (such as the pore size). ${ }^{11,32}$ In our model, due to the nature of the system, the porosity of the ECM should not hinder migration within sandwich cultures since cells are confined between two 2D substrates and cannot migrate in the $\mathrm{z}$ axis. However, ECM remodelling and degradation in order to facilitate cell movement might be altered. So we studied the matrix metalloproteinases (MMPs) the main enzymes secreted by cells to degrade the ECM - by immunodetecting MMP2 and MMP13, two of the MMPs that degrade FN. ${ }^{33}$, ${ }^{34}$ As can be seen in figure 5.4, MMP2 and MMP13 were similarly detected throughout the entire cell body both on 2D and SW cultures suggesting no differences in their expression. 

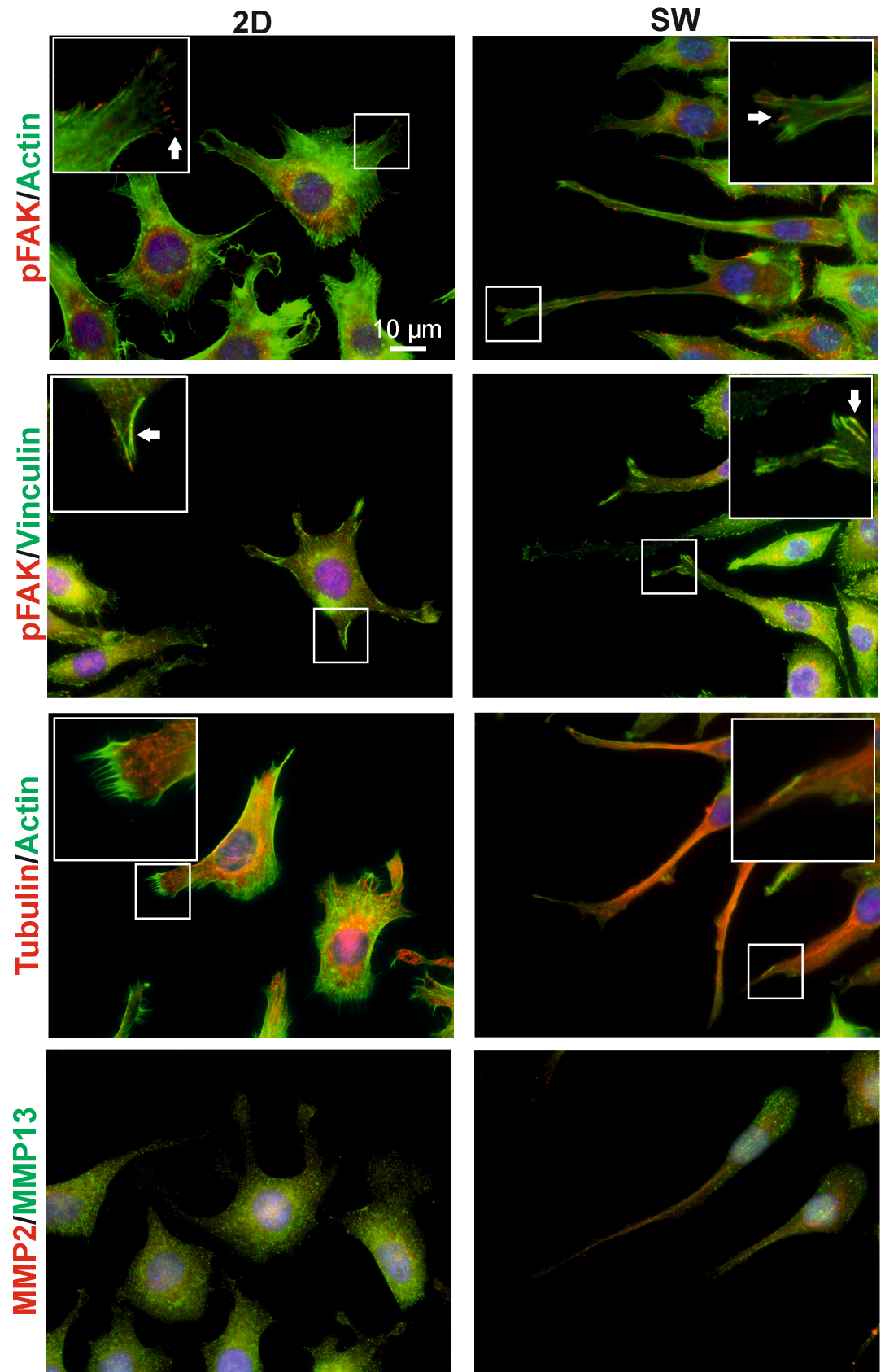

Figure 5.4. Immunodetection of focal adhesion proteins and actin cytoskeleton in cells cultured on 2D and SW conditions after 7 hours of culture. Insets show magnifications of the focal adhesions and cell cytoskeleton and arrows point out focal adhesions localisation. 


\subsubsection{Ventral ECM remodelling during cell migration}

It has been found that fibroblasts migrating in the lamellipodia-based mode remodel their matrix whereas they don't in the lobopodia mode. ${ }^{9}$ This led us to consider the role of SW environments in ECM remodelling. Hence, the fate of ventral FN was studied on FN-coated glass (2D) and when overlaid with a dorsal FN-coated PLLA film (SW). As a positive control cells were cultured with growth medium (10\% FBS) as this naturally trigger ECM reorganisation. ${ }^{35} \mathrm{It}$ is important to remark here that for the rest of conditions cells were cultured in serum-free medium, so that only the influence of the sandwich environment was considered. Figure 5.5 shows that, regardless the migration model used (wound healing or isolated cells), FN was not remodelled on 2D substrates whilst cells formed new FN fibrils within sandwich cultures. Dorsal stimuli do therefore triggered this ECM remodelling, as reported for FN and collagen in 3D matrices. ${ }^{9}, 36 \mathrm{FN}$ fibrils were formed at the tips of the cellular protrusions in close proximity to focal adhesions, suggesting a cell adhesion dependent process. In order to better characterise this process, we cultured cells within the SW under different dorsal conditions by coating with different proteins (vitronectin, bovine serum albumin or uncoated; SWVN, SWBSA and SWø respectively). As controls we used 2D samples where the corresponding dorsal protein was in the culture medium, so that dorsal receptors would be biologically but not mechanically stimulated. As summarised in table 5.3, FN reorganisation only occurred in sandwich cultures regardless of the protein coating used, even ocurring when the dorsal PLLA was coated with BSA - SWBSA (a nonadhesive protein) - or left uncoated $\left(S W^{\varnothing}\right)$. Hence the mechanical dorsal input has a key role to trigger FN reorganisation and determine cell fate (figure 5.5 and table 5.3). This result is in line with the effect that a 3D microenvironment has on promoting fibronectin assembly. ${ }^{36}$ 

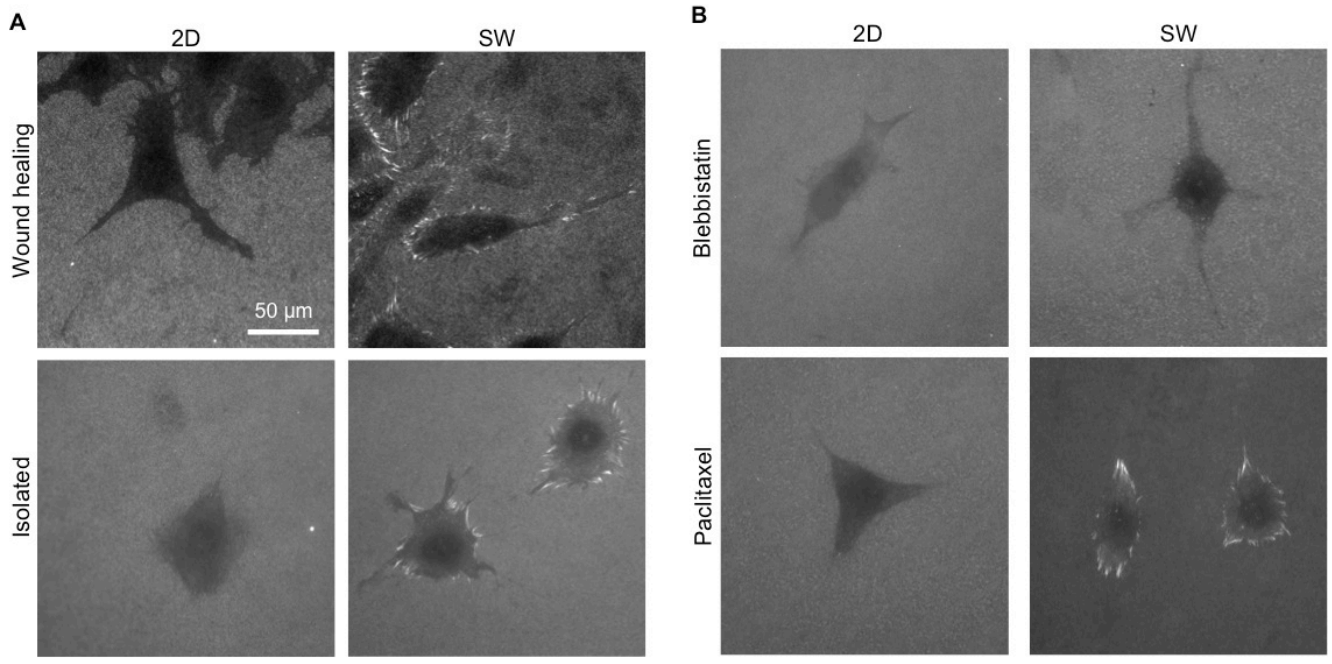

Figure 5.5. Ventral FN reorganisation. (A) Sandwich culture triggers ventral FN reorganisation by forming new fibrils both in isolated and wound healing cultures. (B) Cytoskeleton stability is needed to reorganise FN within the sandwich culture.

Cell contractility is known to influence cell migration ${ }^{9}, 37,38$ via phosphorylation of myosin light chain (MLC) so we examine whether this may also relate to the ECM reorganisation process. To do so cells were cultured in the presence of pharmacological inhibitors that impair contractility such as the Rho/ROCK pathway inhibitor Y-27632 and Blebbistatin, a specific inhibitor of myosin II activity. In addition, cells were also cultured in the presence of Paclitaxel that stabilizes microtubules and thus has an opposite effect. Contractility inhibitors (Y27632 and Blebbistatin) impaired the ventral FN reorganisation within sandwich culture whilst Paclitaxel enhanced the reorganisation (figure 5.5B and table 5.3). Cytoskeleton stability is therefore needed to reorganise FN within the sandwich culture. Sandwich culture might trigger therefore an increase in cell contractility to make possible the reorganisation of the ventral FN. 
Table 5.3. Summary of the ventral FN reorganisation. Unless otherwise stated, FN coated glass was used as ventral substrate and a FN coated film of PLLA as dorsal substrate. + stands for reorganisation, - for no reorganisation and * marks the halo seen on PEA and commented in the next section.

\begin{tabular}{l|c|c|}
\hline & 2D & SW \\
\hline Growth medium (+C) & + & + \\
Medium w/o serum & - & + \\
Blebbistatin/Y-27632 & - & - \\
Paclitaxel & - & + \\
SWFN/VN/BSA/ø & & + \\
FN/VN/BSA dissolved in medium & - & \\
Ventral PEA/PMA & $-*$ & -
\end{tabular}

\subsubsection{Role of the ventral substrate in cell migration}

We have previously shown the importance of both ventral and dorsal stimuli on cell fate such as cell morphology and signalling (chapter 4).22, 24 We want to address now if the elongated morphology and migration rates found for migrating cells within SW environments might be tuned by using different materials as ventral substrates. To do so we used: (i) FN-coated glass, where FN adsorbs loosely in a globular conformation that can be easily reorganised by cells, ${ }^{39}$ (ii) spin-coated poly(ethyl acrylate) (PEA) on which FN assembles spontaneously into fibrillar (nano)networks ${ }^{40,41}$ and (iii) spin-coated poly(methyl acrylate) (PMA) on which FN adopts a globular conformation (figure 5.6).42 Figure 5.6A shows the cellular reorganisation of adsorbed FN after $5 \mathrm{~h}$ of culture (in growth media) on the different 2D substrates. As expected, new fibronectin fibrils were only formed on glass and PLLA (white arrows) as cells cannot reorganise FN on PEA nor PMA due to the high strength of the protein-material interactions. ${ }^{43}$ This increased protein-material interaction was further analysed by force spectroscopy measurements. Si-nitride tips were functionalised with FN and then the different materials were tested. Figure 5.6B shows representative adhesion curves for every material. 
Adhesion force (area of the peak in grey) and work (depth) were statisticaly higher for PMA and PEA (figure 5.6C). Likewise, rupture lenght (width) was higher for these polymers than for glass suggesting FN stretches when removed from the polymeric surfaces due to the higher interaction with PMA and PEA. Additionally we addressed whether the ECM reorganisation triggered by the dorsal stimuli in SW cultures was also observed on PEA and PMA in the absence of serum. Cells did not reorganise ventral FN in any case, which suggests that the dorsal stimulus is not strong enough to overcome the protein-material interaction (table 5.3). Besides, FN immunodetection showed a halo around cells when cultured on 2D PEA substrates. This has been further analised (manuscript in preparation). 

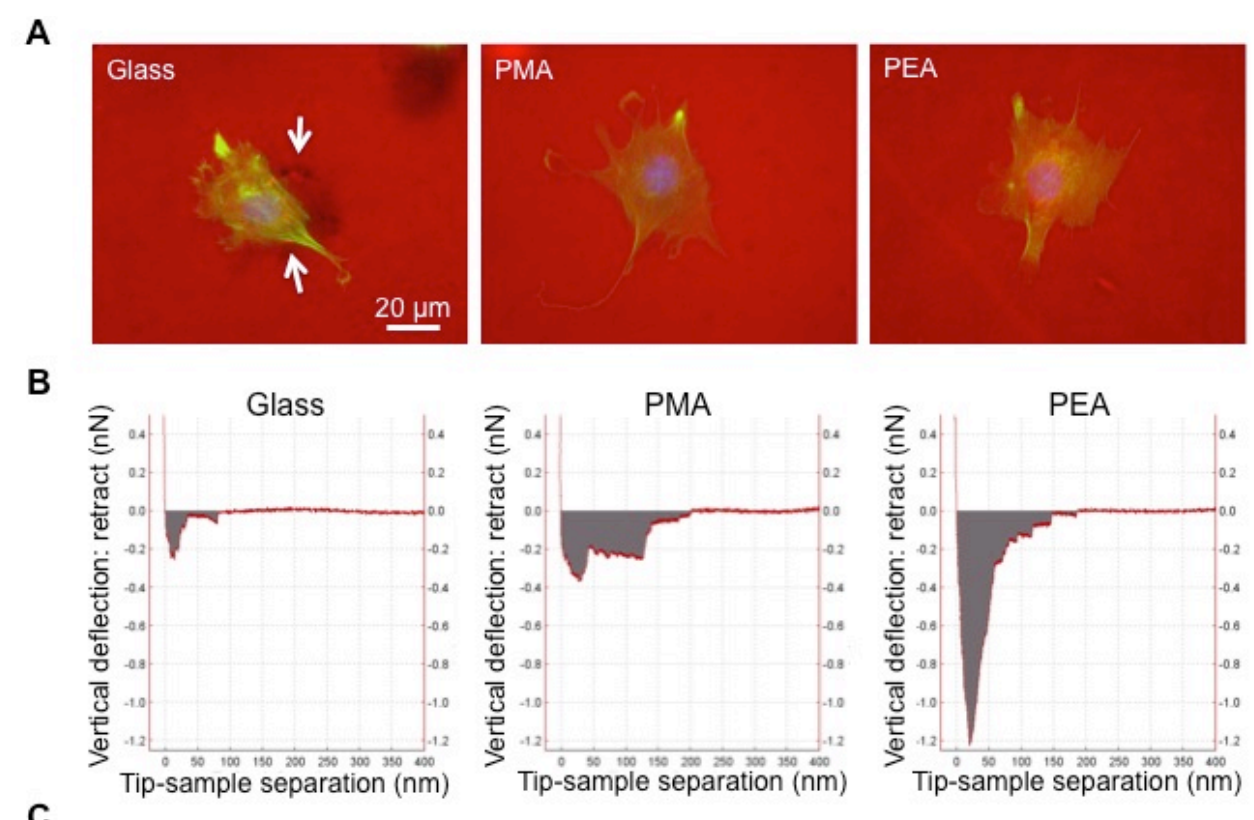

C
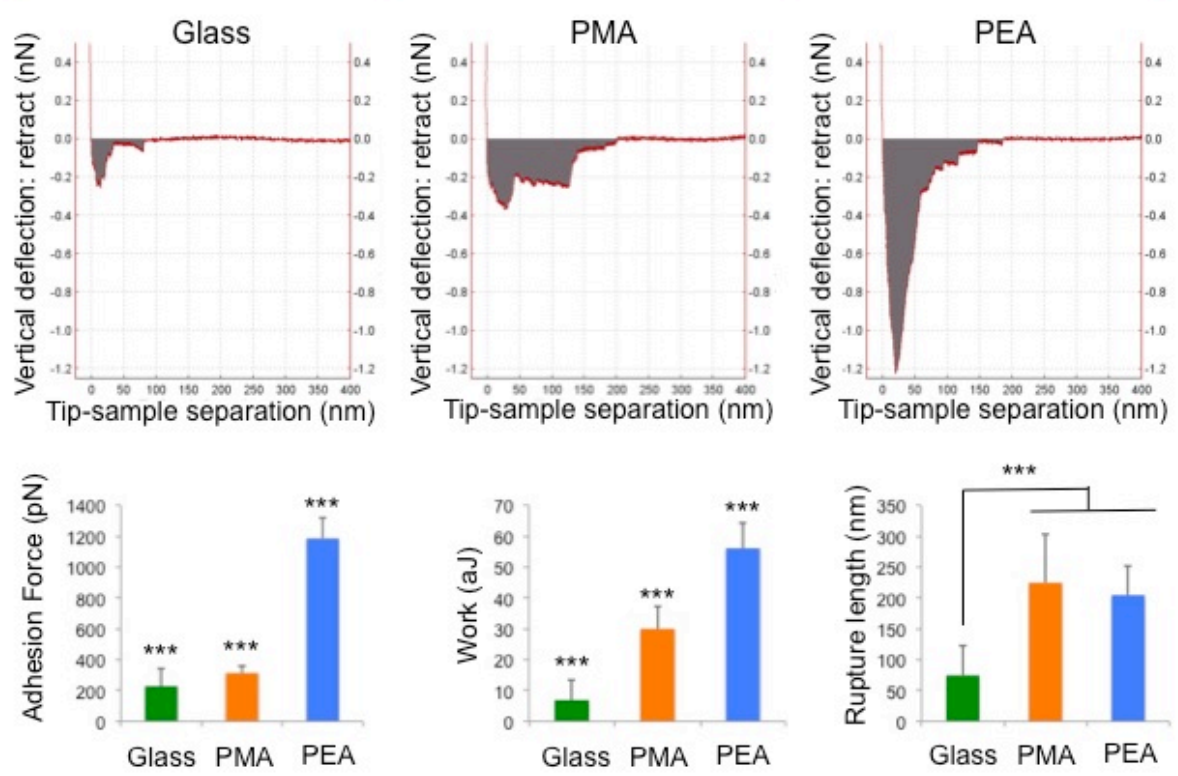

Figure 5.6. Fibronectin-material interaction with the different surfaces. (A) Fibronectin (red) is reorganised on 2D glass but not on PEA and PMA. Actin cytoskeleton is shown in green and nuclei in blue. White arrows show the formation of newly cell-reorganised fibronectin fibrils. (B) Representative adhesion curves for the different materials. (C) Adhesion force, work and rupture lenght for every condition. Statistical differences are marked with ${ }^{* * *} \mathrm{P}<0.001$.

After assesing that removal of the culture insert did not alter the characteristic fibronectin adsorption and distribution on PEA and PMA (network and globular-like conformation respectively; figure 5.7B), cell migration in the wound healing assay was followed on the different materials. Gap closure, defined as the percentage of the initially void surface that is colonized by cells, is shown in figure 5.7D. Polygonal cells were observed on every 2D substrate whilst cells adopted the elongated morphology when cultured under sandwich conditions suggesting that cell morphology does not depend on the material used to assemble the 
SW. On the other hand, differences in cell migration were clearly observed between 2D and SW cultures for the same ventral substrate. Cells migrate longer distances on 2D substrates than within the SW environment, which increased gap closure. Finally, no differences in gap closure were oberved for 2D samples but, strikingly, significant differences were observed for the different SW cultures. Concretely higher gap closure occurred for cells within the sandwich with ventral PMA than for sandwiches with ventral glass or PEA - though differing to PMA only in one single carbon in the side chain - (figure 5.7C), which suggests that the conformation and the strength of FN on the material surface (globular on PMA and fibrillar structures on PEA) plays an important role in cell migration. Note that this difference is only observed for the SW culture but not for the 2D control, which stresses the role of dimensionality in cell migration.

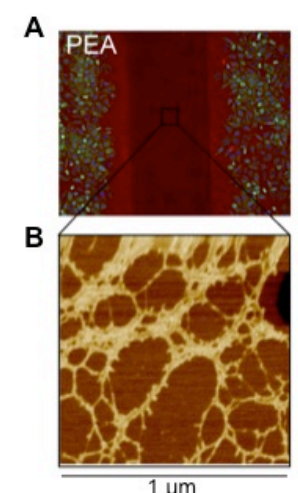

$1 \mu \mathrm{m}$
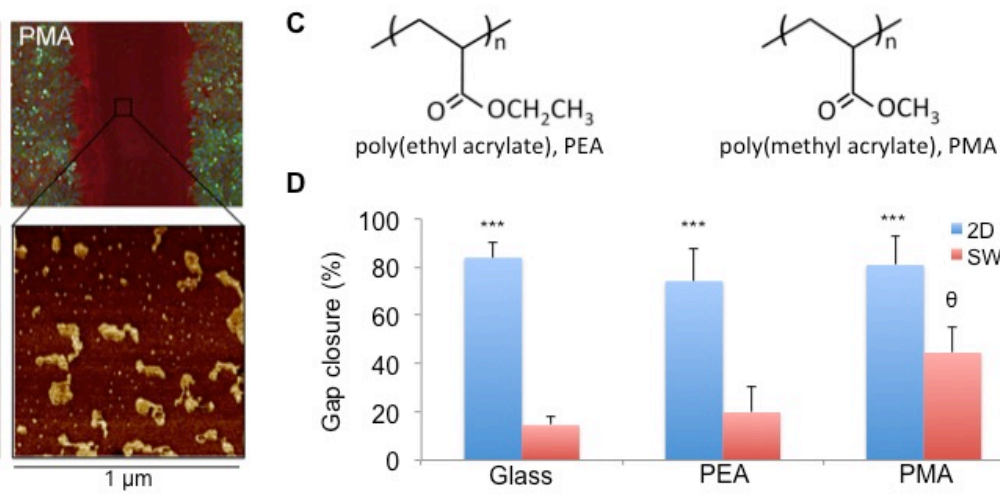

D

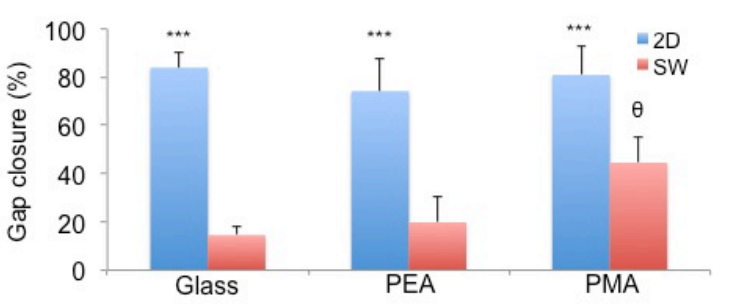

Figure 5.7. Cell migration using different ventral FN-coated surfaces. (A) Fluorescence images show the FN-coated gap $(500 \mu \mathrm{m})$ between the 2 cell populations. Actin cytoskeleton (green), nuclei (blue) and fibronectin (red) are shown. (B) AFM images of FN after insert dettachment to confirm that FN distribution is not altered and remains available on the migrating area. (C) Molecular structure of PEA and PMA. (D) Wound healing assay on 2D and SW cultures using glass, PEA and PMA as ventral substrates. Statistical differences are marked with ${ }^{*} \mathrm{P}<0.05$ and ${ }^{* * *} \mathrm{P}<0.001$, where ${ }^{*}$ shows significance comparing conditions with similar ventral substrate; and $\theta$ when comparing results of the same dimensionality (2D or SW). 


\subsubsection{Role of dorsal stimuli in cell migration}

We next examine the role of dorsal stimuli in cell migration. To do so we used FN coated glass as ventral substrate and PLLA coated with different proteins (FN, vitronectin (VN) and bare surfaces $(\varnothing)$ ) as the dorsal one. Hence, the influence of the biological dorsal stimulus could be studied (i) in terms of dorsal integrin interaction (since $\mathrm{FN}$ and VN may lead to different cell adhesion and thus different outside-in signalling) and (ii) in terms of pure mechanical stimuli (since $S W^{ø}$ might not induce any dorsal biological interaction but a response due to the bare surface).

Similarly as seen before, cells adopted polygonal morphology on 2D substrates whilst elongated within sandwiched cultures. Differences in either gap closure or cell morphology were not observed regardless of dorsal FN or VN coating. Strikingly, when overlaid by a non-adhesive dorsal substrate $\left(S W^{\emptyset}\right)$, cells maintained the characteristic elongated morphology found in SW cultures but migrated more effectively (figure 5.8 and movie 5.2). So, even when the SW does not provide additional biological input compared to $2 \mathrm{D}$ substrates - since there is only integrinFN interactions on ventral glass - cell behaviour greatly differed. This observation, together with the results showed in figure 5.3 and chapter $4,{ }^{22}$ suggests an important role for the dorsal mechanical input in cell behaviour. Hence we hypothesise that the fact that cell migration is increased under this condition (SWø; both when isolated or in wound healing assay) might be related to the fact that cells within SWFN and SWVN interact with and respond to an extra (dorsal) layer of proteins. This may delay cell migration due to the need to regulate focal adhesion formation and turnover on both dorsal and ventral substrates. 
A

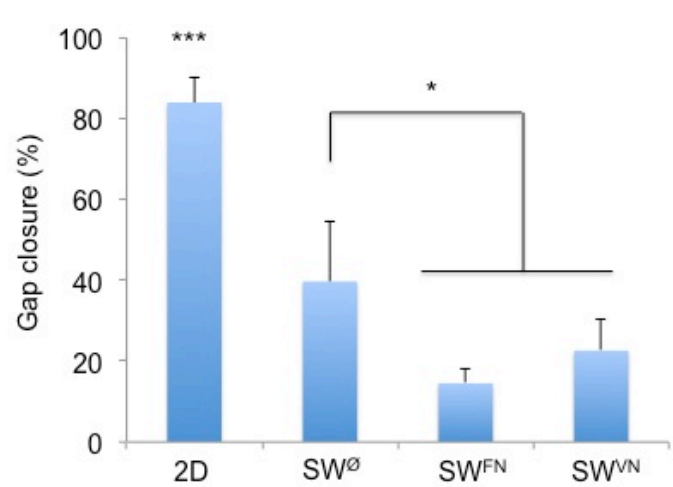

B
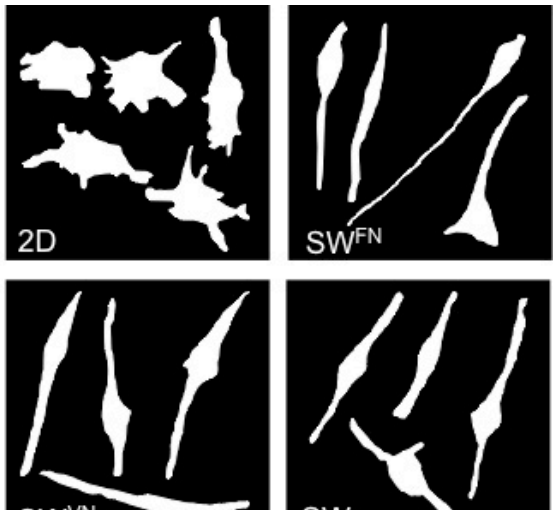

SWVN

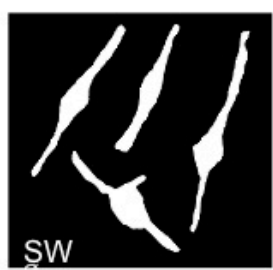

Figure 5.8. Wound healing assay on the 2D and SW cultures when FN-coated glass was used as ventral substrate whereas as dorsal substrate it was used a film of PLLA without coating (SWø) or coated with either fibronectin or vitronectin (SWFN and SWVN respetively). (B) Morphology of migrating cells after 12 hours of culture under different culture conditions. Statistical differences are marked with $* \mathrm{P}<0.05$ and ${ }^{* * *} \mathrm{P}<0.001$.

\subsection{Conclusions}

We have shown sandwich culture as a tool to investigate cell migration in a closer 3D environment than the traditional 2D substrates. The versatility of this system allows the study of cell fate under a wide spectrum of wellcontrolled conditions to better understand cell behaviour within 3D cultures such as stacked layers of cells or hydrogels. We have addressed the role of different ventral substrates, dorsal proteins and type of seeding (isolated vs wound healing). Overall, cell morphology was highly influenced by the type of culture whereas cell migration was determined by the inputs coming from both the ventral and dorsal substrate. This shows the high influence of the nano-bio-environment in cell fate. Furthermore, FN was reorganised in new fibrils when cells were dorsally stimulated within the sandwich culture (with the exception of PEA and PMA where FN is strongly adsorbed) suggesting that the dorsal excitation triggers different signalling to pure 2D conditions which leads to ECM reorganisation. Notably, this stimulation should be sought as a consequence of the mechanical microenvironment and not only of the biological input since uncoated dorsal substrates triggered the same response. 
Hence our results suggest that both biological and mechanical stimuli are playing an important role in cell migration since minimal changes led to different cell behaviour. This should be taken into account when comparing migration in 3D cultures that usually have different properties and consequently give rise to irreproducible results. For example, contradictory results have been shown regarding the cell speed when cultured within different 3D systems; however the origin of this difference has not been addressed. Deeper studies using sandwich culture might therefore shed some light in the cause of these differences and would be interesting for the understanding of cell behaviour under different types of 3D cultures.

\subsection{References}

1. Ridley AJ, Schwartz MA, Burridge K et al. Cell migration: integrating signals from front to back. Science. 2003;302:1704.

2. Cukierman E, Pankov R, Stevens DR, Yamada KM. Taking cellmatrix adhesions to the third dimension. Science. 2001;294:1708.

3. Lenaerts $\mathrm{T}$, Castagnetti $\mathrm{F}$, Traulsen $\mathrm{A}$ et al. Explaining the in vitro and in vivo differences in leukemia therapy. Cell Cycle. 2011;10:1540.

4. Zhang Z, Zhang ZY, Schluesener HJ. In vivo and in vitro differences between leukocytic uptake of oligodeoxynucleotides. Cell Mol Life Sci. 2008;65:1237.

5. Reig G, Pulgar E, Concha ML. Cell migration: from tissue culture to embryos. Development. 2014;141:1999.

6. Wolf K, Müller R, Borgmann S, Bröcker EB, Friedl P. Amoeboid shape change and contact guidance: T-lymphocyte crawling through fibrillar collagen is independent of matrix remodeling by MMPs and other proteases. Blood. 2003;102:3262.

7. Friedl P. Prespecification and plasticity: shifting mechanisms of cell migration. Curr Opin Cell Biol. 2004;16:14.

8. Wang W, Wyckoff JB, Frohlich VC, et al. Single cell behavior in metastatic primary mammary tumors correlated with gene expression patterns revealed by molecular profiling. Cancer Res. 2002;62:6278. 
9. Petrie RJ, Gavara N, Chadwick RS, Yamada KM. Nonpolarized signaling reveals two distinct modes of 3D cell migration. J Cell Biol. 2012;197:439.

10. Sanz-Moreno V, Gaggioli C, Yeo M et al. ROCK and JAK1 signaling cooperate to control actomyosin contractility in tumor cells and stroma. Cancer Cell. 2011;20:229.

11. Wolf K, Mazo I, Leung $\mathrm{H}$ et al. Compensation mechanism in tumor cell migration: mesenchymal-amoeboid transition after blocking of pericellular proteolysis. J Cell Biol. 2003;160:267.

12. Friedl $\mathrm{P}$, Wolf K. Plasticity of cell migration: a multiscale tuning model. J Cell Biol. 2010;188:11.

13. Schor SL, Ellis IR, Harada $\mathrm{K}$ et al. A novel 'sandwich' assay for quantifying chemo-regulated cell migration within 3-dimensional matrices: wound healing cytokines exhibit distinct motogenic activities compared to the transmembrane assay. Cell Motil Cytoskeleton. 2006;63:287.

14. Lee EJ, Hwang CM, Baek DH, Lee SH. Fabrication of microfluidic system for the assessment of cell migration on 3D micropatterned substrates. Conf Proc IEEE Eng Med Biol Soc. 2009;2009:6034.

15. Zaman MH, Trapani LM, Sieminski AL et al. Migration of tumor cells in 3D matrices is governed by matrix stiffness along with cellmatrix adhesion and proteolysis. Proc Natl Acad Sci U S A. 2006;103:10889.

16. Berginski ME, Gomez SM. The Focal Adhesion Analysis Server: a web tool for analyzing focal adhesion dynamics. F1000Research. 2013;2:68. http://faas.bme.unc.edu

17. Kam Y, Guess C, Estrada L, Weidow B, Quaranta V. A novel circular invasion assay mimics in vivo invasive behavior of cancer cell lines and distinguishes single-cell motility in vitro. BMC Cancer. 2008;8:198.

18. Lauffenburger DA, Horwitz AF. Cell migration: a physically integrated molecular process. Cell. 1996;84:359.

19. Ridley AJ, Schwartz MA, Burridge K et al. Cell migration: integrating signals from front to back. Science. 2003;302:1704. 
20. Decaestecker C, Debeir O, Van Ham P, Kiss R. Can anti-migratory drugs be screened in vitro? A review of 2D and 3D assays for the quantitative analysis of cell migration. Med Res Rev. 2007;27:149.

21. Fraley SI, Feng Y, Krishnamurthy R et al. A distinctive role for focal adhesion proteins in three-dimensional cell motility. Nat Cell Biol. 2010;12:598.

22. Ballester-Beltrán J, Lebourg M, Rico P, Salmerón-Sánchez M. Dorsal and ventral stimuli in cell-material interactions: effect on cell morphology. Biointerphases. 2012;7:39.

23. Ballester-Beltrán J, Lebourg M, Salmerón-Sánchez M. Dorsal and ventral stimuli in sandwich-like microenvironments. Effect on cell differentiation. Biotechnol Bioeng. 2013;110:3048.

24. Ballester-Beltrán J, Moratal D, Lebourg M, Salmerón-Sánchez M. Fibronectin-matrix sandwich-like microenvironments to manipulate cell fate. Biomater Sci. 2014;2:381.

25. Nagano M, Hoshino D, Koshikawa N, Akizawa T, Seiki M. Turnover of focal adhesions and cancer cell migration. Int J Cell Biol. 2012;2012:310616.

26. Pankov R, Endo Y, Even-Ram S et al. A Rac switch regulates random versus directionally persistent cell migration. J Cell Biol. 2005;170:793.

27. Beningo KA, Dembo M, Wang YL. Responses of fibroblasts to anchorage of dorsal extracellular matrix receptors. Proc Natl Acad Sci U S A. 2004;101:18024.

28. Hakkinen KM, Harunaga JS, Doyle AD, Yamada KM. Direct comparisons of the morphology, migration, cell adhesions, and actin cytoskeleton of fibroblasts in four different three-dimensional extracellular matrices. Tissue Eng Part A. 2011;17:713.

29. Ochsner M, Textor M, Vogel V, Smith ML. Dimensionality controls cytoskeleton assembly and metabolism of fibroblast cells in response to rigidity and shape. PLoS One. 2010;5:e9445.

30. Harunaga JS, Yamada KM. Cell-matrix adhesions in 3D. Matrix Biol. 2011;30:363.

31. Kim DH, Wirtz D. Focal adhesion size uniquely predicts cell migration. FASEB J. 2013;27:1351. 
32. Raeber GP, Lutolf MP, Hubbell JA. Molecularly engineered PEG hydrogels: a novel model system for proteolytically mediated cell migration. Biophys J. 2005;89:1374.

33. Collier IE, Wilhelm SM, Eisen AZ et al. H-ras oncogene-transformed human bronchial epithelial cells (TBE-1) secrete a single metalloprotease capable of degrading basement membrane collagen. J Biol Chem. 1998;263:6579.

34. Knäuper V, Cowell S, Smith B et al. The role of the C-terminal domain of human collagenase-3 (MMP-13) in the activation of procollagenase-3, substrate specificity, and tissue inhibitor of metalloproteinase interaction. J Biol Chem. 1997;272:7608.

35. Gugutkov D, Altankov G, Rodríguez Hernández JC, Monleón Pradas M, Salmerón Sánchez M. Fibronectin activity on substrates with controlled --OH density. J Biomed Mater Res A. 2010;92:322.

36. Mao Y, Schwarzbauer JE. Stimulatory effects of a three-dimensional microenvironment on cell-mediated fibronectin fibrillogenesis. J Cell Sci. 2005;118:4427.

37. Roca-Cusachs P, Iskratsch T, Sheetz MP. Finding the weakest link: exploring integrin-mediated mechanical molecular pathways. J Cell Sci. 2012;125:3025.

38. Doyle AD, Wang FW, Matsumoto K, Yamada KM. One-dimensional topography underlies three-dimensional fibrillar cell migration. J Cell Biol. 2009;184:481.

39. Ballester-Beltrán J, Rico P, Moratal D, Song W, Mano JF, SalmerónSánchez M. Role of superhydrophobicity in the biological activity of fibronectin at the cell-material interface. Soft Matter. 2011;7:10803

40. Rico P, Rodríguez Hernández JC, Moratal D et al. Substrate-induced assembly of fibronectin into networks: influence of surface chemistry and effect on osteoblast adhesion. Tissue Eng Part A. 2009;15:3271.

41. Ballester-Beltrán J, Cantini M, Lebourg M et al. Effect of topological cues on material-driven fibronectin fibrillogenesis and cell differentiation. J Mater Sci Mater Med. 2012;23:195. 
42. Salmerón-Sánchez M, Rico P, Moratal D, Lee TT, Schwarzbauer JE, García AJ. Role of material-driven fibronectin fibrillogenesis in cell differentiation. Biomaterials. 2011;32:2099.

43. Llopis-Hernández V, Rico P, Moratal D, Altankov G, SalmerónSánchez M. Role of material-driven fibronectin fibrillogenesis in protein remodeling. Biores Open Access. 2013;2:364. 


\section{Chapter 6. Induced C2C12 differentiation}

\section{Summary}

In this study we investigated the role of dorsal stimulation on myoblast differentiation within different poly(l-lactic acid) (PLLA) sandwich-like microenvironments, including plain material and aligned fibers. Enhanced cell differentiation levels were found for cells cultured with dorsal fibronectin-coated films. Seeking to understand the underlying mechanisms, experiments were carried out with (i) different types of dorsal stimuli (FN, albumin, FN after blocking the RGD integrin-binding site and activating dorsal cell integrin receptors), (ii) in the presence of an inhibitor of cell contractility and (iii) increasing the frequency of culture medium changes to assess the effect of paracrine factors. Furthermore, FAK and integrin expressions, determined by western blotting, revealed differences between cell sandwiches and 2D controls. Results show a stimuli-dependent response to dorsal excitation, proving that integrin outside-in signalling is involved in the enhanced cell differentiation.

* Results presented in this chapter have been partially published in: Ballester-Beltrán J, Lebourg M and Salmerón-Sánchez M. Dorsal and ventral stimuli in sandwich-like microenvironments. Effect on cell differentiation. Biotechnol Bioeng. 2013; 110, 3048-3058. 



\subsection{Introduction}

The nature of the cell-protein-material interaction directs myogenesis by regulating cell adhesion and its signalling pathways. ${ }^{1,2}$ For instance, focal adhesion kinase (FAK) can interact with the growth factor receptor-bound protein 2 (GRB2), ${ }^{3}$ thus linking integrin signalling to the ras/MAP kinase pathway which plays an important role in myoblast differentiation. ${ }^{4}$ So integrin stimulation via cell adhesion controls cell proliferation and differentiation. Although myogenesis is a $3 \mathrm{D}$ process, it has been commonly studied on flat substrates (2D) -where only ventral adhesion is permitted- thus imposing an unnatural environment that differs from the natural 3D extracellular matrix (ECM). ${ }^{5,6}$ Likewise, 3D cultures closer to the physiological environment are more and more preferred to study cellular processes in vitro, including matrix secretion, cell differentiation, morphogenesis, cancer research and drug development. ${ }^{7-10}$ In the same way, during this chapter, we want to address the effect of the dorsal stimulation on myogenic differentiation.

To do so we have studied myoblast differentiation in a sandwichlike culture where cells were seeded in different poly(L-lactic acid) (PLLA) sandwich-like cultures and fibronectin (FN) was used as extracellular matrix protein. Both flat PLLA samples $(p)$ and aligned microfibers of PLLA (a) were used. Consequences of dorsal stimuli on FAK signalling pathway and specific integrin anchorage were furthermore determined. As sandwich culture showed to enhance $\mathrm{C} 2 \mathrm{C} 12$ differentiation, additional experiments were designed to get further insights into this process: dorsal stimulation with non-adhesive proteins (BSA), blocking the RGD integrinbinding domain of the dorsal FN and activating dorsal integrins with functional antibodies for $\alpha_{5}$ and $\beta_{3}$ integrin subunits. Moreover, the role of the RhoA pathway was studied using a contractility inhibitor, as well as the influence of paracrine factor secretion. 


\subsection{Materials and methods}

\subsubsection{Materials}

Figure 6.1 depicts the different conditions used for the sandwich culture during this chapter. For more detailed protocols please see chapter 3.

A

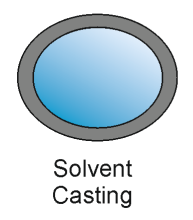

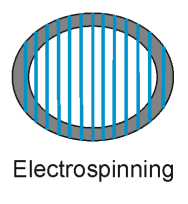

B

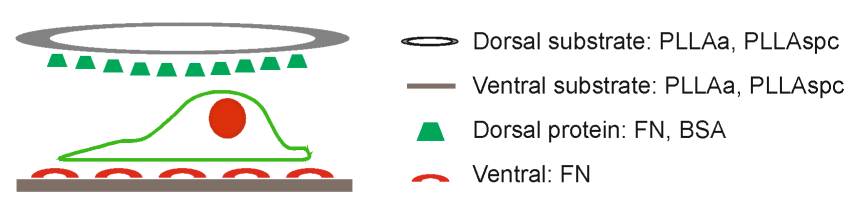

Figure 6.1. Sandwich-like culture. (A) Dorsal substrates used during this chapter: plane PLLA solvent casting and aligned electrospun PLLA fibers. (B) Sketch of the sandwich-like model and the different combinations for each component (protein and material substrates). Fibronectin was always used as coating protein unless otherwise noted.

\subsubsection{Cell culture}

Murine C2C12 myoblasts were maintained in Dulbecco's Modified Eagle Medium (DMEM) supplemented with 20\% fetal bovine serum and $1 \%$ penicillin-streptomycin (Lonza). C2C12 cells were seeded at 17,500 cells $/ \mathrm{cm}^{2}$ in DMEM without serum supplemented with $1 \%$ penicillinstreptomycin and 1\% insulin-transferrin-selenium-X (Invitrogen) in order to induce myogenic differentiation. Sandwich cultures (SW) were established after 3 hours of 2D culture (unless otherwise noted). Similarly as in the previous chapter, a specific nomenclature was used overall the study: $\mathrm{SW}_{x} y$ with $x$-ventral and $y$-dorsal material conditions. Protocols are explained in more detail in chapter 3 .

For experiments including dorsal activation with antibodies, blocking antibodies were added after $5 \mathrm{~min}$ of culture and removed after 3 hours. Antibodies against $\alpha_{5}$ integrin (CD 49e, clon SAM-01, Immunotech) and against $\beta_{3}$ integrin (CD61, clon SZ21, Immunotech) were used for functional assay at $0.62 \mathrm{ug} / \mathrm{mL}$.

When blocking the RGD specific adhesion site, dorsal substrates were incubated after FN adsorption with antibody HFN7.1 
(Developmental Studies Hybridoma Bank) at $7.3 \mu \mathrm{g} / \mathrm{mL}$ during 1 hour and then washed two times in DPBS before cell culture.

For experiments including contractility inhibitor, Y-27632 (Sigma) was added to culture medium (10 and $20 \mu \mathrm{M})$ after 2 hours of culture and maintained for 4 days.

Finally, to study the effect of the paracrine factor secretion, medium was changed every 12 hours whereas in control samples medium was changed every two days as usual.

\subsection{Results and discussion}

\subsubsection{Materials characterisation}

During this work we have used plain PLLA (samples indexed with $p$ ) and aligned fibers of PLLA (samples indexed with $a$ ) seeking to obtain cell alignment and more physiological-like myotubes. To better characterise the sandwich culture, both plane and aligned fibers samples were used as ventral and as dorsal substrates so that their influence depending on the dimensionality was assessed.

Solvent casted films with a thickness of $4.88 \mu \mathrm{m} \pm 1.6 \mu \mathrm{m}$ and homogenous electrospun straight fibers of PLLA with dimension of 145.4 $\pm 2.7 \mathrm{~nm}$ high and $173.8 \pm 0.7 \mathrm{~nm}$ wide were obtained. As expected, aligned fibers display a characteristic peak after spectral analysis due to a highly anisotropic organisation (Figure 6.2A). AFM was used to investigate FN distribution on substrates. As expected, both plain PLLA $(\mathrm{C}+p)$ and aligned PLLA fibers $(\mathrm{C}+a)$ showed globular molecules of FN (Figure 6.2B and reference 11). 


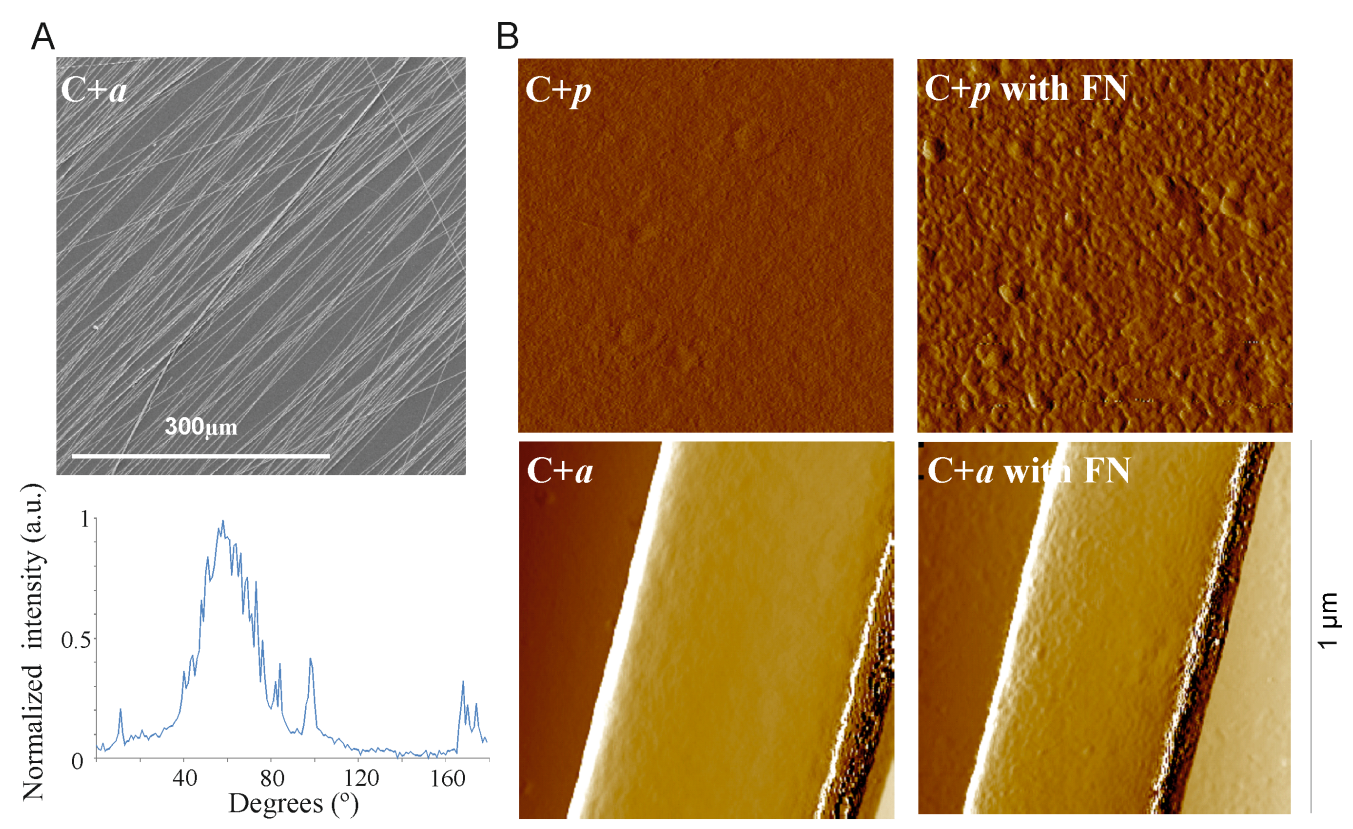

Figure 6.2. Materials characterisation. (A) Aligned PLLA fibers as observed by SEM and radial projection of the image (Fast Fourier Transform of the normalized pixel intensity), demonstrating fiber alignment. (B) Fibronectin distribution as observed by AFM with respect to the control surface without fibronectin. Globular FN molecules are observed on plane and aligned PLLA substrates (pointed out with white arrows).

\subsubsection{Initial spreading and morphology; dorsal and ventral cues}

Cell area and roundness were evaluated for the different conditions to study the influence of the sandwich-like culture on cell morphology. To do so, cell morphology was studied at 3 different time points: (i) 3 hours of culture (just before establishing the sandwich culture so that this point is common for 2D and SW samples), (ii) 6 hours (in order to check the early effect of the sandwich culture) and (iii) 24 hours (to study the late effect of the sandwich). Similarly as shown before for NIH3T3 fibroblasts overlaid with a PLLA film (chapter 4),12 cells spread similarly on 2D and sandwichlike cultures (figure 6.3A and raw data in reference 11). Two main groups can be clearly differentiated: cells seeded on $\mathrm{C}+a$ are significantly less spread than cells seeded on $\mathrm{C}+p$ (Figure 6.3A). Importanly, this difference can be observed in both control and sandwich cultures. This result suggests that cell alignment on the ventral fibers limits cell spreading by 
directing cell elongation along the fibers. This is also shown when cells seeded on $\mathrm{C}+p$ are sandwiched with FN-coated aligned fibers as the upper substrate $\left(\mathrm{SW}_{p}{ }^{a}\right)$ since cells randomly spread on $\mathrm{C}+p$ start aligning in the direction of the upper fibers resulting in diminished spread area (Figure 6.3B).

Similarly, cell alignment influences cell roundness. Cells are more rounded on $\mathrm{C}+p$ than on $\mathrm{C}+a$. Likewise, cells sandwiched with dorsal aligned fibers $\left(\mathrm{SW}_{p}{ }^{a}\right)$ are significantly less rounded than sandwiched inbetween plain substrates $\left(\mathrm{SW}_{p} p\right)$, with roundness close to the cells on $\mathrm{C}+a$. By contrast, when dorsal PLLA fibers are coated with the non-adhesive bovine serum albumin (BSA) instead of FN -so that cells cannot adhere to the dorsal substrate-, no cell alignment was achieved even after 2 days of culture (figure 6.3B, $\mathrm{SW}_{p}{ }^{a-B S A}$ ). Notwithstanding, cells seeded on aligned fibers did not lose alignment orientation after sandwiching with plain PLLA coated with FN $\left(\mathrm{SW}_{a}^{p}\right)$, revealing the distinct competition between ventral and dorsal stimuli in determining cell fate. In the same way, cells seeded on $\mathrm{C}+a$ and afterwards sandwiched using aligned dorsal fibers perpendicularly oriented to the ventral ones $\left(\mathrm{SW}_{a^{a}}{ }^{\perp}\right)$, remained aligned along the ventral fibers and do not react to the dorsal ones, ${ }^{11}$ revealing the importance of the initial ventral input. Similar results were later obtained by the group of Teruro Okano when stacking cell sheets with different orientations, and hence corroborating not only our results but also the hypothesis that sandwich culture offers an environment closer to the 3D than $2 \mathrm{D}$ substrates do. ${ }^{13}$ 
A
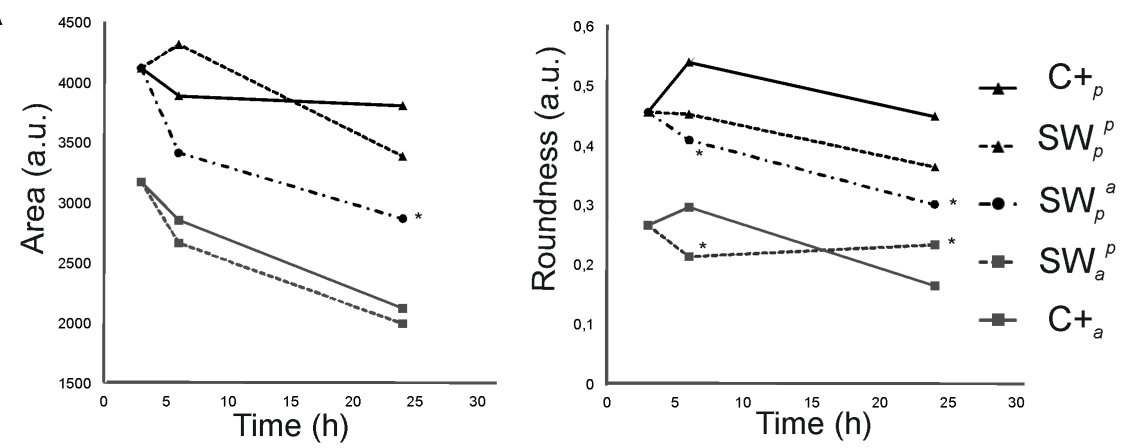

B

$$
\mathrm{C}+{ }_{p}(3 \mathrm{~h})
$$

$\mathrm{C}+{ }_{a}(3 h)$
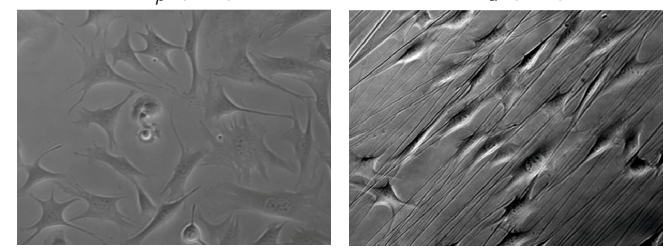

$\operatorname{SW}_{p}^{a}(1 \mathrm{~d})$

$S W_{p}^{a-B S A}(2 d)$
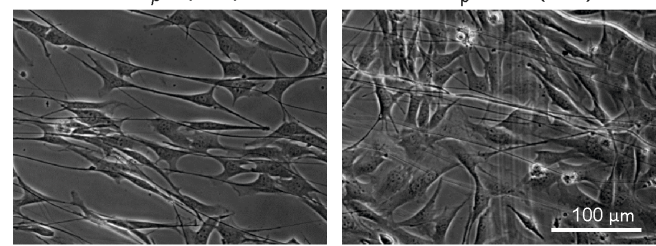

Figure 6.3. Cell morphology for different sandwich-like cultures. (A) Cell area and roundness time dependence for the different culture conditions. Numerical values are shown in reference 11 . Statistically significant differences with the control, at every culture time, are indicated with * $\mathrm{P}<0.05$. (B) Bright field images show the effect of dorsal and ventral material fibers on cell alignment dependence. Dotted lines represent fibers orientation where necessary. Time of culture is written in brackets for each condition.

In summary, cell morphology depends on both dorsal and ventral topological cues as sensed by the cells through the intermediate layer of proteins at the material interface. In this way, the competition between the ventral and dorsal inputs will determine the final cell morhology. 


\subsubsection{Dorsal stimuli enhance myogenic differentiation}

We next examined the role of dorsal stimuli on cell differentiation by quantifying the sarcomeric myosin positive cells (figure 6.4). Similar differentiation levels were found on both $2 \mathrm{D}$ substrates $(\mathrm{C}+p$ and $\mathrm{C}+a)$ and the type I collagen control (ca. $34.8 \% \pm 7.7$ ), which is considered to be the gold-standard substrate for myogenic differentiation. ${ }^{14,15}$ It is convenient to remark here that, in order to facilitate comparisons, cell differentiation levels calculated across this chapter have been normalized to collagen I unless otherwise mentioned. As seen before for other substrates, even though myoblast alignment is mandatory for their fusion into myotubes, directing their alignment by using electrospun fibers $(\mathrm{C}+a)$ did not promote any significant enhancement of cell differentiation (figure 6.4B). ${ }^{15-17}$ In contrast, $\mathrm{C} 2 \mathrm{C} 12$ sandwiched with a plain substrate showed significantly enhanced differentiation levels $(\mathrm{p}<0.001)$ regardless the topology of the ventral substrate (that is to say, regarding having plain or aligned fibers of PLLA as ventral substrate; $\mathrm{SW}_{p}^{p}$ and $\mathrm{SW}_{a}^{p}$ respectively). Interestingly, this enhancement in myogenic differentiation was not seen when aligned fibers were used as the dorsal substrate (figure $6.4 \mathrm{C}, \mathrm{SW}_{p}{ }^{a}$ ), which suggests (i) competition between cell alignment and cell differentiation in a similar way as it happens between cell migration and cell differentiation ${ }^{15,18}$ and/or (ii) effect of the total cell stimulated area since plane PLLA (PLLAfilm) offers more adhesion area than the electrospun fibers so that more dorsal receptors can be activated. Thus, cell differentiation might be delayed in $\mathrm{SW}_{p}{ }^{a}$ as a consequence of cell alignment along the dorsal PLLA fibers before starting the differentiation program (figure 6.3). Actually, whereas cells seeded within $\mathrm{SW}_{p}{ }^{p}$ form myotubes on day 2, only isolated cells can be observed on 2D substrates at that time and not fully aligned cells are seen within $\mathrm{SW}_{p^{a}}{ }^{11}$ Sandwich culture can therefore tune differentiation dynamics -either accelerating or delaying it- regarding topological cues. 
A
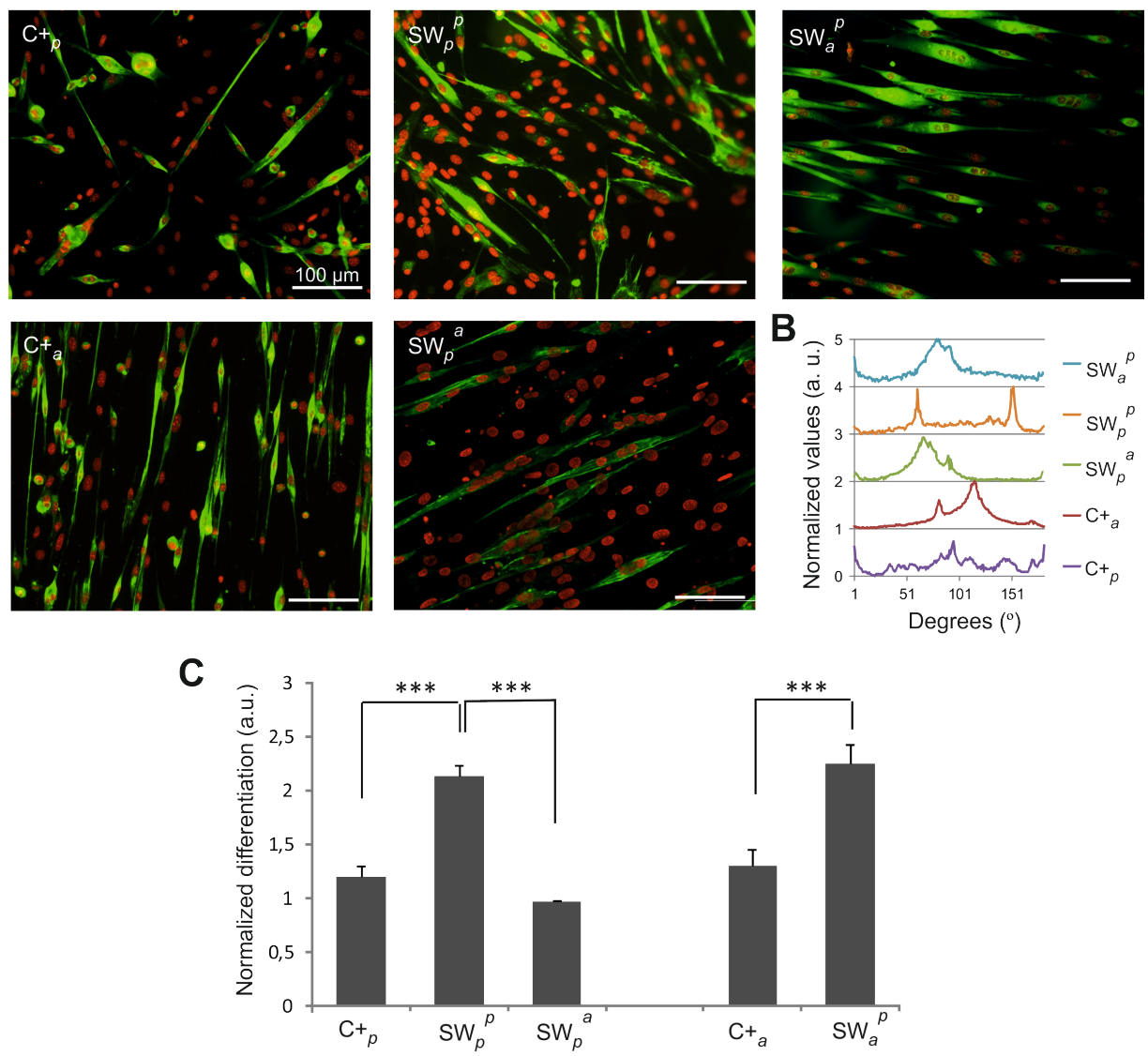

Figure 6.4. Cell differentiation in sandwich-like cultures after 4 days of culture. (A) Fluorescence staining showing sarcomeric myosin positive cells (green) and cell nuclei (red). (B) Orientation of differentiated cells as calculated by image analysis (FFT of the normalized pixel intensity). (C) Myogenic differentiation levels as determined by the percentage of sarcomeric myosin-positive cells. Statistically significant differences with respect to the control are indicated with $* * * \mathrm{P}<0.001$.

To better characterise this enhanced myogenic differentiation within sandwich environments, cells were cultured on $\mathrm{C}+p$ and within $\mathrm{SW}_{p}{ }^{p}$ with growth medium (20\% FBS), which is known to block myogenic differentiation and trigger proliferation. As figure 6.5 shows, no myotubes can be seen on 2D substrates whereas long and well-developed ones are observed within $\mathrm{SW}_{p}{ }^{p}$. Dorsal stimulation may therefore trigger this 
enhancement in myogenic differentiation, probably as a consequence of the dorsal receptors stimulation. Actually, after this work, ${ }^{11}$ A. J. Garcia and co-workers demonstrated that exposure to extra RGD domains during the first $6 \mathrm{~h}$ of culture -so similarly as happens in the sandwich cultureleads to an increase in the myogenic differentiation levels of C2C12 cells. ${ }^{19}$
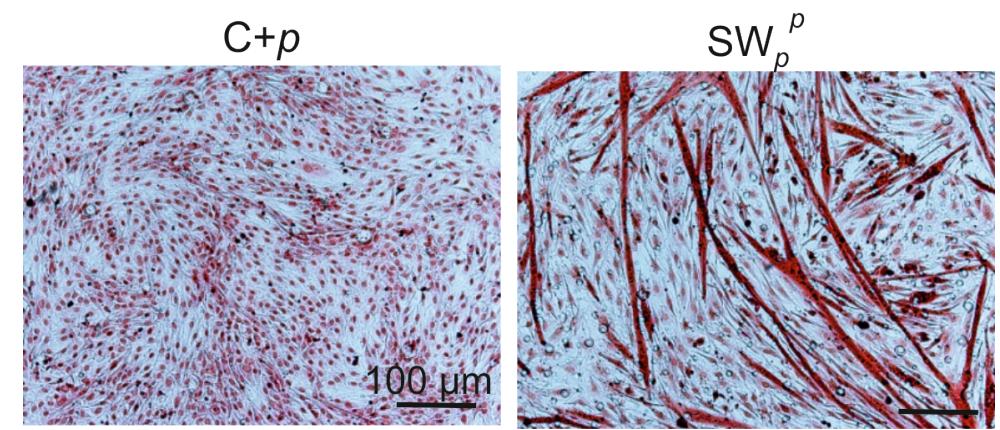

Figure 6.5. Cell morphology after 4 days in growth media. Neutral red staining shows long myotubes were only developed in $\mathrm{SW}_{p^{p}}$ samples.

Our previous results on sandwich-like cultures with fibroblasts showed the key effect of the initial ventral material interaction before dorsal stimulation in cell response (Chapter 4).12, 20 Consequently, establishing the sandwich culture either immediately after cell seeding or after 3 hours of 2D culture may influence myoblast differentiation. This can be qualitatively explained in the context of cell tensegrity models. ${ }^{21}$ Our results shows that sandwiching cells with a plain PLLA film immediately after cell seeding $\left(\mathrm{SW}_{p}{ }^{p-t 0}\right)$ resulted in development of long pseudopodia after 6 hours of culture (figure 6.6A). Furthermore, $\mathrm{SW}_{p}{ }^{p-t 0}$ did not achieve the enhanced differentiation levels shown in sandwiches established after 3 hours of ventral adhesion $\left(\mathrm{SW}_{p}{ }^{p}\right.$ ) (figure 6.6B), ${ }^{11}$ what now can be suggested to be a consequence of the extra exposure of cell binding domains during the first hours of the culture within SW culture (after $3 \mathrm{~h}$ of ventral adhesion). ${ }^{19}$ 
A
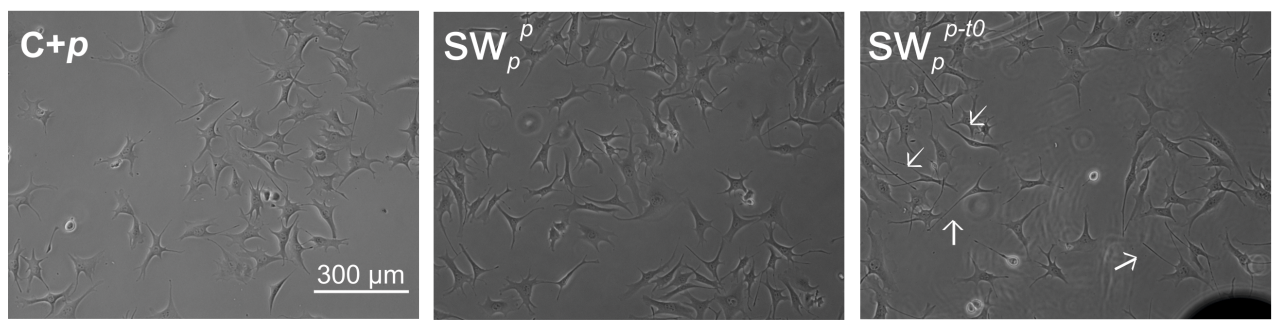

B
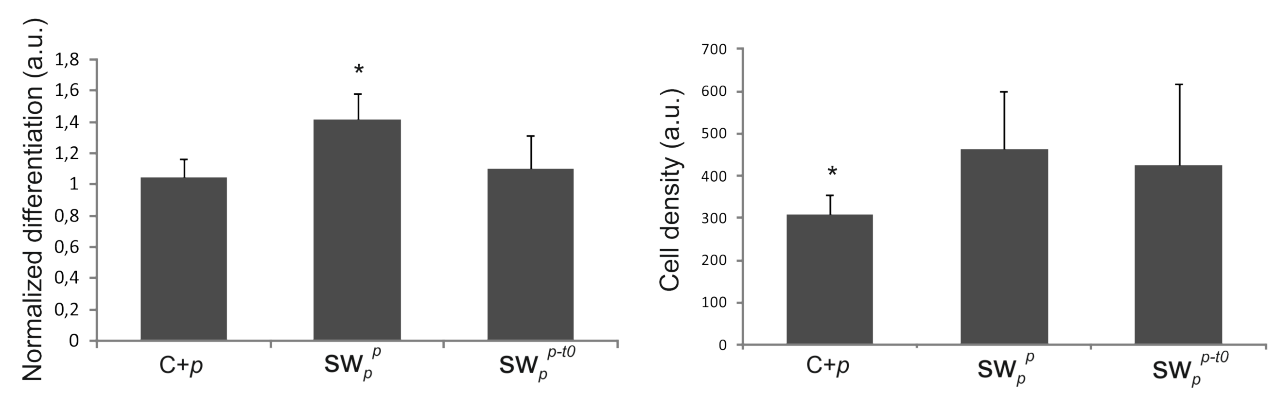

Figure 6.6. C2C12 in sandwich-like cultures established just after cell seeding $\left(\mathrm{SW}_{p^{p-t}}\right)$. (A) Cell morphology after 6 hours of culture. (B) Cell differentiation and density. Statistically significant differences are indicated with ${ }^{* *} \mathrm{P}<0.05$.

Previous studies demonstrated the effect of myoblast seeding density on the ability to fuse into myotubes in a range that difficults cellcell contact and fusion at the lowest densities. ${ }^{22,23}$ In our case the same initial cell density was used throughout all the experiments. However modest cell density differences exist between 2D and sandwich cultures after 4 days of culture (when cell differentiation was assessed). Bajaj P et al. showed that this level of modest differences for cell density (while seeding at the same cell density) is poorly correlated with the differentiation level. ${ }^{24}$ Actually, differences in cell density are not correlated with cell differentiation in our results (see figure 6.6). ${ }^{11}$ So we suggest that these small differences on cell density exist probably due to the fact that cells are easier removed during medium changes when cultured on 2D conditions. 
Finally, one could disregard either hypoxia or mechanical pressure within the sandwich culture as external stimuli able to account for enhanced differentiation level. However such kind of stimuli has been shown to handicap myogenic differentiation and if this were the case $\mathrm{SW}_{p}{ }^{p-t 0}$ should have given rise to an enhance in myogenic differentiation (figure 6.6). ${ }^{25-27}$ On the other hand, it is known that myoblast fate is closely bound to integrin involvement and expression, ${ }^{28}$ and that changes in integrin expression and focal adhesion signalling might influence myogenic differentiation. ${ }^{28-31}$ Thus we hypothesize that upon sandwiching, the excitation of the dorsal receptors may trigger the enhanced cell differentiation in sandwich-like cultures. Support for this hypothesis will be afterwards provided.

\subsubsection{Integrin expression and cell signalling}

Cell adhesion by integrin-ECM interaction triggers a cascade of intracellular signals such as the p38 mitogen-activated protein kinase (p38 MAPK) pathway. This signalling pathway is involved in the myoblast differentiation process by promoting the activity of several transcription factors and regulating cell cycle withdrawal. ${ }^{28,32}$ The intermediary step between MAPK pathways and adhesion is the phosphorylation of FAKs. ${ }^{33}$ As a result, FAK phosphorylation at Tyr-397 plays a central role during myoblast differentiation in 2D cultures. ${ }^{34,} 35$ During myogenesis, FAK phosphorylation at Tyr-397 is transiently reduced initially -contributing to trigger the myogenic genetic program- but later it is activated to achieve fully differentiated myotubes. ${ }^{35}$ As cells cultured on sandwich-like cultures interact with both the ventral and dorsal substrates, FAK activation might occur on both sides, triggering signalling pathways that may differ from the standard 2D one. In order to study the activation of FAK we examined its phosphorylation by western blot and immunofluorescence. 
After 6 hours of culture, FAK phosphorylation was significantly diminished in sandwich cultures as compared to the corresponding 2D control, both for the plain $\left(\mathrm{SW}_{p}^{p}\right)$ and aligned PLLA ventral surfaces $\left(\mathrm{SW}_{a}{ }^{p}\right)$ (figure 6.7A). This result supports the known relationship between enhanced myogenic differentiation and pFAK decrease at the beginning of the process. ${ }^{35,36}$ Strikingly, immunodetection of FAK phosphorylation at Tyr 925 -which is known to trigger a Ras-dependent activation of the MAP kinase pathway-3 showed increased brushstroke-like labeling within sandwich-like cultures (figure 6.8). ${ }^{11}$ This initially controversial result,

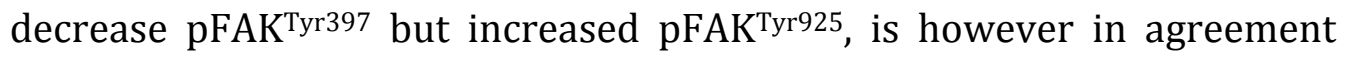
with the enhanced phosphorylation of downstream MAPK showed by Yamada et al. in 3D systems ${ }^{37}$ and with the fact that the phosphorilation of Tyr-925 residue has been identified to be processed in a different way than other Tyr residues of FAK. ${ }^{38}$ So, these results suggest that enhanced cell differentiation upon dorsal and ventral stimulation in our sandwichlike system may be due to a shift in response from 2D to 3D-like, and not only to the excitation of a larger number of cell adhesion receptors (due to the increased surface in contact as a result of dorsal interaction) in a mere 2D manner. 
A

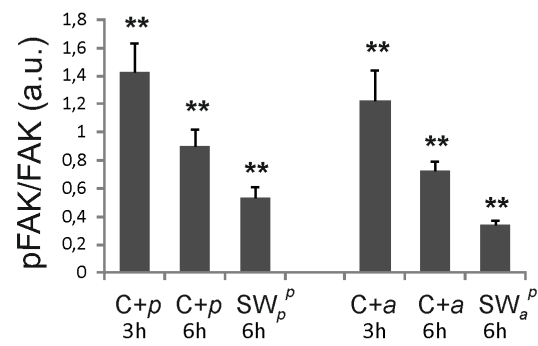

B

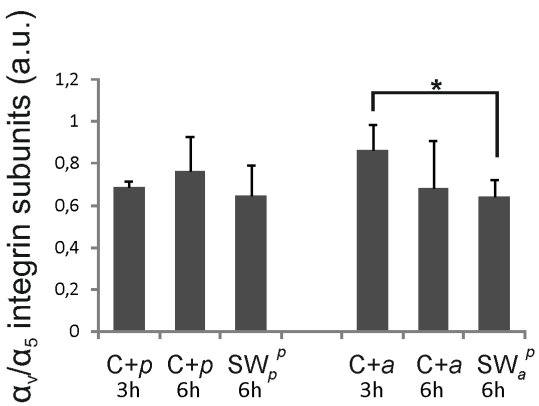

C

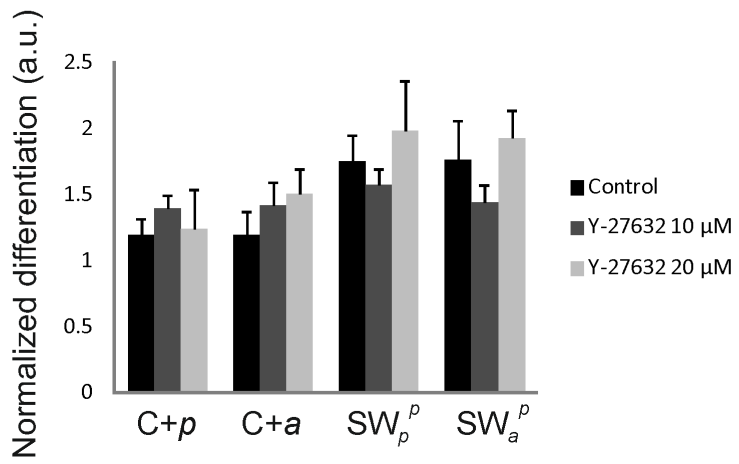

Figure 6.7. Effect of dorsal stimuli on FAK phosphorylation and integrin expression after $6 \mathrm{~h}$ of culture ( $3 \mathrm{~h}$ of dorsal stimuli in sandwich-like culture) and effect of cell contractility inhibitor on myogenic differentiation. Western blot quantification of (A) the fraction of phosphorylated FAK at Tyr397 and (B) the ratio $\alpha_{\mathrm{v}} / \alpha_{5}$ integrin subunits. (C) Effect of the contractility inhibitor Y-27632 on cell differentiation. Statistically significant differences are indicated with $* \mathrm{P}<$ 0.05 and $^{* *} \mathrm{P}<0.01$.

As some studies suggest that 3D matrix-adhesions of fibroblast are mainly developed through $\alpha_{5}$ integrin subunits, ${ }^{36}$ integrin expression after 6 hours of culture was studied in order to determine whether dorsal interactions in sandwich-like cultures trigger any specific integrin expression. So, $\alpha_{5}$ and $\alpha_{\mathrm{v}}$ integrin subunits were quantified by western blot techniques for each culture condition since $\alpha_{5} \beta_{1}$ and $\alpha_{v} \beta_{3}$ integrins are the major integrins anchoring to $\mathrm{FN}$ and are known to influence in the differentiation process. No significant differences were observed, so the $\alpha_{v} / \alpha_{5}$ integrin subunits ratio was similar for 2D and sandwich-like cultures (figure 6.7B), unlike what was seen in chapter 4 for NIH3T3 
fibroblasts, suggesting therefore to be cell line dependent or consequence of the differentiation process.

Cell contractility is known to also influence C2C12 differentiation under certain conditions. ${ }^{30}$ In order to examine whether the enhanced myogenic differentiation within sandwiches was due to an increase in cell contractility, cells were cultured in the presence of Y-27632, a Rho/ROCK pathway contractility inhibitor. As figure 6.7C shows, the inhibitor did not cause any significant change in cell differentiation in neither the plain $\left(\mathrm{SW}_{p}{ }^{p}\right)$ nor the aligned $\left(\mathrm{SW}_{a}^{p}\right)$ sandwich conditions, and as expected nor on $2 \mathrm{D}$ substrates. ${ }^{30}$ Thus enhanced myogenic differentiation in sandwichlike conditions is not a consequence of increased cell contractility due to dorsal stimuli.
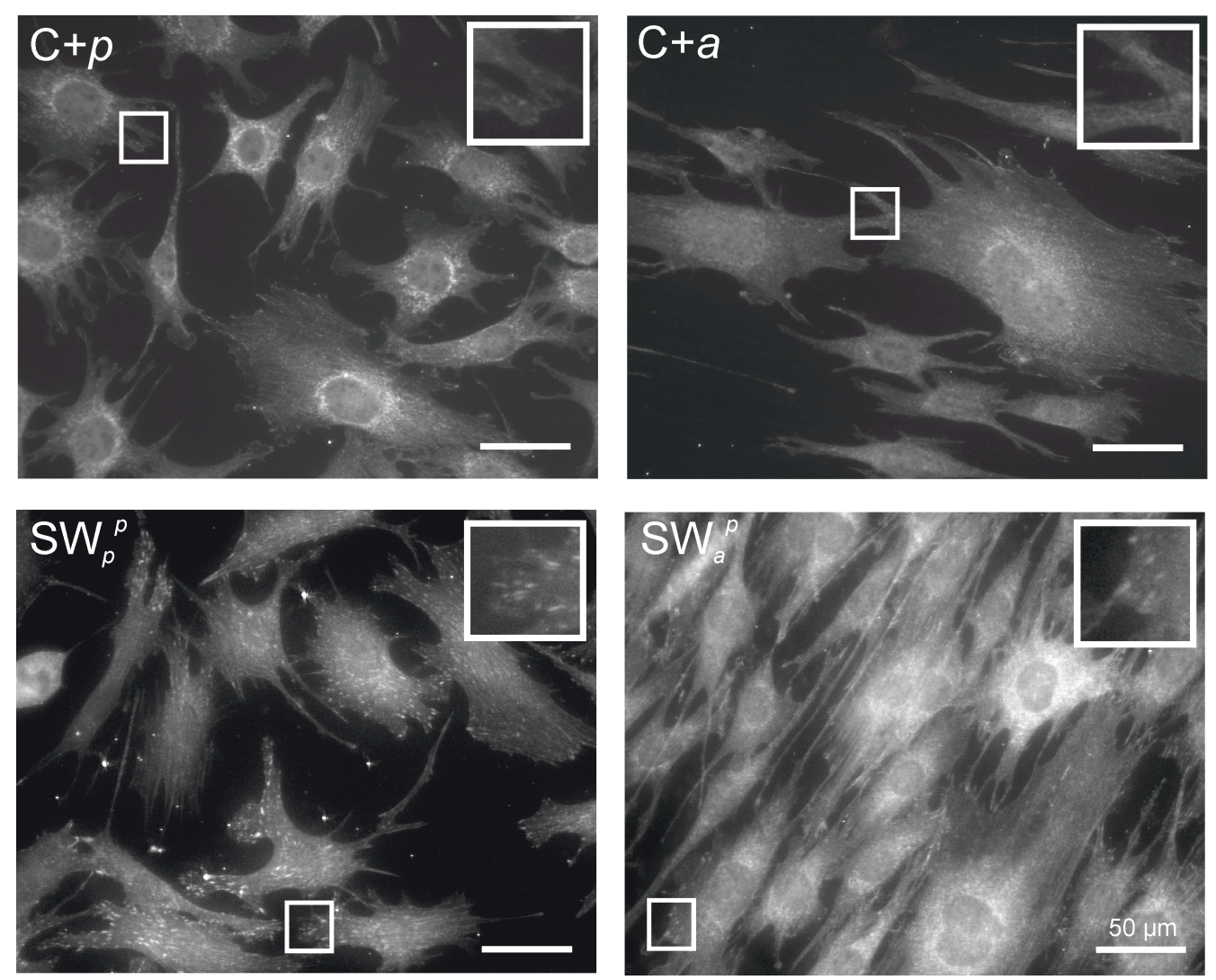

Figure 6.8. pFAK (Tyr925) immunolocalization for the different culture conditions. Magnifications of the images have been inserted to better notice differences of pFAK (Tyr925) localization. 


\subsubsection{Dorsal integrins and cell differentiation}

To clarify whether the enhanced levels of myodifferentiation in sandwichlike conditions is a direct consequence of a biological cell-protein-material interaction or if by contrast its origin must be sought as a mere physical interaction with the material surface, we used BSA -a non-adhesive protein-39-41 instead of FN to coat the upper substrate of the sandwich construct. This condition $\left(\mathrm{SW}_{p}{ }^{p-B S A}\right)$ resulted in lower cell differentiation compared with the standard plain sandwich-like system $\left(\mathrm{SW}_{p}{ }^{p}\right)$ coated with FN on both sides (figure 6.9). Nevertheless, cell differentiation in $\mathrm{SW}_{p}{ }^{p-B S A}$ was still higher than on plain $2 \mathrm{D}$ controls. This result suggests that the enhanced differentiation observed in (FN-coated) sandwich-like culture must be sought, at least partially, in dorsal-integrin activation. Moreover, that cell differentiation levels in $\mathrm{SW}_{p}{ }^{p-B S A}$ does not match those obtained for 2D controls can be a consequence of self-secreted ECM proteins such as FN or procollagen, ${ }^{42,} 43$ which might displace and hide previously adsorbed BSA on the dorsal material surface and thus provide dorsal-integrin stimuli on cells. The time needed to secrete the ECM and displace the adsorbed FN might be the reason why cell differentiation levels remain below FN coated sandwiches. 
A
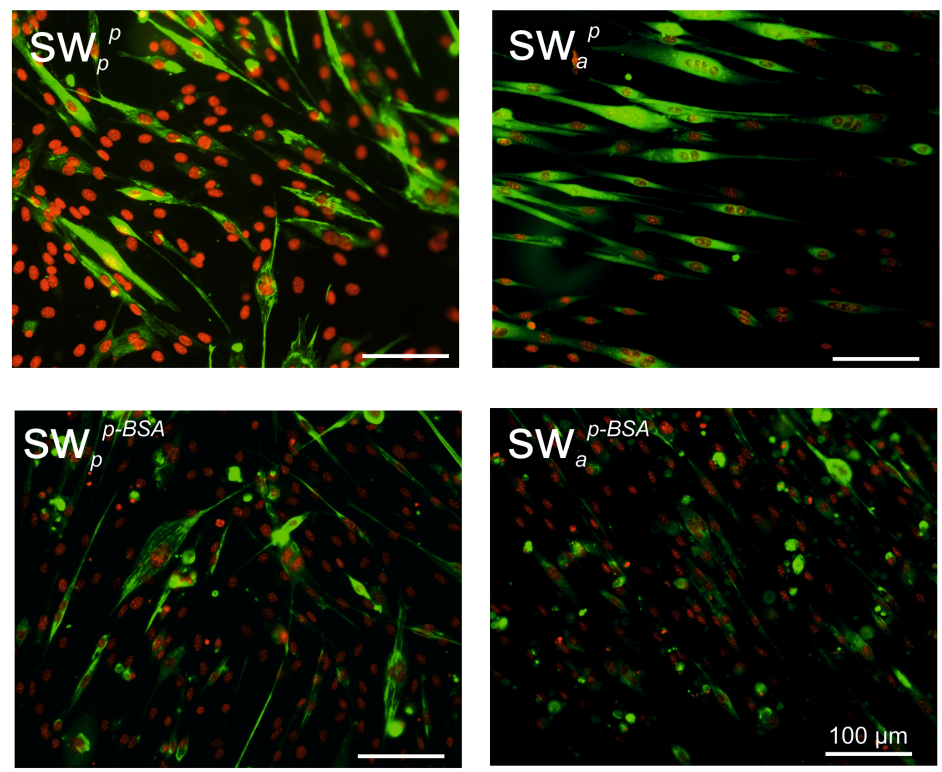

B

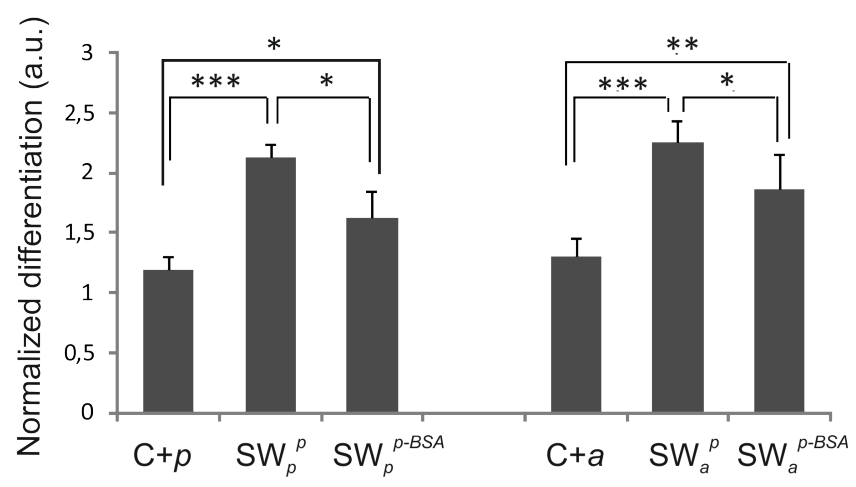

Figure 6.9. Cell differentiation at day 4 with BSA-coated substrates as dorsal stimuli. (A) Fluorescence staining showing sarcomeric myosin-positive cells (green) and cell nuclei (red). (B) Myogenic differentiation as determined by the percentage of sarcomeric myosin-positive cells. Statistically significant differences are indicated with ${ }^{*} \mathrm{P}<0.05,{ }^{* *} \mathrm{P}<0.01$, and ${ }^{* * *} \mathrm{P}<0.001$.

To get further insights into the underlying mechanism of the enhance myodifferentiation, we blocked the integrin-binding site of FN adsorbed on the dorsal substrate before cell sandwiching using the HFN7.1 antibody. This antibody binds the FN III9-10 domain, thus blocking possible interactions with PSHRN and RGD, main cell binding domains. Dorsal $\alpha_{5} \beta_{1}$ integrin interaction is therefore prevented but just partially in 
the case of $\alpha_{v} \beta_{3}$ as another specific $\alpha_{v} \beta_{3}$ integrin binding domain exists in FN. ${ }^{44,45}$ Blocking the dorsal RGD domain is therefore similar to the $\mathrm{SW}_{F N}{ }^{B S A}$ condition (since dorsal cell adhesion is hindered) but in this case initial dorsal adhesion can be still take place by $\alpha_{v} \beta_{3}$ integrin. Figure 6.10A shows that myoblast differentiation was significantly enhanced after blocking the integrin binding site in dorsal-FN as compared with standard sandwich conditions. Thus, binding of $\alpha_{v} \beta_{3}$ to FN by the specific cell-adhesion domain ${ }^{45}$ is triggering an outside-in signalling that induces differentiation more than interaction at FN III9-10 site does, leading to this enhance in myodifferentiation. $\beta_{3}$ integrin has been recently linked to myogenic differentiation though $\beta_{1}$ has been the most studied integrin involved in the process. ${ }^{31,46}$ This results suggest therefore the possible role of $\beta_{3}$ in the myodifferentiation process. However other possibilities may be the binding of other cell surface receptors (syndecans, M-cadherin, etc. ${ }^{47}$ ) with their corresponding outside-in signalling, or the interaction of vacant dorsal integrins $\alpha_{5} \beta_{1}$ and $\alpha_{v} \beta_{3}$ with distinct cell-secreted factors (soluble or adsorbed to the dorsal material). These hypothesis are moreover not exclusive, what difficults even more its understanding.

In order to better characterise this process, cells were stimulated with functional antibodies for either $\beta_{3}$ or $\alpha_{5}$ shortly after seeding on 2D substrate in order to mimic the material-driven activation of dorsal integrins within the sandwich-like culture. Antibody-activated dorsal integrins did not trigger the same signal as simply sandwiching since cell differentiation levels were significantly higher for $\mathrm{SW}_{p} p$ than in any other condition of the experiment (figure 6.10B). Nevertheless $\beta_{3}$ integrin activation (without sandwiching) on the dorsal side led to a significant increase in cell differentiation compared to 2D (note that a non-significant increase in cell differentiation was obtained after stimulating the $\alpha_{5}$ receptor). This result shows that activation of dorsal receptors is absolutely involved in enhanced cell differentiation and points towards a possible role of $\alpha_{\mathrm{v}} \beta_{3}$ activation as previously commented. As integrin activation on 2D samples increased differentiation levels but do not level them to sandwich cultures values, we questioned the role of the dorsal substrate: was it necessary just as a physical stimulus (applying some stress on the cells for example) or as a biophysical stimuli (as cells sense 
the difference between mere activation by a soluble antibody and the binding to a structure resisting tension, for example the protein coating)?. Sandwiching cells after dorsal integrin activation did not produced any improved differentiation compared to the activation condition without sandwiching, suggesting that the increase in differentiation may be directly linked to a biophysical effect of the dorsal integrin activation state. Indeed, different states of activation may be provoked by integrin binding to FN adsorbed on a rigid surface when compared with a blocking antibody, and may not provoke the same "outside-in" signalling cascades. ${ }^{48}$ This difference in local dorsal stiffness is likely to stimulate different mechanotransductive pathways for sandwich-like and 2D cultures, as previously reported for stem cells and C2C12 cells in 2D conditions. ${ }^{49,50}$ In summary, dorsal-antibody stimulation on cells cultured on 2D conditions partially mimics the effect of dorsal interaction with adsorbed FN in sandwich-like cultures, thus the effect on cell differentiation is much lower.

A

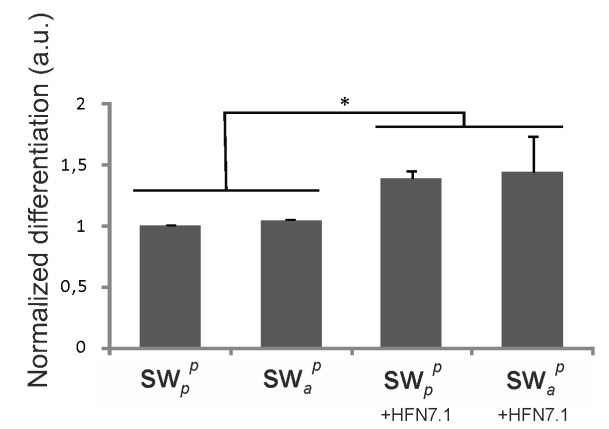

B

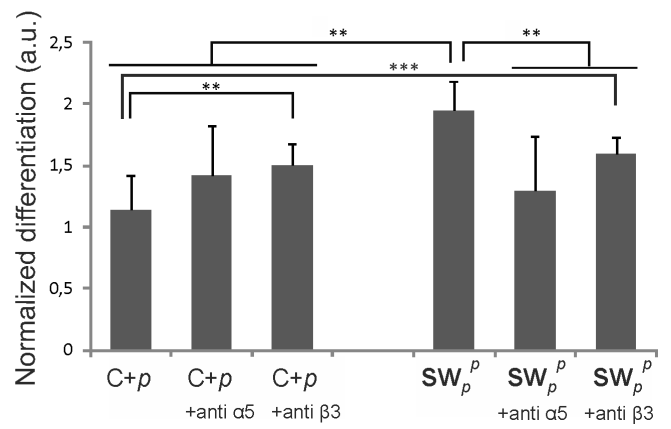

Figure 6.10. Effect of integrin-mediated dorsal interaction on myogenic differentiation after 4 days of culture. (A) Effect of blocking the integrin-binding domain of FN adsorbed on the dorsal substrate (data normalized to $\mathrm{SW}_{p} p$ ). (B) Effect of dorsal integrin activation using anti- $\alpha_{5}$ or anti- $\beta_{3}$ antibodies. Statistically significant differences are indicated with ${ }^{*} \mathrm{P}<0.05,{ }^{* *} \mathrm{P}<0.01$, and ${ }^{* *} \mathrm{P}<0.001$. 


\subsubsection{Release of paracrine factors}

We have shown dorsal estimulation triggered different integrin expression and FAK phosphorilation. We wonder now whether dorsal activation within sandwich culture may modify also growth factor expression since several growth factors (GFs) can stimulate or inhibit myogenesis in an autocrine or paracrine manner. For instance, insulin-like growth factors (IGFs) and tumor necrosis factor (TNF) stimulate myoblast differentiation via IGF-1 receptor and p38 MAPK pathway activation respectively, ${ }^{51-55}$ whereas fibroblast growth factor (FGF) and transforming growth factor- $\beta$ (TGF- $\beta$ ) among others inhibit myogenesis. ${ }^{56,57}$ Since medium diffusion within sandwich cultures is somehow restricted compared to standard 2D conditions, we planned a cell differentiation experiment with increased frequency of culture medium changes in order to determine if the enhanced cell differentiation was also related to the accumulation of cell-secreted factors within the sandwich structure. Figure 6.11 shows that increasing medium changes in control 2D conditions does not modify levels of cell differentiation but cell density is drastically reduced due to the aspiration of weakly attached cells during medium changes. On the other hand and as commented before, cell density is maintained in sandwich cultures due to the protection of the dorsal substrate that impedes aspiration of cells. Moreover, differentiation levels of sandwiches with frequently medium changes are reduced down to 2D control levels. Altogether, these results suggest that enhanced differentiation during sandwich-like experiments may be correlated with the production of soluble paracrine factors different than those secreted in standard 2D cultures or at different concentrations. This different GFs secretion is moreover a consequence of integrin-mediated dorsal stimulation since different dorsal stimuli caused different myodifferentiation levels. Besides growth factors could be retained within sandwich cultures increasing their local activity. 

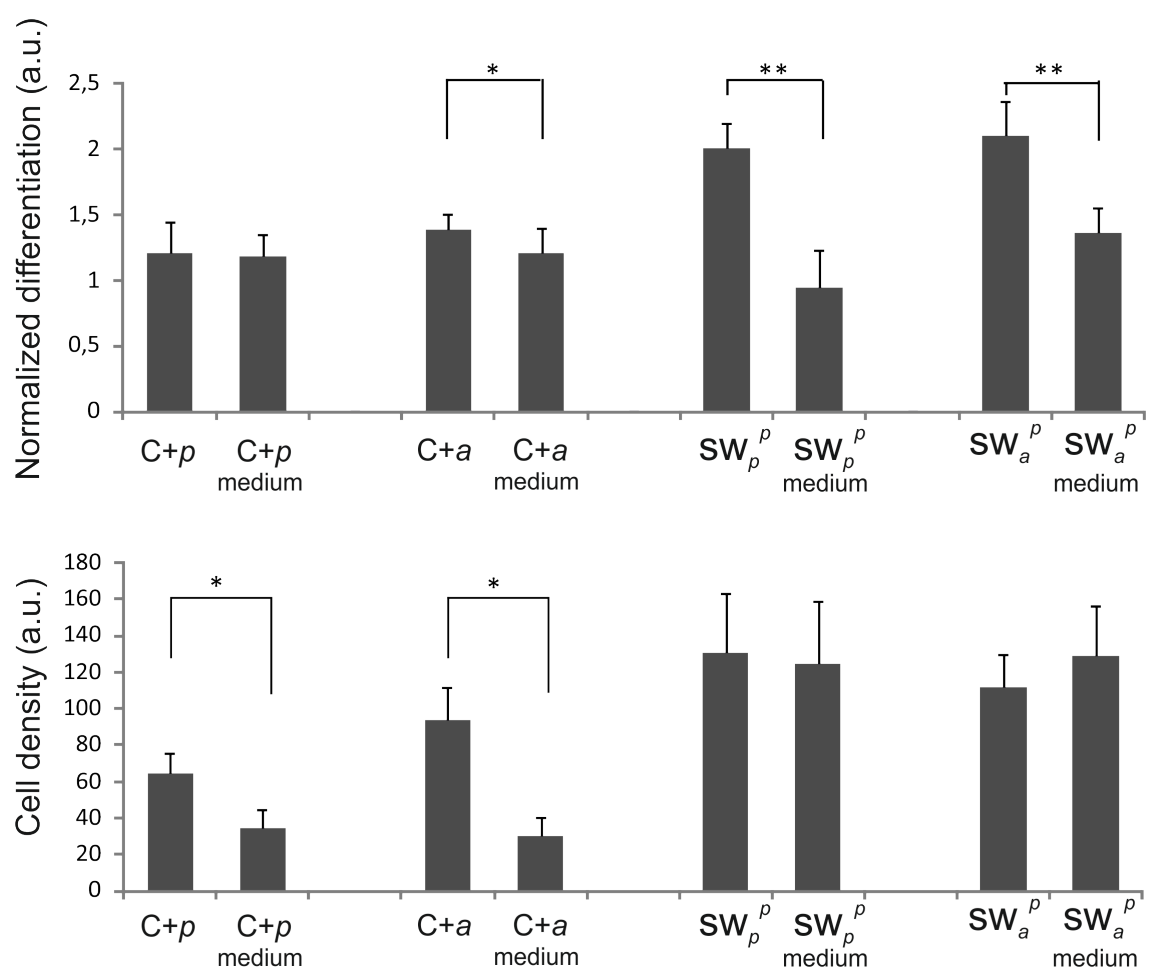

Figure 6.11. Effect of secreted paracrine factors on cell differentiation and cell density by comparing results of the experiment with frequent (labeled as medium) and standard medium changes. Statistically significant differences are indicated with ${ }^{*} \mathrm{P}<0.05,{ }^{* *} \mathrm{P}<0.01$, and ${ }^{* * *} \mathrm{P}<0.001$.

\subsection{Conclusions}

During this chapter we have observed that cell morphology was easily tuned by topological cues within sandwich cultures and cell differentiation -upon dorsal and ventral stimulation within sandwich-like cultures- was enhanced compared to standard 2D cultures. This enhanced myogenic differentiation was shown to be a consequence of the synergistic superposition of different events that occurs upon stimulation of dorsal integrin receptors. Coating the dorsal substrate with BSA -to prevent integrin binding- did not reach the same differentiation level than sandwiches, but it was still higher than the corresponding 2D control. Likewise, stimulating the dorsal receptors with integrin antibodies specially with anti- $\beta_{3}$ - increased cell differentiation above the $2 \mathrm{D}$ control, but below the standard sandwich conditions. This result, in context with 
the super-enhanced cell differentiation found after sandwiching with the integrin-binding domain of FN blocked (by HFN7.1 antibody), revealed the distinctive role of the $\beta_{3}$ integrin interaction in sandwich-like cultures, since this integrin can interact with FN via other domain available beyond FN III9-10 (blocked by the HFN7.1 antibody). Besides, cell contractility was not involved in this enhanced myogenesis within the sandwich environment, as the addition of Y-27632 did not alter the differentiation level. Finally, the role of paracrine factors distinctively released within the cell culture in sandwich conditions as a consequence of this differential integrin activation through the FN-coated dorsal material surfaces was clearly revealed, suggesting a link between dorsal integrins excitation and growth factor release. Overall, the stimulation of dorsal $\alpha_{v} \beta_{3}$ integrins seems to have a preponderant role that needs to be further explored since $\alpha_{5} \beta_{1}$ has been commonly the main integrin related with myogenesis. The fact that the myogenic process is not fully understood yet even on 2D substrates and that unknown differences may exist between 2D and 3D cultures (among them differences in the interplay of the multiple cellular pathways involved) hamper the unequivocal interpretation of all the parameters involved in the myogenic differentiation. Nevertheless, this study has pointed out important relations between dorsal stimulation and cell behaviour but further experiments are necessary for the better understanding of the process.

Finally, we have shown again that cell morphology and signalling within the sandwich constructs share some similarities with 3D cultures, supporting the hypothesis that sandwich-like culture can be used as an intermediate model linking 2D and 3D cultures thus providing further insights into the role of dimensionality in cell-material interactions. 


\subsection{References}

1. Meighan CM, Schwarzbauer JE. Temporal and spatial regulation of integrins during development. Curr Opin Cell Biol. 2008;20:520.

2. Streuli $\mathrm{CH}$. Integrins and cell-fate determination. J Cell Sci. 2009;122:171.

3. Schlaepfer DD, Hanks SK, Hunter T, van der Geer P. Integrinmediated signal transduction linked to Ras pathway by GRB2 binding to focal adhesion kinase. Nature. 1994;372:786.

4. Bennett AM, Tonks NK. Regulation of distinct stages of skeletal muscle differentiation by mitogen-activated protein kinases. Science. 1997;278:1288.

5. Lewis WH, Lewis MR. Behavior of cells in tissue cultures. In: General Cytology. The University of Chicago Press, Chicago. 1924:385

6. Weiss P. Cellular dynamics. Rev Mod Phys. 1959;31:11

7. House M, Daniel J, Elstad K, Socrate S, Kaplan DL. Oxygen tension and formation of cervical-like tissue in two-dimensional and threedimensional culture. Tissue Eng Part A. 2012;18:499.

8. Hutmacher DW. Biomaterials offer cancer research the third dimension. Nat Mater. 2010;9:90.

9. Lutolf MP, Hubbell JA. Synthetic biomaterials as instructive extracellular microenvironments for morphogenesis in tissue engineering. Nat Biotechnol. 2005;23:47.

10. Rimann M, Graf-Hausner U. Synthetic 3D multicellular systems for drug development. Curr Opin Biotechnol. 2012;23:803.

11. Ballester-Beltrán J, Lebourg M, Salmerón-Sánchez M. Dorsal and ventral stimuli in sandwich-like microenvironments. Effect on cell differentiation. Biotechnol Bioeng. 2013;11:3048

12. Ballester-Beltrán J, Moratal D, Lebourg M, Salmerón-Sánchez M. Fibronectin-matrix sandwich-like microenvironments to manipulate cell fate. Biomater. Sci. 2014;2:381.

13. Takahashi H, Shimizu T, Nakayama M, Yamato M, Okano T. The use of anisotropic cell sheets to control orientation during the selforganization of 3D muscle tissue. Biomaterials. 2013;34:7372. 
14. García AJ, Vega MD, Boettiger D. Modulation of cell proliferation and differentiation through substrate-dependent changes in fibronectin conformation. Mol Biol Cell. 1999;10:785.

15. Ballester-Beltrán J, Cantini M, Lebourg M, Rico P, Moratal D, García AJ, Salmerón-Sánchez M. Effect of topological cues on materialdriven fibronectin fibrillogenesis and cell differentiation. J Mater Sci Mater Med. 2012;23:195.

16. Wakelam MJ. The fusion of myoblasts. Biochem J. 1985;228:1.

17. Charest JL, García AJ, King WP. Myoblast alignment and differentiation on cell culture substrates with microscale topography and model chemistries. Biomaterials. 2007;28:2202.

18. Tse JR, Engler AJ. Stiffness gradients mimicking in vivo tissue variation regulate mesenchymal stem cell fate. PLoS One. 2011;6:e15978.

19. Weis S, Lee TT, del Campo A, García AJ. Dynamic cell-adhesive microenvironments and their effect on myogenic differentiation. Acta Biomater. 2013;9:8059.

20. Ballester-Beltrán J, Lebourg M, Rico P, Salmerón-Sánchez M. Dorsal and ventral stimuli in cell-material interactions: effect on cell morphology. Biointerphases. 2012;7:39.

21. Ingber DE. Tensegrity I. Cell structure and hierarchical systems biology. J Cell Sci. 2003;116:1157.

22. Tanaka K, Sato K, Yoshida T, Fukuda T, Hanamura K, Kojima N, Shirao T, Yanagawa T, Watanabe H. Evidence for cell density affecting C2C12 myogenesis: possible regulation of myogenesis by cell-cell communication. Muscle Nerve. 2011;44:968.

23. Smith AS, Passey S, Greensmith L, Mudera V, Lewis MP. Characterization and optimization of a simple, repeatable system for the long term in vitro culture of aligned myotubes in 3D. J Cell Biochem. 2012;113:1044.

24. Bajaj P, Reddy B Jr, Millet L, Wei C, Zorlutuna P, Bao G, Bashir R. Patterning the differentiation of $\mathrm{C} 2 \mathrm{C} 12$ skeletal myoblasts. Integr Biol (Camb). 2011;3:897. 
25. Boonen KJ, Langelaan ML, Polak RB, van der Schaft DW, Baaijens FP, Post MJ. Effects of a combined mechanical stimulation protocol: Value for skeletal muscle tissue engineering. J Biomech. 2010;43:1514.

26. Di Carlo A, De Mori R, Martelli F, Pompilio G, Capogrossi MC, Germani A. Hypoxia inhibits myogenic differentiation through accelerated MyoD degradation. J Biol Chem. 2004;279:16332.

27. Li X, Wang X, Zhang P. Hypoxia inhibits differentiation of C2C12. Zhongguo Ying Yong Sheng Li Xue Za Zhi. 2008;24:267.

28. Sastry SK, Lakonishok M, Wu S, Truong TQ, Huttenlocher A, Turner CE, Horwitz AF. Quantitative changes in integrin and focal adhesion signaling regulate myoblast cell cycle withdrawal. J Cell Biol. 1999;144:1295.

29. Belkin AM, Zhidkova NI, Balzac F, Altruda F, Tomatis D, Maier A, Tarone G, Koteliansky VE, Burridge K. Beta 1D integrin displaces the beta $1 \mathrm{~A}$ isoform in striated muscles: localization at junctional structures and signaling potential in nonmuscle cells. J Cell Biol. 1996;132:211.

30. Salmerón-Sánchez M, Rico P, Moratal D, Lee TT, Schwarzbauer JE, García AJ. Role of material-driven fibronectin fibrillogenesis in cell differentiation. Biomaterials. 2011;32:2099.

31. Liu H, Niu A, Chen SE, Li YP. Beta3-integrin mediates satellite cell differentiation in regenerating mouse muscle. FASEB J. 2011;25:1914.

32. Mancini A, Sirabella D, Zhang W, Yamazaki H, Shirao T, Krauss RS. Regulation of myotube formation by the actin-binding factor drebrin. Skelet Muscle. 2011;1:36.

33. Chatzizacharias NA, Kouraklis GP, Theocharis SE. Disruption of FAK signaling: a side mechanism in cytotoxicity. Toxicology. 2008;245:1.

34. Clemente CF, Corat MA, Saad ST, Franchini KG. Differentiation of C2C12 myoblasts is critically regulated by FAK signaling. Am J Physiol Regul Integr Comp Physiol. 2005;289:R862.

35. Quach NL, Rando TA. Focal adhesion kinase is essential for costamerogenesis in cultured skeletal muscle cells. Dev Biol. 2006;293:38. 
36. Cukierman E, Pankov R, Stevens DR, Yamada KM. Taking cellmatrix adhesions to the third dimension. Science. 2001;294:1708.

37. Cukierman E, Pankov R, Yamada KM. Cell interactions with threedimensional matrices. Curr Opin Cell Biol. 2002;14:633.

38. Brunton VG, Avizienyte E, Fincham VJ, Serrels B, Metcalf CA 3rd, Sawyer TK, Frame MC. Identification of Src-specific phosphorylation site on focal adhesion kinase: dissection of the role of $\mathrm{Src} \mathrm{SH} 2$ and catalytic functions and their consequences for tumor cell behavior. Cancer Res. 2005;65:1335.

39. Curtis AS, Forrester JV. The competitive effects of serum proteins on cell adhesion. J Cell Sci. 1984;71:17.

40. Tamada Y, Ikada Y. Effect of Preadsorbed Proteins on Cell Adhesion to Polymer Surfaces. J Colloid Interf Sci. 1993;155:334.

41. Zelzer M, Albutt D, Alexander MR, Russell NA.. The Role of Albumin and Fibronectin in the Adhesion of Fibroblasts to Plasma Polymer Surfaces. Plasma Process Polym. 2012;9:149.

42. Kislinger T, Gramolini AO, Pan Y, Rahman K, MacLennan DH, Emili A. Proteome dynamics during C2C12 myoblast differentiation. Mol Cell Proteomics. 2005;4:887.

43. Chan XC, McDermott JC, Siu KW. Identification of secreted proteins during skeletal muscle development. J Proteome Res. 2007;6:698.

44. Schoen RC, Bentley KL, Klebe RJ. Monoclonal antibody against human fibronectin which inhibits cell attachment. Hybridoma. 1982;1:99.

45. Sottile J, Hocking DC, Langenbach KJ. Fibronectin polymerization stimulates cell growth by RGD-dependent and -independent mechanisms. J Cell Sci. 2000;113:4287.

46. Yu H, Lui YS, Xiong S, Leong WS, Wen F, Nurkahfianto H, Rana S, Leong DT, Ng KW, Tan LP. Insights into the role of focal adhesion modulation in myogenic differentiation of human mesenchymal stem cells. Stem Cells Dev. 2013;22:136.

47. Peckham M. Engineering a multi-nucleated myotube, the role of the actin cytoskeleton. J Microsc. 2008;231:486.

48. Wei WC, Lin HH, Shen MR, Tang MJ. Mechanosensing machinery for cells under low substratum rigidity. Am J Physiol Cell Physiol. 2008;295:C1579. 
49. Engler AJ, Sen S, Sweeney HL, Discher DE. Matrix elasticity directs stem cell lineage specification. Cell. 2006;126:677.

50. Ren K, Crouzier T, Roy C, Picart C. Polyelectrolyte multilayer films of controlled stiffness modulate myoblast cells differentiation. Adv Funct Mater. 2008;18:1378.

51. Haba G de la, Cooper GW, Elting V. Hormonal requirements for myogenesis of striated muscle in vitro: insulin and somatotropin. Proc Natl Acad Sci U S A. 1966;56:1719.

52. Florini JR, Magri KA. Effects of growth factors on myogenic differentiation. Am J Physiol. 1989;256:C701.

53. Chen SE, Jin B, Li YP. TNF-alpha regulates myogenesis and muscle regeneration by activating p38 MAPK. Am J Physiol Cell Physiol. 2007;292:C1660.

54. Li YP, Schwartz RJ. TNF-alpha regulates early differentiation of C2C12 myoblasts in an autocrine fashion. FASEB J. 2001;15:1413.

55. Florini JR, Ewton DZ, Magri KA. Hormones, growth factors, and myogenic differentiation. Annu Rev Physiol. 1991;53:201.

56. Clegg $\mathrm{CH}$, Linkhart TA, Olwin BB, Hauschka SD. Growth factor control of skeletal muscle differentiation: commitment to terminal differentiation occurs in G1 phase and is repressed by fibroblast growth factor. J Cell Biol. 1987;105:949.

57. Evinger-Hodges MJ, Ewton DZ, Seifert SC, Florini JR. Inhibition of myoblast differentiation in vitro by a protein isolated from liver cell medium. J Cell Biol. 1982;93:395. 


\section{Chapter 7. Spontaneous cell differentiation}

\section{Summary}

We have previously shown sandwich culture triggers an increase in C2C12 myogenic differentiation. We wonder now whether this sandwich culture strictly directs differentiation towards the myogenic lineage or not. To do so we have studied differentiation of cells cultured in growth media in order to avoid preferential differentiation towards specific phenotypes. We first worked with C2C12 cells as they can differentiate towards osteogenic and myogenic lineages. Then we studied human mesenchymal stem cells (hMSCs) since these cells can differentiate towards a broader number of lineages. Furthermore we used hMSC from different sources (bone marrow and adipose tissue) and selected with different multipotency markers in order to investigate its correlation with the differentiation outcome. Results show that sandwich culture triggers C2C12 myogenic over osteogenic differentiation. However, hMSC differentiation highly depends on the source and selection process and it is not always towards the myogenic lineages.

*Results presented in this chapter were obtained during an internship at the Center for Cell Engineering (Institute of Molecular Cell and Systems Biology, University of Glasgow, UK) under the supervision of Prof. Matthew Dalby. 



\subsection{Introduction}

Stem cells remain in their niche as slow proliferating, metabolically quiescent cells in order to maintain their multipotency and be ready when required. Understanding their niche and the activation pathways will help therefore in the development of more relevant 3D cultures for tissue engineering and stem cell technologies. ${ }^{1}$ Currently, strategies to maintain multipotent cell populations or direct its differentiation typically rely on complex and poorly understood cocktails of soluble factors that either slow down proliferation to maintain the multipotency or induce specific cell differentiation. More recently strategies are based on either mimicking different characteristics of the in vivo niche ${ }^{2,3}$ or modulating the cell/material interaction (and thus the outside-in signaling and cell fate). ${ }^{4-6}$ Thus, sandwich culture becomes an interesting approach to study the differentiation of multipotent cells under a closer 3D environment.

We have shown in chapter 6 that sandwich culture triggers C2C12 myogenic differentiation. Now we wonder whether the sandwich microenvironment promotes other types of cell differentiation or whether it strictly directs differentiation towards the myogenic lineage.

Here we have studied cell differentiation within sandwich culture using growth medium so that preferential differentiation towards specific lineages is avoided. We first investigated $\mathrm{C} 2 \mathrm{C} 12$ cells as they differentiate towards the osteogenic and myogenic lineage. Then we studied human mesenchymal stem cells (hMSCs) since these cells can differentiate towards additional lineages such as the chondrogenic, adipose, neural etc., ${ }^{7}$ as a clinically relevant cellular source for regenerative medicine. ${ }^{8-10}$ Furthermore, MSCs tend to spontaneously differentiate when cultured on traditional tissue culture plastics in vitro resulting in a heterogeneous population with diminished multipotency. This MSC differentiation has been shown to be highly influenced by the cell/material interface, ${ }^{2,5,6}$ so we wonder how sandwich culture environment influences this process. Additionally, since hMSC can be obtained from different sources and selected with different markers of multipotency, resulting populations might have different multipotenty/differentiation abilities. This is the 
reason why here we studied hMSCs from 4 different sources (2 obtained from bone marrow versus 2 from adipose tissue; at the same time 2 of them were commercial pre-selected cells versus the other 2 unselected cell populations obtained from patients). By doing so we want to assess any correlation between cell source, sandwich culture and cell differentiation. hMSC differentiation towards different lineages was studied by gene expression (qPCR) and immunofluorescence.

\subsection{Materials and methods}

\subsubsection{Materials}

PLLA was used as ventral and dorsal substrate. Furthermore, PLLA was always coated with FN as better explained in chapter 3 .

A

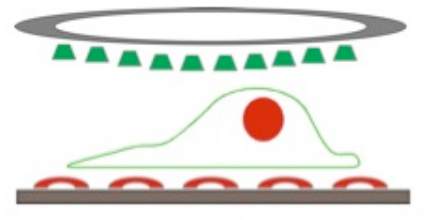

$\longrightarrow$ Dorsal substrate: PLLAfilm

- Ventral substrate: PLLAspc

- Dorsal protein: FN

- Ventral: $\mathrm{FN}$

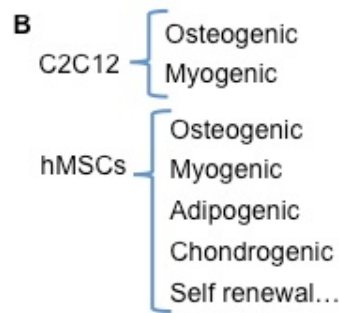

Figure 7.1. Sketch of the sandwich-like culture. (A) Substrates and protein coatings used during this work. (B) C2C12 and hMSCs potential differentiation lineages.

\subsubsection{Cell culture}

Murine C2C12 myoblasts were maintained in Dulbecco's Modified Eagle Medium (DMEM) supplemented with $20 \%$ fetal bovine serum and $1 \%$ penicillin-streptomycin (Lonza). C2C12 cells were seeded at 17,500 cells $/ \mathrm{cm}^{2}$ in serum-free DMEM in order to direct specific adhesion to the FN coating. Sandwich cultures were obtained by overlaying the FN-coated PLLA film over the cells after 3 hours of culture. Media changes were performed at day 2 of culture and differentiation controls were performed using induction media (table 7.1). Finally, after 4 days of culture, differentiation towards osteogenic and myogenic lineages was assessed by ALP staining and sarcomeric myosin positive cell detection respectively (chapter 3). 
Human mesenchymal stem cells (hMSCs) were obtained either from PromoCell (C-12975 and C-12978; Germany) or extracted from normal patients undergoing surgery (table 7.3). In this last case, human osteoprogenitors were extracted from bone marrow samples obtained from haematologically normal patients undergoing routine hipreplacement surgery whereas human adipoprogenitors were obtained from lipoaspirates. MSCs were maintained in Dulbecco's Modified Eagle Medium (DMEM) supplemented with $10 \%$ fetal bovine serum and $1 \%$ of antibiotic mix (L-Glutamine $200 \mu \mathrm{M}$ (Sigma), penicillin/streptomycin $(10,000 \mathrm{u} / \mathrm{mL}$; Sigma) and fungizone $(250 \mu \mathrm{g}$ of amphotericin B/mL; Invitrogen) in a ratio 15:10:1.25). Cells were sub-cultured when approximately $80 \%$ confluent. hMSCs between passage 1 and 4 were seeded at 5,000 cells $/ \mathrm{cm}^{2}$ in serum-free DMEM in order to direct specific adhesion to the FN. Positive differentiation controls for the immunodetection of the differentiation markers were performed by using induction media (table 7.1). In the case of the adipogenic differentiation, 2 different media were used alternatively and continuously during the culture: induction media (for 3 days) and then maintenance media (for 4 days). Media changes were performed twice weekly. Gene expression analysis by qPCR was performed as detailed in chapter 3. 
Table 7.1. Growth and induction media used during the culture of the different cell lines.

\begin{tabular}{|c|c|}
\hline \multicolumn{2}{|l|}{ C2C12 } \\
\hline Growth Media & DMEM with $20 \%$ FBS and $1 \% \mathrm{P} / \mathrm{S}$ \\
\hline Myogenic & DMEM with $1 \% \mathrm{P} / \mathrm{S}$ and $1 \%$ ITS-X \\
\hline Osteogenic & DMEM with $1 \% \mathrm{P} / \mathrm{S}$ and $150 \mathrm{ng} / \mathrm{mL} \mathrm{BMP} 2$ \\
\hline \multicolumn{2}{|l|}{ hMSCs } \\
\hline Growth media & DMEM with $10 \%$ FBS and $1 \%$ antibiotic mix \\
\hline Myogenic & DMEM with $2 \%$ FBS, $1 \%$ antibiotic mix and $1 \%$ ITS-X \\
\hline Osteogenic & $\begin{array}{l}\text { DMEM with } 10 \% \text { FBS, } 1 \% \text { antibiotic mix, } 0.1 \mu \mathrm{M} \\
\begin{array}{l}\text { dexamethasone and } 350 \mu \mathrm{M} \text { L-ascorbic acid } 2 \text { - } \\
\text { phosphate }\end{array}\end{array}$ \\
\hline $\begin{array}{l}\text { Adipogenic } \\
\text { (induction) }\end{array}$ & $\begin{array}{l}\text { DMEM with } 10 \% \text { FBS, } 1 \% \text { antibiotic mix, } 1 \mu \mathrm{M} \\
\text { dexamethasone, } 1.7 \mu \mathrm{M} \text { insulin, } 200 \mu \mathrm{M} \text { indomethacin } \\
\text { and } 500 \mu \mathrm{M} \text { isobutylmethylxanthine }\end{array}$ \\
\hline $\begin{array}{l}\text { Adipogenic } \\
\text { (maintenance) }\end{array}$ & $\begin{array}{l}\text { DMEM with } 10 \% \text { FBS, } 1 \% \text { antibiotic mix and } 1.7 \mu \mathrm{M} \\
\text { insulin }\end{array}$ \\
\hline
\end{tabular}

\section{Immunofluorescence}

MSCs cultured for 14 days were fixed in $4 \%$ Formaldehyde (Sigma) with 2 $\%$ Sucrose (VWR) and permeabilised for $5 \mathrm{~min}$ at room temperature using $0.5 \%$ Triton X-100 (Sigma) in HEPES buffer 20 mM (Sigma) supplemented with $0.3 \mathrm{M}$ saccharose, $50 \mathrm{mM} \mathrm{NaCl}$ (Sigma) and $3 \mathrm{mM} \mathrm{MgCl} 2$ hexahydrate (Scharlab). Then samples were incubated in blocking buffer (1\% BSA) for 15 min at $37^{\circ} \mathrm{C}$, followed by incubation with primary antibodies against differentiation markers (table 7.2). After some washes in 0,5\% Tween 20 (in PBS), samples were sequentially incubated in biotinilated secondary antibodies and Streptavidin-FITC-conjugated tertiary antibodies. Finally, samples were washed and mounted in Vectashield containing DAPI (Vector Laboratories, UK). 
Table 7.2. Antibodies and fluorophores used as hMSCs differentiation markers.

\begin{tabular}{|c|c|c|c|}
\hline Reagent & Company & Reference & Dilution \\
\hline Anti-Desmin & SantaCruz & sc271677 & Dil 1/50 \\
\hline Anti-Myogenin & SantaCruz & sc52903 & Dil 1/50 \\
\hline Anti-MyoD, 58A & SantaCruz & sc32758 & Dil 1/50 \\
\hline Anti-sarcomeric myosin & DSHB & MF-20 & Dil 1/100 \\
\hline Anti-OPN & SantaCruz & sc21742 & Dil 1/50 \\
\hline Anti-OCN & SantaCruz & sc73464 & Dil 1/50 \\
\hline Anti-PPAR $\gamma$ & Insight & sc1984 & Dil 1/50 \\
\hline Anti-LPL & Insight & sc32383 & Dil 1/50 \\
\hline Anti-A-FABP & SantaCruz & sc271529 & Dil 1/50 \\
\hline Anti-Sox9 & Abcam & ab76997 & Dil 1/50 \\
\hline $\begin{array}{l}\text { Biotinilated secondary } \\
\text { antibody }\end{array}$ & Vector & $\begin{array}{l}\text { BA-9200 } \\
\text { BA-1000 }\end{array}$ & Dil 1/50 \\
\hline $\begin{array}{l}\text { Strept-FITC conjugated } \\
\text { antibody }\end{array}$ & Vector & SP-4040 & Dil 1/50 \\
\hline Rhodamine Phalloidin & $\begin{array}{l}\text { Life } \\
\text { Technologies }\end{array}$ & $\mathrm{R} 415$ & Dil 1/100 \\
\hline
\end{tabular}




\subsection{Results and discussion}

\subsubsection{C2C12 differentiation}

C2C12 differentiation was assessed quantifying ALP staining pictures and sarcomeric myosin positive cells. As expected when using growth media, cells on the 2D substrates basically proliferated and reduced differentiation was obtained towards either osteogenic or myogenic lineages (figure 7.2 and 7.3). On the other hand and as discussed in the previous chapter, sandwich culture triggered the formation of long myotubes and promoted myogenesis (figure 7.2). Moreover, sandwich culture hindered the osteogenic differentiation and diminished cell proliferation when compared to the 2D condition (figure 7.2 and 7.3). So, in the case of $\mathrm{C} 2 \mathrm{C} 12$ cells, sandwich culture strictly directs cell differentiation towards the myogenic lineage. Finally, one should notice that cell differentiation was inversely related to cell proliferation (figure 7.3), which can be hypothesised to be a consequence of cell decision between quiescence, differentiation or proliferation. ${ }^{11,12}$ Altogether these results support the strong influence of the sandwich environment in cell fate.
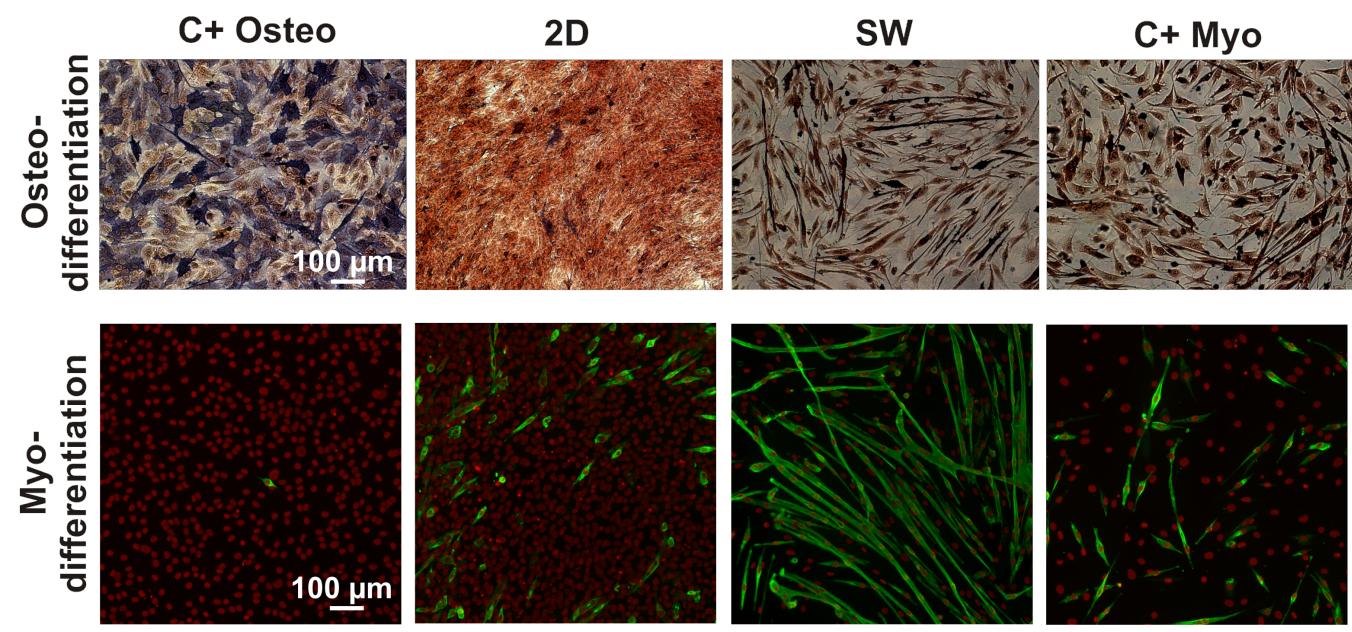

Figure 7.2. C2C12 differentiation when cultured in growth media for 4 days. Alkaline phosphatase staining shows osteodifferentiation in blue and cytoplasm in red. Myodifferentiation is assessed by fluorescence staining of sarcomeric myosin positive cells (green) and cell nuclei (red). 
A

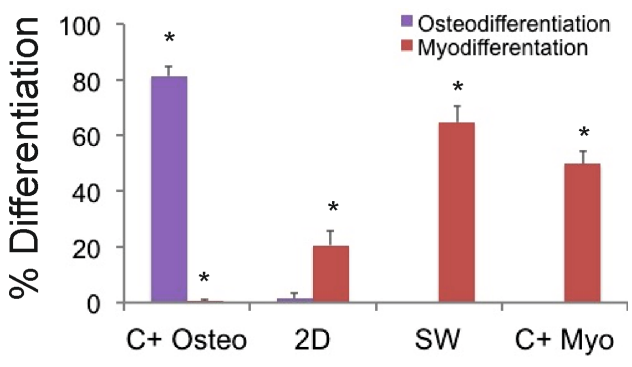

B

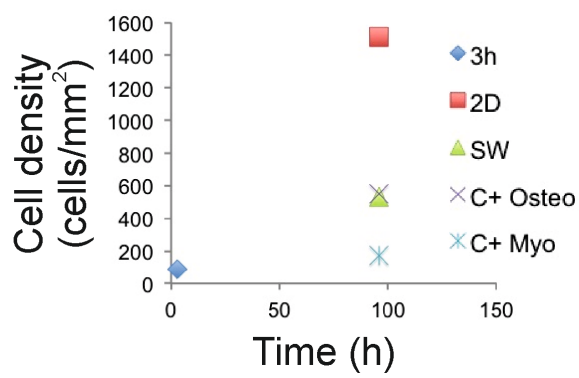

Figure 7.3. $\mathrm{C} 2 \mathrm{C} 12$ differentiation and proliferation after 4 days of culture in growth media. (A) Osteogenic and myogenic differentiation levels for every condition. (B) Cell density after 4 days of culture. Statistically significant differences with the rest of the conditions are indicated with ${ }^{*} \mathrm{P}<0.001$.

\subsection{2 hMSCs differentiation}

Mesenchymal stem cells (MSCs) can be obtained from different sources and be afterwards sorted with different markers in order to obtain a more homogeneous population. This results in a wide spectrum of MSCs that furthermore are formed by sub-populations of different multipotent cells. Hence we studied 4 different human MSCs (hMSCs). Each of them shared the source and the sorting with 2 of the others cell populations (table 7.3). By doing so we want to assess whether the source or the sorting has a mandatory role in cell differentiation. hMSC differentiation under growth media was assessed after 14 days of culture by qPCR and immunofluorescence using specific differentiation markers (detailed in table 7.4 and table 7.2 respectively).

Table 7.3. Mesenchymal stem cells used during this work.

$\begin{gathered}\text { Mesenchymal stem } \\ \text { cells }\end{gathered}$
Source Markers

\begin{tabular}{llc}
\hline $\begin{array}{l}\text { hMSC-AT } \\
\text { (pre-selected) } \\
\text { hMSC-BM } \\
\text { (pre-selected) }\end{array}$ & Adipose tissue & CD31-, CD44+, CD45-, CD105+ \\
hMSC-AT & Bone marrow & CD31-, CD44+, CD45-, CD105+ \\
hMSC-BM & Adipose tissue & Not selected \\
\hline
\end{tabular}


Table 7.4. Summary of the differentiation markers used for qPCR analysis.

\begin{tabular}{ll}
\hline Lineage & Differentiation markers \\
\hline Self-renewal & CD63, ALCAM \\
Adipogenic & PPAR $\gamma$, GLUT-4 \\
Myogenic & MyoD, GATA-4 \\
Osteogenic & OPN, OCN \\
Chondrogenic & SOX9, Collagen II \\
\hline
\end{tabular}

Figure 7.4 A shows cell differentiation of every cell line on the control 2D sample. As can be seen in the graph, the different hMSCs follow a similar trend. However, more variability can be observed for the sandwich culture showing the key role of dimensionality in cell differentiation (figure 7.4 B). These differences do not follow any trend according to the source nor the selection showing the complexity of the process. That is to say, there is not a preferential differentiation towards a unique cell lineage as happened with the $\mathrm{C} 2 \mathrm{C} 12$ cells (figure 7.2 and 7.3). Likewise, when compared to their specific 2D control, different preferential differentiation can be observed for the different hMSCs (see the statistical differences in figure 7.5). 


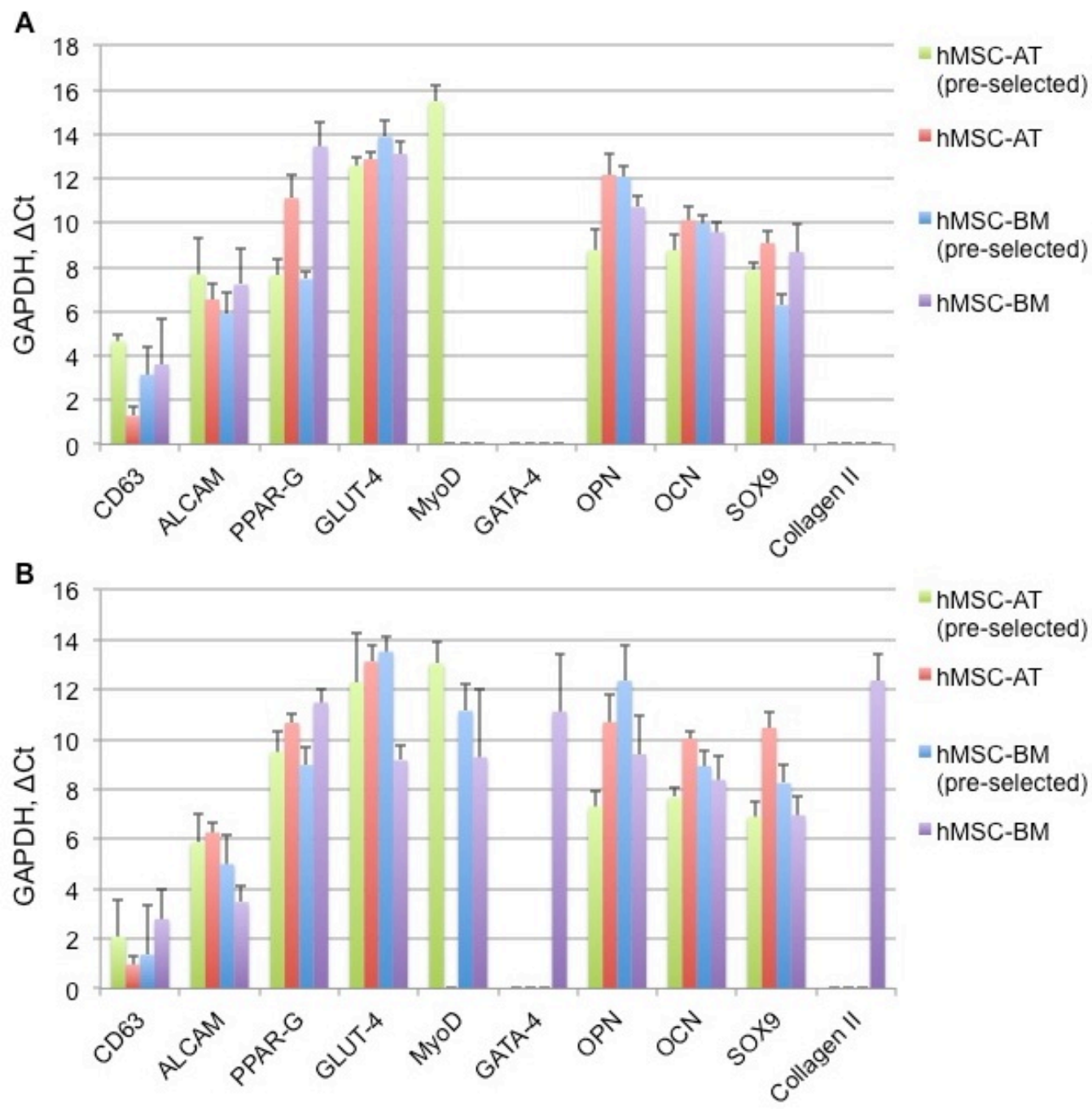

Figure 7.4. hMSCs differentiation after 14 days of culture in growth media as assessed by qPCR. (A) Gene expression profile when cultured on 2D samples (B) and within the sandwich culture. Data is normalized to GAPDH gene expression. Not detected markers adopt a value of 0 . 
In addition, MyoD and GATA-4 markers (myogenic lineage) are more often detected for the SW than the 2D culture suggesting a preferential (but not unique) differentiation towards the myogenic lineage for the SW culture. Hence, multipotent cell differentiation is a complex process highly influenced and tuned by the dimensionality of the environment. These differences observed by qPCR were afterwards corroborated by the immunodetection of differentiation markers (listed in table 7.2). As an example and due to the interest of the differentiation towards the myogenic lineage, sarcomeric myosin was stained for every cell line and is shown in figure 7.6.

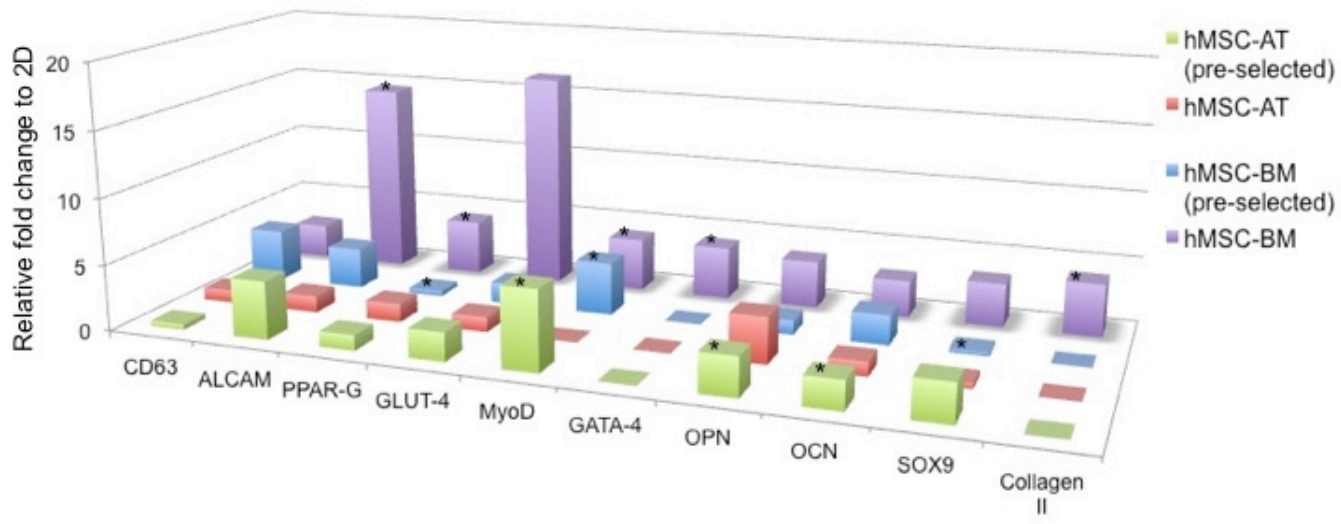

Figure 7.5. hMSCs differentiation after 14 days of sandwich culture in growth media as assessed by qPCR. Data was first normalized to GAPDH gene expression and then to the $2 \mathrm{D}$ condition level that adopts a value close to 1 . Not detected markers adopt a value of 0 . When markers were detected for SW samples but not for 2D samples adopt a random value of 4 since cannot be normalised to the 2D condition. Statistically significant differences with the control 2D are indicated with ${ }^{*} \mathrm{P}<0.05$. 
Additionally and as previously shown, cell density was higher for 2D than for SW samples, which suggests that sandwich culture diminishes cell proliferation over cell differentiation (figure 7.6). This is supported by figure 7.5 since for the SW culture, where there is a decreased in cell proliferation, gene expression of differentiation markers is usually similar or higher than for the 2D condition (where, contrary, cell proliferation is increased). Furthermore, this lower cell density in SW systems resulted in less concentrated RNA samples what hindered the use of the same amount of RNA (200ng) for the qPCR analysis. Despite that, the expression of myogenic markers was more often detected for SW than 2D cultures. Consequently, differentiation towards the myogenic lineage is enhanced within the SW culture when compared to the 2D condition. However hMSC differentiation towards other lineages was also achieved suggesting that the stimulus specifically directing myodifferentiation within the sandwich culture is stronger for $\mathrm{C} 2 \mathrm{C} 12$ cells, likely because of their predifferentiation state since they can only differentiate towards osteogenic and myogenic lineages. 

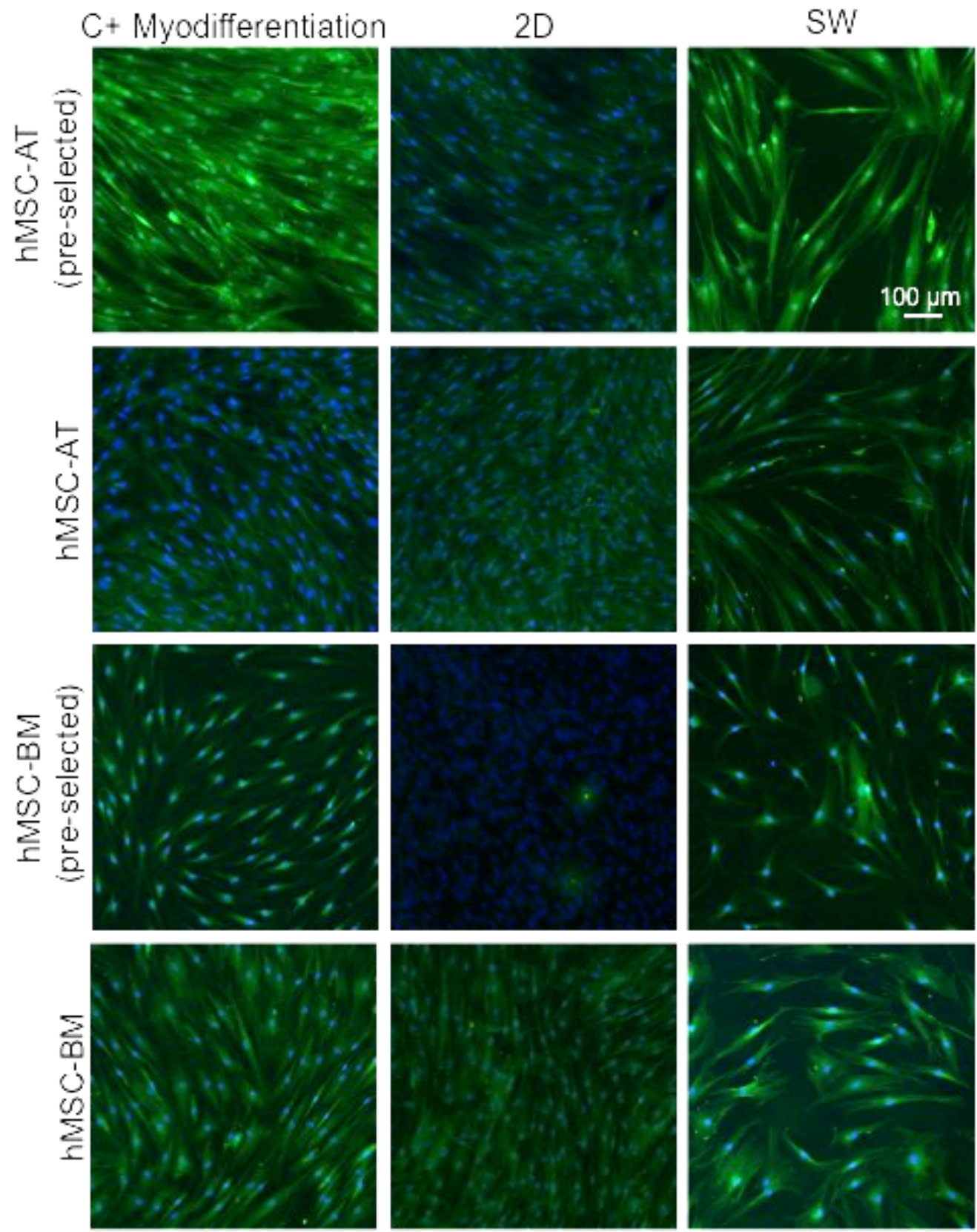

Figure 7.6. Immunofluorescence of hMSCs after 14 days of culture in growth media. Several differentiation markers were tested in order to corroborate the qPCR results. Here it is shown the immunodetection of sarcomeric myosin in green (a myogenic marker) and cell nuclei in blue. For the myodifferentiation control, cells were cultured on 2D samples with DMEM with $2 \%$ FBS, $1 \%$ antibiotic mix and $1 \%$ ITS-X (table 7.1). 


\subsection{Conclusions}

Here we have shown the effect of the sandwich culture in cell differentiation. First we have shown that sandwich culture directs C2C12 differentiation towards the myogenic lineage while hinders the osteogenic differentiation and diminishes cell proliferation. On the other hand, cells cultured on 2D samples basically proliferate and only few of them underwent differentiation. Notwithstanding, this specific induced differentiation towards the myogenic lineage was not observed for hMSCs since also differentiated towards other lineages. Actually, the same sandwich environment triggered different cell response when different hMSCs were studied. This result points out the importance of the microenvironment cell niche in vivo, which highly influence cell fate, and thus the need of mimicking it properly in vitro.

Mesenchymal stem cells are thought to be a key tool in regenerative medicine due to their multipotency potencial. However, we have shown that 4 different hMSCs cultured under the same environment behaved differently. This highlights the need to better understand their cell fate. That is the reason why we are planning further experiments in order to corroborate these results and better characterise the processes involving cell decision. To do so further experiments should be performed including longer times of culture to check if maturation is achieved, testing different environments (by changing the substrates or the protein coatings), metabolomic analysis and the study of the cell signaling pathways induced upon dorsal stimulation. 


\subsection{References}

1. Watt FM, Hogan BL. Out of Eden: stem cells and their niches. Science. 2000;287:1427.

2. Engler AJ, Sen S, Sweeney HL, Discher DE. Matrix elasticity directs stem cell lineage specification. Cell. 2006;126:677.

3. Gilbert PM et al. Substrate elasticity regulates skeletal muscle stem cell self-renewal in culture. Science. 2010;329:1078.

4. Tsimbouri PM et al. Using nanotopography and metabolomics to identify biochemical effectors of multipotency. ACS Nano. 2012;6:10239.

5. McMurray RJ et al. Nanoscale surfaces for the long-term maintenance of mesenchymal stem cell phenotype and multipotency. Nat Mater. 2011;10:637.

6. Murphy WL, McDevitt TC, Engler AJ. Materials as stem cell regulators. Nat Mater. 2014;13:547.

7. Caplan AI. Mesenchymal stem cells. J Orthop Res. 1991;9:641.

8. Le Blanc K, Pittenger M. Mesenchymal stem cells: progress toward promise. Cytotherapy. 2005;7:36.

9. Bruder SP, Fink DJ, Caplan AI. Mesenchymal stem cells in bone development, bone repair, and skeletal regeneration therapy. J Cell Biochem. 1994;56:283.

10. Caplan AI. Adult mesenchymal stem cells for tissue engineering versus regenerative medicine. J Cell Physiol. 2007;213:341.

11. Xia K, Xue H, Dong D, Zhu S, Wang J, Zhang Q, Hou L, Chen H, Tao R, Huang Z, Fu Z, Chen YG, Han JD. Identification of the proliferation/differentiation switch in the cellular network of multicellular organisms. PLoS Comput Biol. 2006;2(11):e145.

12. Hardwick LJ, Philpott A. Nervous decision-making: to divide or differentiate. Trends Genet. 2014;30(6):254-61. 


\section{Conclusions}



This thesis deals with the effect of dimensionality in cell fate (2D vs 3D). To do so, this thesis introduces the use of the sandwich-like culture as an approach to 3D cultures. Cells cultured within this system are dorsally and ventrally stimulated upon cell/material interactions. Consequently, sandwich culture is a versatile tool that allows the study of cell behaviour under well-controlled conditions, including different material systems and protein coatings. Hence this thesis presents the sandwich-culture based technology and uses it to investigate the effect of different ventral and dorsal conditions on cell fate including morfology, adhesion, cell signalling, proliferation, migration and diferentiation.

The main findings extracted from this thesis are presented below.

\section{Sandwich culture is a versatile approach to 3D cultures.}

We have introduced a novel technology to investigate the role of dimensionality in cell behaviour. It is based on the simultaneous stimulation of dorsal and ventral receptors and it is highly versatile to study different material properties and ECM inputs.

\section{Cell morphology and adhesion are highly influenced by the sandwich culture conditions.}

Throughout the thesis, cell morphology and adhesion have been shown to depend on the ventral and dorsal stimuli pointing out a competition between both stimuli where timing, topological cues and ECM reorganization play a key role. 
3. Sandwich culture triggers changes in cell signalling and proliferation.

Dorsal stimuli provided by the sandwich-like culture alter the intracellular signalling in NIH3T3 fibroblasts and $\mathrm{C} 2 \mathrm{C} 12$ myoblast by decreasing the level of FAK phosphorylation ( $\mathrm{pFAK} / \mathrm{FAK}$ ratio). Additionally, cell proliferation is diminished compared to the equivalent 2D culture.

\section{Sandwich culture alters cell migration.}

Cell migration and morphology of L929 fibroblasts were altered within the sandwich culture. Strikingly, different cell seeding procedures lead to different cell migration rates and morphology (highly elongated or not). These results suggest that cell-cell contact is an important factor to consider. Furthermore, cell migration rates are related to the nature of the ventral and dorsal stimulation. So changing the ventral or dorsal protein/material interface input results in a change in cell migration.

\section{Sandwich culture enhances ECM reorganisation.}

Culture of cells within sandwich systems increases cell-mediated reorganisation of the (ventral) FN coating into FN fibrils as has been seen in other 3D cultures. This process relies on the mechanical stimuli on dorsal receptors and cytoskeleton stability (since contractility inhibitors hinder the process). 
6. The dorsal substrate triggers changes in cell fate not only by the biological stimuli but also by the mechanical input.

Cells overlaid with a non-biologically active dorsal substrate undergo similar changes as if protein coated substrates were used -and different to the 2D condition- in terms of ECM reorganisation, cell morphology, cell migration and cell differentiation. These results point out the importance of the physical properties of the dorsal and ventral stimuli to mimic in vivo environments.

\section{Sandwich culture directs $\mathrm{C} 2 \mathrm{C} 12$ cells differentiation.}

Sandwich culture directs $\mathrm{C} 2 \mathrm{C} 12$ cells differentiation towards the myogenic lineage. In addition, the stimuli coming from the dorsal substrate can alter the differentiation rate. These findings indicate the potential to control cell commitment through the material/protein properties of the sandwich environment.

\section{Sandwich culture alters hMSCs differentiation.}

The differentiation of four different hMSC lines cultured on 2D substrates and within sandwich systems was assessed. Results show that differentiation is altered when compared to the 2D condition, but also between the different cell lines. This result points out the importance of the relationship between cell source and 3D microenvironment cell niche in vivo, and thus the need of mimicking it properly in vitro. 
9. Cells within the sandwich culture share similarities with cells

\section{cultured in 3D systems.}

Cells cultured under the sandwich system undergo similar changes in cell morphology, adhesion, signalling, migration and differentiation as cells cultured in 3D systems. As an example, sandwich culture triggered an increase expression of $\alpha_{5}$ integrin subunit in fibroblasts and decrease of pFAK/FAK ratio in fibroblasts and myoblasts, similarly as seen in other 3D cultures. Cell morphology was further correlated with the ability of cells to reorganise the ECM, similarly as happens in 3D hydrogels (degradable vs non-degradable). 




\section{Curriculum Vitae}

\section{Education}

2010-2014 Ph.D. candidate in Biotechnology

In Centre for Biomaterials and Tissue Engineering (CBIT), at Universitat Politècnica de València (Spain)

FPU research grant from Spanish Ministry (AP2009-3626)

Thesis title: Sandwich-like systems to engineer the cellular microenvironment

Supervisors: Dr. Patricia Rico \& Prof. Manuel Salmerón-Sánchez

2009-2010 M.Sc. in Biomedical Biotechnology

at Universitat Politècnica de València (Spain)

Project performed in Centre for Biomaterials and Tissue Engineering (CBIT), at Universitat Politècnica de València (Spain)

Project title: Cellular interaction with superhydrophobic substrates

Supervisors: Dr. Patricia Rico \& Prof. Manuel Salmerón Sánchez

\section{Internships during the PhD}

2013-2014 University of Glasgow (UK)

Supervisor: Prof. Matthew Dalby (Institute of Molecular, Cell and Systems Biology)

2012 Martin-Luther-Universität Halle-Wittenberg (Germany)

Short-term research grant from DAAD (German Academic Exchange Service)

Supervisor: Prof. Thomas Groth (Head of Biomedical Materials Group) 


\section{Publications}

8- Cell migration within confined sandwich-like nanoenvironments José Ballester-Beltrán, Myriam Lebourg, Patricia Rico, Manuel SalmerónSánchez Nanomedicine (submitted)

7- Fibronectin-matrix sandwich-like microenvironments to manipulate cell fate

J Ballester-Beltrán, D Moratal, M Lebourg, M Salmerón-Sánchez

Biomaterials Science. 2(3) pp. 381-389 (2014)

6- Robust fabrication of electrospun-like polymer mats to direct cell behaviour

J Ballester-Beltrán, M Lebourg, H Capella, A Díaz Lantada, M SalmerónSánchez

Biofabrication. 6(3) p. 035009 (2014)

5- Dorsal and ventral stimuli in sandwich-like microenvironments. Effect on cell differentiation

José Ballester-Beltrán, Myriam Lebourg, Manuel Salmerón-Sánchez

Biotechnology and bioengineering. 110(11) pp. 3048-3058 (2013)

4- Dorsal and Ventral Stimuli in Cell-Material Interactions: Effect on Cell Morphology

José Ballester-Beltrán, Myriam Lebourg, Patricia Rico, Manuel SalmerónSánchez

Biointerphases. 7(1-4) pp. 1-9 (2012)

3- Effect of topological cues on material-driven fibronectin fibrillogenesis and cell differentiation José Ballester-Beltrán, Marco Cantini, Myriam Lebourg, Patricia Rico, David Moratal, Andrés J García, Manuel Salmerón-Sánchez Journal of Materials Science: Materials in Medicine. 23(1) pp. 195-204 (2012)

2- Role of superhydrophobicity in the biological activity of fibronectin at the cell-material interface José Ballester-Beltrán, Patricia Rico, David Moratal, Wenlong Song, João F Mano, Manuel Salmerón-Sánchez

Soft Matter. 7(22) pp. 10803-10811 (2011) 
1- Role of surface chemistry in protein remodeling at the cell-material interface

Virginia Llopis-Hernández, Patricia Rico, José Ballester-Beltrán, David Moratal, Manuel Salmerón-Sánchez

PloS one. 6(5) e19610 (2011)

\section{Conferences}

$41^{\text {st }}$ Annual Congress of the European Society for Artificial Organs (ESAO) Oral communication (2014)

Cell behaviour in sandwich-like cultures

J. Ballester-Beltrán, M. Lebourg, M. Salmerón-Sánchez

Signal Transduction by Engineered Extracellular Matrices (Gordon Research Conferences)

Poster (2014)

Human mesenchymal stem cell differentiation within sandwich environments

J. Ballester-Beltrán, E.V. Alakpa, M. Lebourg, M.J. Dalby and M. SalmerónSánchez

$25^{\text {th }}$ European Conference on Biomaterials

Oral communication (2013)

Sandwich-like culture: the missing link between $2 D$ and $3 D$ environments

J. Ballester-Beltrán, M. Lebourg, M. Salmerón-Sánchez

$2^{\text {nd }}$ Interrogations at the Biointerface Advanced Summer School

Poster (2012)

Role of dorsal interaction on cell differentiation

J. Ballester-Beltrán, M. Lebourg, M. Salmerón-Sánchez

24th European Conference on Biomaterials

Poster (2011)

Influence of Surface Chemistry on Cell Proteolytic Activity at the Material Interface

V.L. Hernández, P.Rico, J. Ballester-Beltrán, D. Moratal, M. Salmerón-Sánchez 


\section{$13^{\text {th }}$ European Polymer Congress}

Poster (2011)

Matrix Protein Dynamics on Polymer Surfaces

C. González-García, P. Rico, M. Cantini, J. Ballester-Beltrán, V. LlopisHernández, M. Salmerón-Sánchez

Tissue Engineering \& Regenerative Medicine International Society Poster (2011)

Altered fibronectin adsorption and cell adhesion on superhydrophobic polystyrene

J. Ballester-Beltrán, P. Rico, W. Song, D. Moratal, J.F. Mano and M. SalmerónSánchez 

